\title{
Die fisika van motorbotsings en padverkeersveiligheid
}

\author{
R. Saayman \\ Departement Fisika, Universiteit van Stellenbosch, Stellenbosch 7600
}

Onwang 16 November 1990; aanvaar $16 \mathrm{Mei} 199 \mathrm{l}$

\begin{abstract}
UITTREKSEL
'n Oorsig word gegee van die interafhanklike fisiese veranderlikes en wetmatighede wat op die spel is tydens die beweging van 'n padvoertuig in ' $n$ verkeersituasie, en die toepassing daarvan om werklike botsings te ontleed en te voorkom. Ter inleiding word die jongste RSA-botsingstatistiek en navorsingsresultate oor bydraende faktore en tipes botsings wat voorkom, aangebied. Dan word spoed as 'n faktor ondersoek met ' $n$ bespreking van die relatiewe snelheid tussen voertuie; stilhouvermoë en veilige volgafstande; die besluit om by ' $n$ veranderende verkeerslig te stop of oor te ry; asook spoed-voor-botsingberamings uit wielsleepmerke en projektielspronge. Derdens word voertuigstabiliteit bespreek met toepassings van gewigsverplasing tydens skielike versnellings; verklarings vir uitgly en omslaan om 'n draai in die pad; asook vragverskuiwing. Veiligheidswenke word aangebied. Die impulsmomentum- en werkenergiebeginsels word vervolgens op sentriese botsings (slegs translasie), asook eksentriese botsings (sowel translasie as rotasie) toegepas, sodat botsingstye en -versnellings bereken kan word. 'n Voorbeeld van hoe 'n reghoekige botsing by 'n straatkruising geherkonstrueer en ontleed kan word, om die moontlike oorsaak en regsaanspreeklikheid te kan aandui, word behandel. In die sesde afdeling word permanente vervorming as gevolg van botsing, voertuigskade en passasiersbeserings aan die hand van gesimuleerde trompop botsings teen soliede versperrings bespreek. Ten slotte word kortliks verwys na 'n paar tegnologiese ontwikkelings waardeur die voertuig, pad en bestuurder veiliger en in groter harmonie kan saamwerk.
\end{abstract}

\section{ABSTRACT}

\section{The physics of automobile collisions and road traffic safety}

A survey is given of the interdependent physical variables and principles relevant to the motion of a road vehicle in a traffic situation and its application to analyse and prevent actual collisions. As introduction recent RSA collision statistics and research results on contributing factors and types of collisions which occur, are presented. Then speed as cause is investigated with a discussion of the relative velocity between vehicles; stopping ability and safe following distances; the decision to stop or not at a changing traffic light; as well as estimations of the speed before collisions from wheel skidding marks and projectile flips and vaults. Thirdly vehicle stability is discussed with applications of weight displacement during sudden accelerations; explanations for skidding out of and turning over on a road bend; as well as load displacement. Safety hints are presented. Subsequently the impulse-momentum and work-energy principles are applied to centric collisions (translation only), as well as eccentric collisions (both translation and rotation) so that collision periods and accelerations can be calculated. An example of the reconstruction and analysis of a right-angled collision at a street crossing is treated, to determine the possible cause and legal liability. In the sixth section permanent deformation due to collisions, vehicle damage and occupant injuries are discussed with regard to simulated head on collisions with a rigid barrier. In conclusion brief reference is made to a few technological developments which improve the harmonious and safer interaction between vehicle, road and driver.

\section{INLEIDING}

Die mens se afhanklikheid van die motor as vervoermiddel neem steeds toe. Die gepaardgaande styging in die aantal voertuie en bestuurders op die paaie verhoog die risiko van motorbotsings. Dit veroorsaak onberekenbare koste ten opsigte van materiële en tydverliese, lyding weens beserings en smart as gevolg van sterftes.

Die slagting op die Suid-Afrikaanse paaie is welbekend, soos tabel 1 ook kwantitatief aandui, en van die hoogste in die wêreld. Die padgebruik behels tans sowat 5,7 miljoen voertuie (waarvan $57 \%$ passasiersmotors) wat gemiddeld $17000 \mathrm{~km}$ jaarliks aflê met 'n $13 \%$ (16\% vir motors) botsingswaarskynlikheid. Die sterftekoers oor die afgelope veertig jaar beloop $17,6 \pm 6,8$ per $10^{8}$ voertuig-km afgelê, wat hoër as enige van die ontwikkelde lande is (vergelyk byvoorbeeld met $1-3$ vir die VSA, Brittanje en Duitsland), alhoewel laer as dié van ander Afrikalande. ${ }^{1.2} \mathrm{Dit}$ kos die RSA jaarliks meer as vyf biljoen rand. Noodlottige verkeersbotsings is ook die dominante $(30 \%)$ oorsaak van sterftes onder jong mense in die ouderdomsgroep 6 -34 jaar. $^{3}$

Die oorsake van motorbotsings is ' $\mathrm{n}$ ingewikkelde samespel van drie hooffaktore (kyk tabel 2), naamlik die voertuig wat na beraming, 5 'n skrale $2,4 \%$ bydra, die pad en omgewing wat vir 7,0\% verantwoordelik is en die bestuurder of padgebruiker wat ' $n$ dominante $90,6 \%$ sleutelrol speel. Laasgenoemde bevinding verklaar voorkeurgebruik van die term (verkeers)botsing bo (pad)ongeluk, soos aanbeveel deur die NVVR. ${ }^{6}$

Fisies word ' $n$ botsing beskryf as ' $n$ situasie wanneer twee of meer voorwerpe neig om dieselfde posisie in die ruimte op dieselfde tydstip te beset. Wetenskaplike tipering van padvoertuigbotsings word in tabel 3 gegee. Daar word vervolgens aandag gegee aan die interafhanklike fisiese veranderlikes en wetmatighede wat ' $n$ rol speel tydens die beweging van ' $n$ motor in 'n verkeersituasie. Daar word ook aangedui hoedat sodanige kennis toegepas kan word om praktiese botsingsituasies te ontleed en moontlik te voorkom. 
TABEL 1

RSA-botsingstatistiek vir $1989^{\text {a) }}$

\begin{tabular}{|c|c|c|c|c|c|c|c|}
\hline \multirow[t]{2}{*}{ Graad } & \multicolumn{3}{|c|}{ Getal botsings } & \multirow{2}{*}{$\begin{array}{c}\text { Eenheids- } \\
\text { koste }^{\mathrm{f}} \\
\mathrm{x} 10^{2} \mathrm{R}\end{array}$} & \multicolumn{3}{|c|}{ Getal ongevalle } \\
\hline & $\times 10^{3}$ & $\%$ & $/ 10^{\mathrm{s}} \mathrm{km}^{\mathrm{c})}$ & & $\times 10^{3}$ & $\%$ & $/ 10^{8} \mathrm{~km}^{\mathrm{e}}$ \\
\hline Noodlottigb) & 9 & 2 & 9 & 197 & 11 & 9 & 11 \\
\hline Ernstig() & 21 & 5 & 21 & 53 & 32 & 25 & 26 \\
\hline Geringd) & 59 & 14 & 60 & 18 & 84 & 66 & 86 \\
\hline Slegs skade & 346 & 79 & 354 & 4 & - & - & - \\
\hline Totaal & 435 & 100 & 445 & $\left.124^{g}\right)$ & 127 & 100 & 130 \\
\hline
\end{tabular}

(a) Saamgestel uit gegewens goedgunstiglik deur die Sentrale Statistiekdiens (SSD), Nasionale Instituut vir Vervoer- en Padnavorsing (NIVP) van die WNNR, en die Nasionale Verkeersveiligheidsraad (NVVR) verskaf.

(b) Minstens een persoon sterf as gevolg van die botsing, onmiddeilik of binne ses dae daarna.

(c) Minstens een persoon doen beserings op wat hospitalisasie vereis, soos frakture, vergruising, harsingskudding, inwendige beserings, ernstige snye en ernstige skok, maar geen noodlottige gevalle kom voor nie.

(d) Minstens een persoon doen beserings soos snye, kneusplekke en verstuiting op, wat nie altyd hospitalisasie van minstens een dag vereis nie.

(e) Botsings- en ongevallekoerse is bereken uit 'n beraamde totaal van $97734 \times 10^{6}$ voertuig-km afgelê.

(f) Faktore soos eiendomskade (55\%), verlies van uitset (34\%), pyn en lyding, hospitalisasie, medikasie, begrafnis, wetlike aspekte, administrasie, tydverlies en polisiebetrokkenheid is in ag geneem, maar nie emosionele trauma nie.

(g) Gemiddelde koste per botsing; die totale koste vir alle botsings beloop R5 $386 \times 10^{6}$.

TABEL 2

Bydraende faktore tot padvoertuigbotsings ${ }^{4}$

\section{Faktor}

Menslike bestuurder:

Onoplettend- en onbedagsaamheid

Roekelose en nalatige bestuur

Spoed te hoog vir toestand

Te naby volgafstand

Ander verkeersoortredings

\section{Persentasie}

Onbekwaamheid vir taak

Onder invloed van alkohol of dwelms

Fisiologiese faktore (moeg of siek)

Emosionele faktore (stres of depressie)

1,7

11,1

7,5

3,2

1,4

0,7

Pad en omgewing:

Die weer (reën, mis, wind, ens.)

Geometriese padontwerp

Omgewing (swak verlig, padtekens, uitsig)

Voertuig:

Defekte en onpadwaardigheid

\section{SPOED AS FAKTOR}

\subsection{Relatiewe snelheid}

Alle beweging is relatief van aard ten opsigte van 'n bepaalde waarnemer of gespesifiseerde verwysingspunt. Die absolute snelheid van 'n enkele voertuig is dit wat nor-
TABEL 3

Klassifikasie van botsings ${ }^{4}$

\begin{tabular}{|lc|}
\hline Tipe & Persentasie \\
Dieselfde rigting & 19,6 \\
Teenoorgestelde rigting & 30,8 \\
Stilstaande voorwerp & 11,4 \\
Bewegende voorwerp & 0,3 \\
Voetganger & 13,3 \\
Enkelvoertuig & 19,9 \\
Ander & $\underline{4,7}$ \\
& $\underline{100,0}$ \\
\hline
\end{tabular}

maalweg relatief tot die aarde of pad aangedui word. In die geval van navigasie deur verkeer, onderskepping, ontmoeting of botsing tussen twee of meer bewegende voertuie (genommer 1 en 2), is die snelheid van die een (sê 1) relatief tot die ander (sê 2 in rus), egter van belang en word verkry uit die vektoriële verskil.

$$
\vec{v}_{12}=\vec{v}_{1}-\vec{v}_{2}=-\vec{v}_{21}
$$

Dit kan grafies deur noukeurige konstruksie en meting volgens skaal bepaal word, of trigonometries bereken word met behulp van formules vir die

$$
\begin{array}{lc}
\text { grootte: } & v_{12}=\left(v_{1}^{2}+v_{2}^{2}-2 v_{1} v_{2} \cos \theta\right)^{1 / 2}, \\
\text { en rigting: } & \phi=\sin ^{-1}\left(\frac{v_{2}}{v_{12}} \sin \theta\right),
\end{array}
$$

as funksies van die hoek, $\theta$, tussen die voertuigbewegingsrigtings (kyk figure l(c) en (d)). 


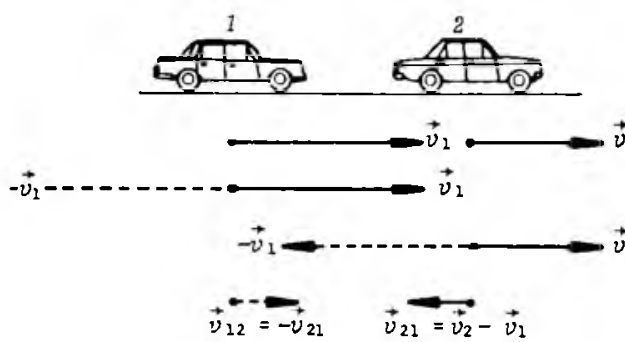

(a) In dieselfde rigting $\left(\theta=0^{\circ}\right)$

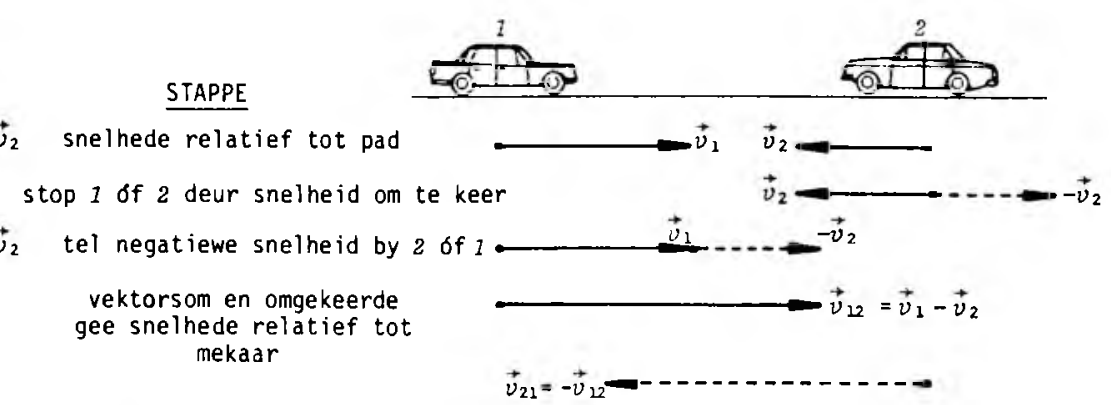

(b) In teenoorgestelde rigtings $\left(\theta=180^{\circ}\right)$
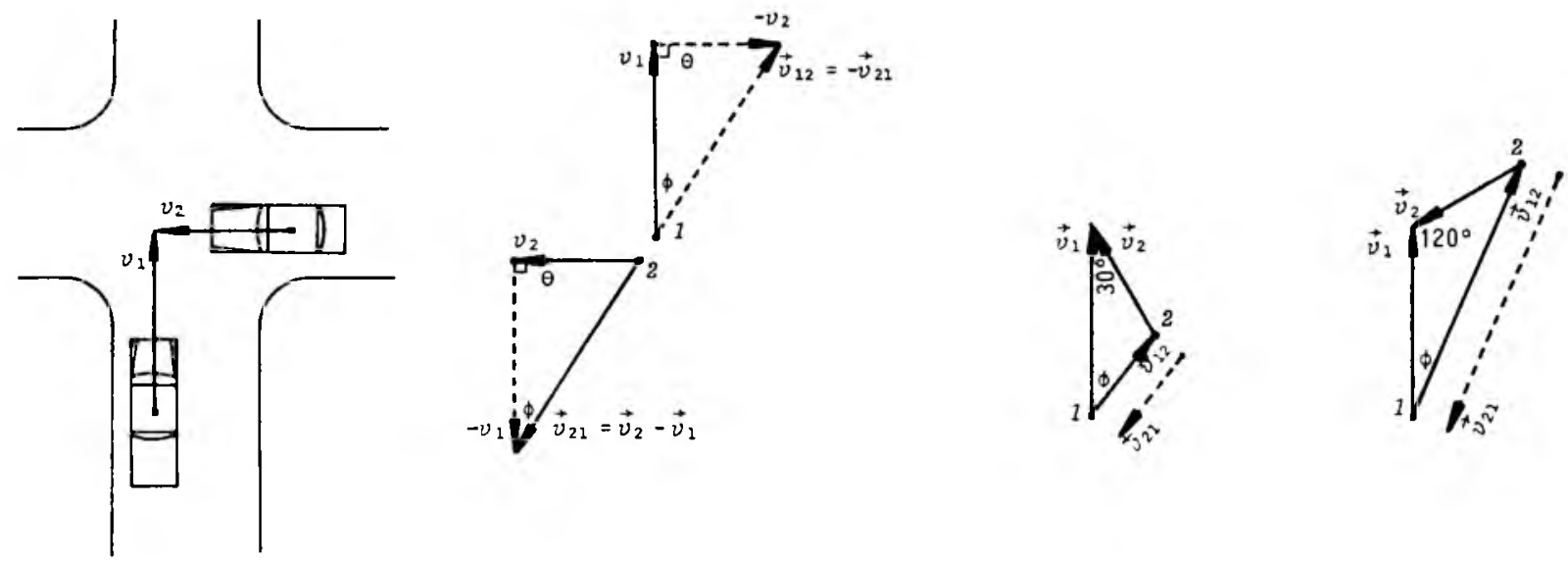

(c) Reghoekig by $n$ kruising $\left(\theta=90^{\circ}\right)$

(d) Skuinshoekig $\left(0^{\circ}<\theta<180^{\circ}\right)$

FIGUUR I: Bepaling van die relatiewe snelhede van twee bewegende motors.

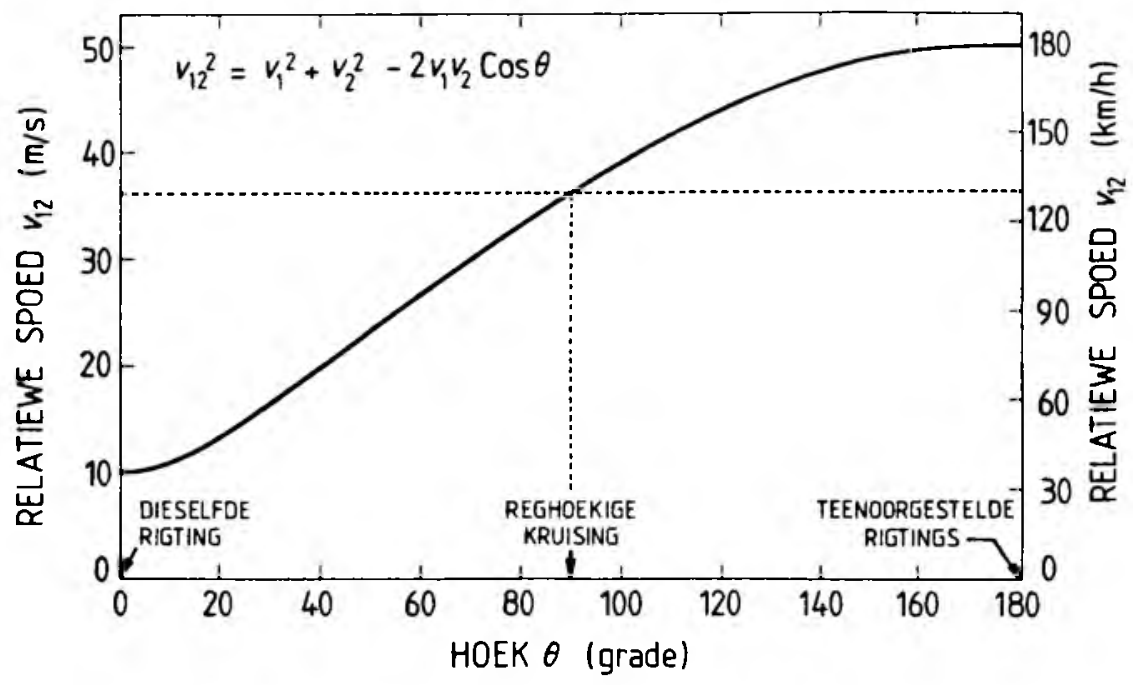

FIGUUR 2: Die relatiewe spoed, $v_{12}$, as funksie van die rigting (hoek $\theta$ ) vir absolute spoede $v_{1}=30 \mathrm{~m} / \mathrm{s}$ en $v_{2}=20 \mathrm{~m} / \mathrm{s}$.

Figuur 1(a)-(d) vergelyk die relatiewe snelheidsvektore vir vier tiperende gevalle van hoek, $\theta$, tussen voertuie met absolute spoede, $v_{1}=30 \mathrm{~m} / \mathrm{s}(108 \mathrm{~km} / \mathrm{h})$ en $v_{2}=20 \mathrm{~m} / \mathrm{s}$ $(72 \mathrm{~km} / \mathrm{h})$, en figuur 2 stel hulle relatiewe spoed grafies as 'n kontinue funksie van hoek $\theta$ voor. Die relatiewe snelheidsvektor, $\vec{v}_{21}$, dui die skynbare rigting aan waarin voertuig 2 beweeg vir ' $n$ waarnemer in rus by voertuig 1 . In figuur I(a), byvoorbeeld, beweeg albei motors werklik na regs vir 'n waarnemer op die pad, maar vir 'n waarnemer in voertuig 1 lyk dit asof 2 na links naderkom. Indien hulle relatiewe snelheidsvektor langs die verbindingslyn tussen hulle oombliklike posisies geleë is, sal die twee voertuie op dieselfde tydstip by dieselfde posisie aankom en sal dus bots, tensy 'n vermydingsaksie uitgevoer word, soos 'n spoed- en/of rigtingverandering. Sowel die momentum, $\vec{p}=\mathrm{m} \vec{v}$, as bewegingsenergie, $\mathrm{E}_{\mathrm{k}}=\frac{1}{2} m v^{2}$, van 'n voertuig met massa $m$ wat tydens 'n botsing geabsorbeer word. is spoedafhanklik, naamlik lineêr en kwadraties respektiewelik. Die groottes van die relatiewe snelheidsvektore in figure 1 en 2 illustreer dus die groter gevaar (skade en ongevalle) van 'n kop teen kop botsing $\left(\theta=180^{\circ}, v_{12}=\right.$ $50 \mathrm{~m} / \mathrm{s}=180 \mathrm{~km} / \mathrm{h}$ ) bo dié van 'n botsing by 'n reghoekige kruising $\left(\theta=90^{\circ}, v_{12}=36 \mathrm{~m} / \mathrm{s}=130 \mathrm{~km} / \mathrm{h}\right)$. Laasgenoemde is weer gevaarliker as 'n kop teen stert botsing $\left(\theta=0^{\circ}, v_{12}=10 \mathrm{~m} / \mathrm{s}=36 \mathrm{~km} / \mathrm{h}\right)$ weens 'n te kort volgafstand.

Spoed op sigself veroorsaak nie botsings nie, maar wel die feilbare menslike beheer daaroor. Onvermoë of versuim om die spoed by heersende bestuurder-, pad-, omgewingen voertuigomstandighede aan te pas, is 'n dominante 
bydraende faktor (kyk tabel 2) wat die ernstigheidsgraad van botsings sterk beinvloed. ${ }^{1.7}$ So byvoorbeeld het te kort volgafstande wat die aanbevole tweesekondereël verontagsaam, 29\% van alle botsings in die RSA gedurende 1987 uitgemaak. ${ }^{8-11}$

\subsection{Stilhouvermoë en volgafstande}

'n Lewensbelangrike veiligheidsaspek van padvoertuigbestuur is die vermoë om betyds op gevaartckens te reageer en die voertuig in 'n noodsituasie vinnig tot stilstand te bring. Stilhouvermoë word deur sowel die reaksievermö̈ van die menslike bestuurder as die meganiese remdoeltreffendheid van die voertuig op die pad bepaal. Bestuurderreaksietyd, $t_{r}$, is die tydsverloop vanaf waarneming van die gevaar, gevolg deur die besef daarvan en wilsbesluit om stil te hou, totdat die voet van die versnellerpedaal verwyder en rem getrap word. Dit wissel van persoon tot persoon van 'n halwe tot twee sekondes, met een sekonde as 'n aanvaarbare gemiddelde. ${ }^{10}$ Remtoetstye, $t_{b}$, om ' $n$ beheerde noodstop vanaf spoed $v=100 \mathrm{~km} / \mathrm{h}$ tot rus op 'n gelyk en droë pad uit te voer, wissel van 3,0 tot 5,17 s met 'n gemiddelde 3,80 s vir 81 nuwe passasiersmotors deur die tydskrif Car gespesifiseer. ${ }^{\text {" }}$ Dit impliseer 'n gemiddelde remvertraging, $a_{b}=\frac{v}{t_{b}}=7,31 \mathrm{~m} / \mathrm{s}^{2}$, oftewel $75 \%$ remdoeltreffendheid op 'n standaard waarvolgens volle remkrag aan die voertuiggewig gelyk gestel word. ${ }^{2}$

Die totale stilhou-afstande vir verskillende togspoede word uit die som van die reaksie- en remafstande bereken volgens

$$
s=s_{r}+s_{b}=v t_{r}+\frac{v^{2}}{2 a_{b}},
$$

en net so die totale stilhoutyd uit

$$
t=t_{r}+t_{h}=t_{r}+\frac{v}{a_{b}},
$$

met grafiese voorstelling in figuur 3 . Die paraboliese en reglynige verloop vertoon respektiewelik duidelik die kwadratiese en lineêre toename van die stilhou-afstand en -tyd met spoedtoename. So byvoorbeeld sal verdubbeling van die motorspoed van 60 tot $120 \mathrm{~km} / \mathrm{h}$, die stilhou-afstand met 'n faktor drie verleng, oftewel van 8,5 tot 26 gemiddelde motorlengtes, $L=4,22 \mathrm{~m}$ (tabel 1.2, Saayman ${ }^{13}$ ), terwyl die stilhoutyd met $70 \%$ toeneem. Bestuurderaanpassing van die voertuigspoed by heersende omstandighede, soos veilige volgafstande in druk verkeer, is dus baie belangrik. Gestel as voorbeeld bestuurder A word deur bestuurder B na een sekonde gevolg, beide teen 'n spoed van $100 \mathrm{~km} / \mathrm{h}$, wanneer 'n voetganger voor A oor die pad hardloop. Uit formule 4 word die volg-, rem- en totale stilhou-afstande by genoemde spoed respektiewelik as 27,8; 52,8 en $80,6 \mathrm{~m}$ bereken. Indien A en B gelyktydig en met dieselfde $t_{r}=1 \mathrm{~s}$ reageer, sal daar geen kop teen stert botsing plaasvind nie, maar indien $B$ eers op A se remligte reageer, soos dikwels in die praktyk gebeur, is 'n botsing moontlik $(27,8+52,8 \mathrm{~m}=80,6 \mathrm{~m})$. Verdubbeling van genoemde volgtyd tot $t_{r}=2 \mathrm{~s}$ soos aanbeveel deur die NVVR, sal B egter 'n veilige "leefruimte" van ongeveer 6,5 gemiddelde motorlengtes laat.

Die voorstellings in figuur 3 verteenwoordig slegs minimum teoretiese waardes onder ideale omstandighede. Die $\mathrm{krag}$ om ' $\mathrm{n}$ voertuig tot stilstand te bring, ontstaan uit wisselwerking tussen die bestuurder, voertuig en pad, wat op ingewikkelde wyse deur verskeie interafhanklike empiriese faktore beïnvloed word. Fisiologiese bestuurderfaktore soos

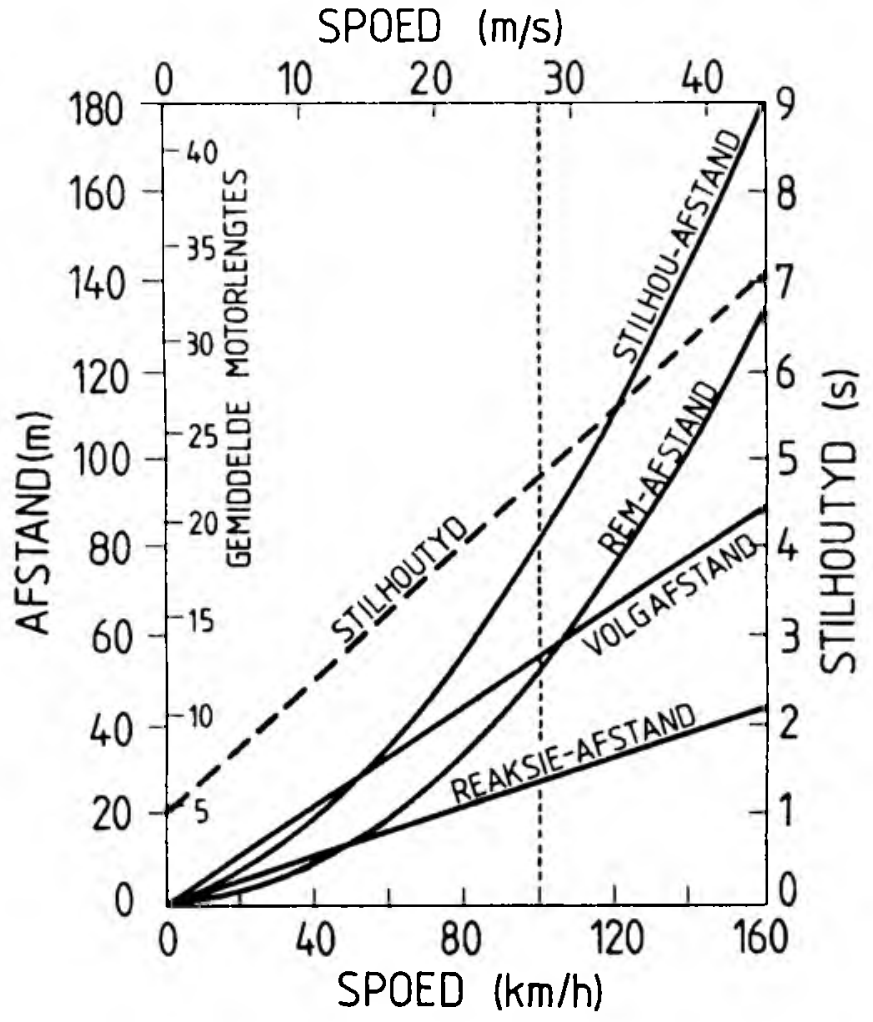

FIGUUR 3: Grafieke van minimum stilhou-afstande uit die som van die reaksie-afstande met $t_{r}=1 \mathrm{~s}$ en noodremafstande met $a_{r}=7,31 \mathrm{~m} / \mathrm{s}^{2} ; N V V R$ aanbevole volgafstande met $t_{v}=2 s$ (linkerkantse skaal); asook stilhoutye (regterkantse skaal) as funksies van die togspoed vir 'n gemiddelde passasiersmotor.

vermoeidheid, pad- en spoedhipnose, verdeelde aandag, alkohol-en dwelmgebruik, ooggebreke en ouderdom sal die reaksietyd verleng. Verslete en foutiewe bande en remme, groter voertuigbelading, swak en ongelyk paaie en nat weer verminder die remdoeltreffendheid. Gesamentlik laat hierdie faktore die stilhou-afstande en -tye aansienlik toeneem, d.w.s. steiler grafies verloop as in figuur 3 .

\subsection{Die verkeersligdilemma}

Elke bestuurder word dikwels by 'n straatkruising met die besluit gekonfronteer om stil te hou of oor te ry wanneer die verkeerslig van groen na geel oorskakel. ${ }^{1416}$ 'n Verkeerde besluit is potensieel gevaarlik - dit kan 'n botsing en/of 'n verkeersboete tot gevolg hê! Daar kan 'n sogenaamde "dilemmasone" ontstaan, naamlik 'n gebied waarin die motor te naby is om betyds voor die stopstreep stil te hou, maar ook nog te ver is om die kruising betyds oor te steek voordat die lig na rooi verander. Dit is afhanklik van verskeie faktore: die oorgangsligtyd, $t$, (3,5 tot 4,0 s gemeet te Stellenbosch); die bestuurder se reaksietyd, $t_{r}$ (gemiddeld $1 \mathrm{~s}$, kyk na afd. 2.2); die versnelling tydens aandrywing, $a$ (gemiddeld $1,5 \mathrm{~m} / \mathrm{s}^{2}$ oor die $40-60 \mathrm{~km} / \mathrm{h}$ interval, tabel 3, Saayman ${ }^{13}$ ) en remming, $a_{b}$ (gemiddeld $4 \mathrm{~m} / \mathrm{s}^{2}$ norwaalweg ${ }^{15,} 16$ tot $7,31 \mathrm{~m} / \mathrm{s}^{2}$ tydens 'n noodstop, afd. 2.2); die naderingspoed, $v$, en -afstand, $d$, vanaf die besluitpunt tot by die stopstreep; die motorlengte, $L$ (gemiddeld 4,22 m, tabel 1.2, Saayman ${ }^{13}$ ); en kruisingsbreedte, $D$ (21,5 tot $31,4 \mathrm{~m}$ gemeet te Stellenbosch) vanaf die stopstreep tot by die oorkant van die kruising. Om betyds te kan stilhou, vereis dat $d \geq s$, met die stilhou-afstand $s$ soos in (4) gedefinieer, en om betyds te kan oorry, vereis dat 


$$
\begin{aligned}
& v t_{r}+v\left(t_{l}-t_{r}\right)+\frac{1}{2} a\left(t_{l}-t_{r}\right)^{2} \geq d+D+L, \\
& \quad \text { of } d \leq v t_{l}+\frac{1}{2} a\left(t_{t}-t_{r}\right)^{2}-D-L=d_{o},
\end{aligned}
$$

sodat 'n dilemmasone bestaan waar

$$
s>d>d_{i} .
$$

Instelling van die bogespesifiseerde numeriese waardes in (4) en (6) lewer kwadratiese en lineêre spoedathanklike funksies vir $s$ en $d_{\text {, }}$ onderskeidelik, wat as paraboliese en reglynige grafieke in figuur 4 geskets is. Daaruit volg vir normale remming $\left(a_{b}=4 \mathrm{~m} / \mathrm{s}^{2}\right)^{15}$, it en duurte van die geellig $\left(t_{1}=3,5-4,0 \mathrm{~s}\right)$ dat die stilhou-afstand vir alle spoede groter as die oorsteekafstand, $s>d_{c}$, is. Daar bestaan dus 'n dilemmasone, bv. $d=48$ tot 51 of geringe 3 m lengte voor kruising 1 ; en $d=38$ tot 51 of aansienlike $13 \mathrm{~m}$ lengte voor kruising 2 vir die spoedgrens, $v=60$ $\mathrm{km} / \mathrm{h}$. Verhoging van die remvermoë tot $a_{b}=7,31 \mathrm{~m} / \mathrm{s}^{2}$ vir' 'n gemiddelde noodstop, skuif die paraboliese grafieke laer met $\mathrm{s}^{\prime}>d_{0}$ slegs by $v<28 \mathrm{~km} / \mathrm{h}$ vir kruising 1 , maar $v<51 \mathrm{~km} / \mathrm{h}$ en $v>106 \mathrm{~km} / \mathrm{h}$ vir kruising 2 ( kyk vertikale stippellyne). In plaas van remverhoging, kan die "ekstra grasietyd" ( 2 s te Stellenbosch) vandat dic verkeerslig na rooi verander totdat die verkeerslig in die dwarsrigting na groen verander (albei-rooitase), by die geelligtyd van 3,5-4.0 s getel word. In hierdie geval word albei $d_{1}$, reguitlyngrafieke na hoër stippellynposisies $d^{\prime}$, bokant die paraboliese $s$ kromme verskuif, sodat 'n dilemma slegs by spoede laer as - $15 \mathrm{~km} / \mathrm{h}$ kan voorkom.

Dit is belangrik dat bestuurders opgevoed word om die geel verkeerslig te respekteer as 'n waarskuwing om stil te hou (defensiewe optrede) eerder as 'n uitdaging om oor te jaag (offensiewe optrede).

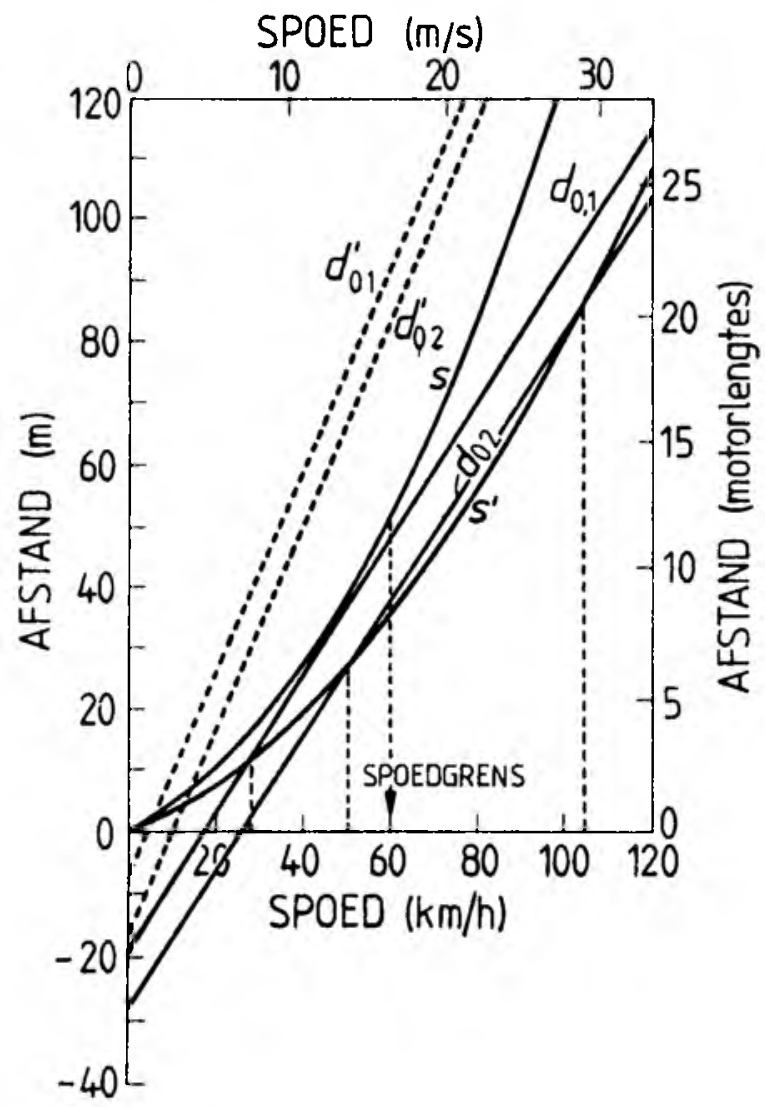

FIGUUR 4: Grafiese bepaling van dilemmasones by twee verkeersligbeheerde hoofstratkruisings in Stellenbosch $n l$. Birdstraat met Merrimanlaan (I) en Strandweg met Dorpstraat (2).

\subsection{Spoedbepalings uit wielsleepmerke}

In dic rekonstruksie van 'n voertuighotsing is dit belangrik om vas te stel of die snelheidsperk oorskry is en spoed 'n bydraende faktor was. In die geval van 'n noodlottige botsing, kan sodanige gevolgtrekking tot 'n klag van nalatige bestuur of selfs strafbare manslag lei. Spoedskattings kan gemaak word deur die toepassing van eenvoudige meganiese beginsels op gemete waardes van sowel wielsleepmerke as die glywrywing tussen die bande en padoppervlak. ${ }^{1719}$ Wanneer tydens 'n noodsituasie ten volle rem getrap word sodat die motorwicle ophou rol, vasklem en oor die pad skuurgly, neem die voertuigspoed van $v_{t}$, na $v$ af. Die bewegingsenergic word opgebruik as werk teen wrywing, $f$, oftewel omgesit tot termiese energie van die bande, wat die teeroppervlak smelt en smeer sodat remmerke van lengte $s$ nagelaat word. Die werk-energie-beginsel vereis dat

$$
\frac{1}{2} m\left(v^{2}-v_{0}^{2}\right)=F s=-(f \pm m g \sin \theta) s,
$$

waar die wrywingskrag empiries gedefineer word in terme van die normale stutkrag, $N$, van die pad wat die gewigskomponent, $m g \cos \theta$, balanseer sodat

$$
f=\mu N=\mu n g \cos \theta .
$$

Op 'n skuins, reguit pad word die wrywing versterk teen 'n opdraand ( + teken) of verswak teen 'n afdraand ( - teken) deur die gewigskomponent, $m g \sin \theta$. kyk figuur 5. As alternatief kan Newton se tweede bewegingswet vir konstante versnelling, $a$, ook gebruik word:

$$
F=-(f \pm m g \sin \theta)=m a=m\left(\frac{v^{2}-v_{0}^{2}}{2 s}\right) \text {. }
$$

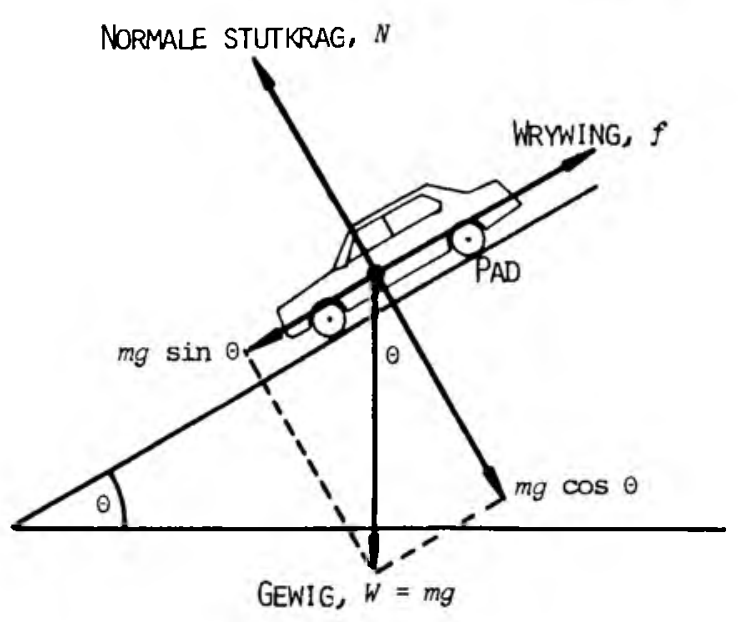

FIGUUR 5: Kragte uitgeoefen op 'n remmende voertuig deur 'n skuinspad.

Uit albei benaderings volg dat die spoed net voor remming bepaalbaar is uit

$$
v_{0}=\left[2 g s \cos \theta(\mu \pm \tan \theta)+v^{2}\right]^{1 / 2},
$$

wat onafhanklik van die voertuigmassa, $m$, is.

Die padhelling

$$
\tan \theta=\frac{y}{x}
$$

word bepaal deur 'n reguit staaf met lengte, $x$, op die betrokke pad te plaas en een punt tot vertikale hoogte, $y$, te lig totdat die staaf waterpas is. Die glywrywingskoëffisiënt tussen die slepende rubberbande en die padoppervlak word gedefinieer as die glywrywing per eenheidsvoer- 
tuiggewig. wat volgens (9) en (10) ook die verhouding van die vertraging tot die gravitasieversnelling op 'n gelyk pad $(0=0)$ is:

$$
\mu=\frac{f}{N}=\frac{f}{W}=\frac{a}{g}
$$

Dit word empiries bepaal deur 'n slee bestaande uit "n belaste motorband of houtraamwerk op stroke bandloopvlak (totale gewig $W$ ) teen konstante spoed (sodat die kragte balanseer) en met 'n trekskaal (lesing $T=f$ ) horisontaal oor die pad te sleep, kyk figuur 6. Op 'n skuins pad moet die waarde volgens (13) gekorrigeer word met die helling bepaal volgens (12). As alternatief kan toetsglye teen 'n gekontroleerde beginspoed van nie meer as $60 \mathrm{~km} / \mathrm{h}$ nie en verkieslik met die botsingsvoertuig uitgevoer word, die afstand, $s$, gemeet en $\mu$ met die inverse van (II) bereken word. Gemete waardes vir verskillende padmateriale, teksture en weersomstandighede word in die staafgrafick van figuur 7 aangedui en strek van so min as 0,05 op gladde ys tot sovecl as 1,2 op droë, growwe sement- of teerpaaic. Smcermiddels soos water, olie, modder, ens. verlaag die waardes met tot $25 \%$ op teer. In die praktyk is die wrywing effens kleiner by hoër $(>50 \mathrm{~km} / \mathrm{h})$ as by laer $(<50$ $\mathrm{km} / \mathrm{h}$ ) spoede, sodat die vertraging geleidelik toeneem tydens gly-tot-stop-beweging. ${ }^{20}$ Die wrywingskoëffisiënt is egter onalhanklik van die voertuiggewig, want alhoewel 'n swaar vragmotor meer krag vereis om tot stilstand te kom as 'n ligte passasiersmotor, is die wrywing van die pad op sy bande egter ook groter weens sy groter gewig.

Akkurate meting van die afstand $s$ is moeilik, omdat die sleepmerke eers geleidelik na die aanvang van remming sigbaar word, soms onderbroke is en nie altyd ewe lank en reguit verloop nie. Spoedbepaling volgens (11) verteenwoordig dus 'n konserwatiewe minimum tot voordeel van die bestuurder. Indien die botsingspunt uitgeken kan word uit 'n rigtingverandering van die spore. skrop- of wipmerke en/of voertuigafval soos olie-, water- en suurkolle, stukkies onderdele, glas, verf, roes, modder, ens., kan (11) twee keer gebruik word. Eerstens kan die spoed tydens botsing uit die sleepafstand na botsing bereken word. Met hierdie antwoord en die sleepafstand voor botsing, kan tweedens ook die spoed voor remming bereken word. In die spesiale geval van gly-tot-stop (eindspoed $\mathrm{y}^{\prime}=0$ ) op 'n horisontale pad $(\theta=0)$ vereenvoudig (11) tot die formule

$$
v_{0} \geq 15,9 \sqrt{\mu \mathrm{s}} \mathrm{km} / \mathrm{h} \text {. }
$$

waarvan waardes in oorsese botsingondersoekhandleidings $^{202}$ getabuleer en in figuur 8 grafies voorgestel word. Vir 'n tipiese geval van 'n aanvanklike spoed, $v_{10}=$ $60 \mathrm{~km} / \mathrm{h}$, op growwe, droë teer met $\mu=0,75$ behoort sleepmerke met lengte, $s=19 \mathrm{~m}$, nagelaat te word, mits dic voertuig natuurlik nie met 'n teenremklemtoestel toegerus is nie! Spoedbepalings is ook moontlik uit giermerke op paddraaie soos in afd. 3.5 bespreck word.

\subsection{Spoedbepalings uit projektielbeweging}

Beskou nou gevalle waar 'n voertuig self, of 'n voorwerp wat uit of na 'n bewegende voertuig geslinger word, as projektiel teen beginspoed, $v_{0}$, en elevasic, $\theta$, met die horisontaal deur dic lug tot vertikale hoogte, $y$, trek en die grond weer 'n horisontale afstand, $x$, daarvandaan tref, soos in figuur 9. Indien lugwrywing weglaatbaar klein is ('n gocic benadering vir lae spoede en kort valafstande), geskied hicrdie projektielbeweging teen 'n konstante spoed, $v_{1}$, in die horisontale rigting en teen konstante gravitasieversnelling, $g$, in die vertikale rigting. Die posisickoördinate as funksies van tydsverloop, $t$, word dan respektiewelik beskryf deur

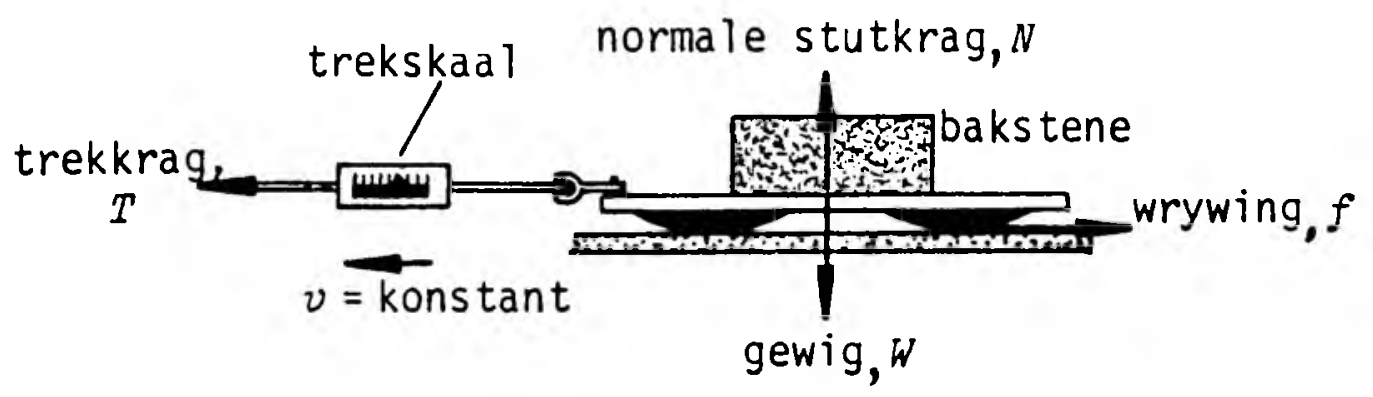

FIGUUR 6: Treksleemetode vir die bepaling van die wrỵingskö̈ffisiënt, $\mu$, tussen die voertuigbande en padoppervlak.

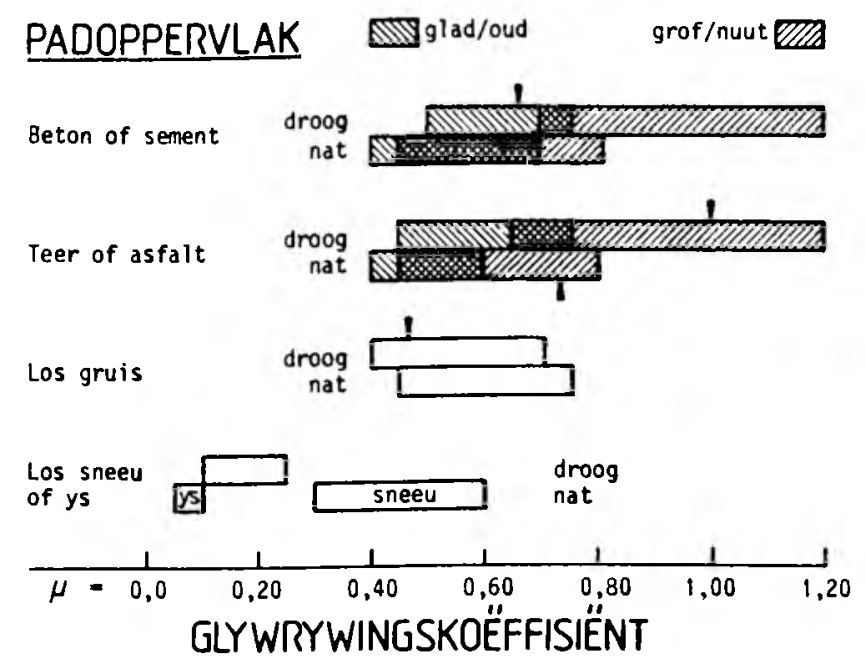

FIGUUR 7: Omvang van glywrywingskö̈ffisiënte, $\mu$, vir verskillende drö̈ en nat padoppervlakke (saamgestel wit waardes in Exhibit 9-5 van die Traffic Institute, Northwestern University, Evanston, Illinois ${ }^{2 \prime}$, met pyltjies wat eie plaaslike metings aandui). 


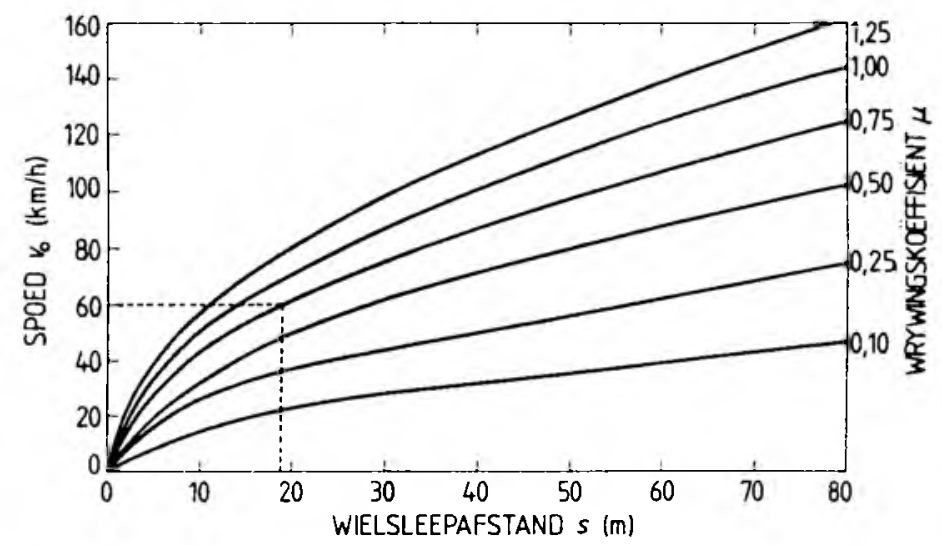

FIGUUR 8: Grafieke van die beginspoed, $v_{0}$, as funksie van die lengte van wielsleepmerke, $s$, en die wrywingskoëffisiënt, $\mu$, op 'n gelyk pad.

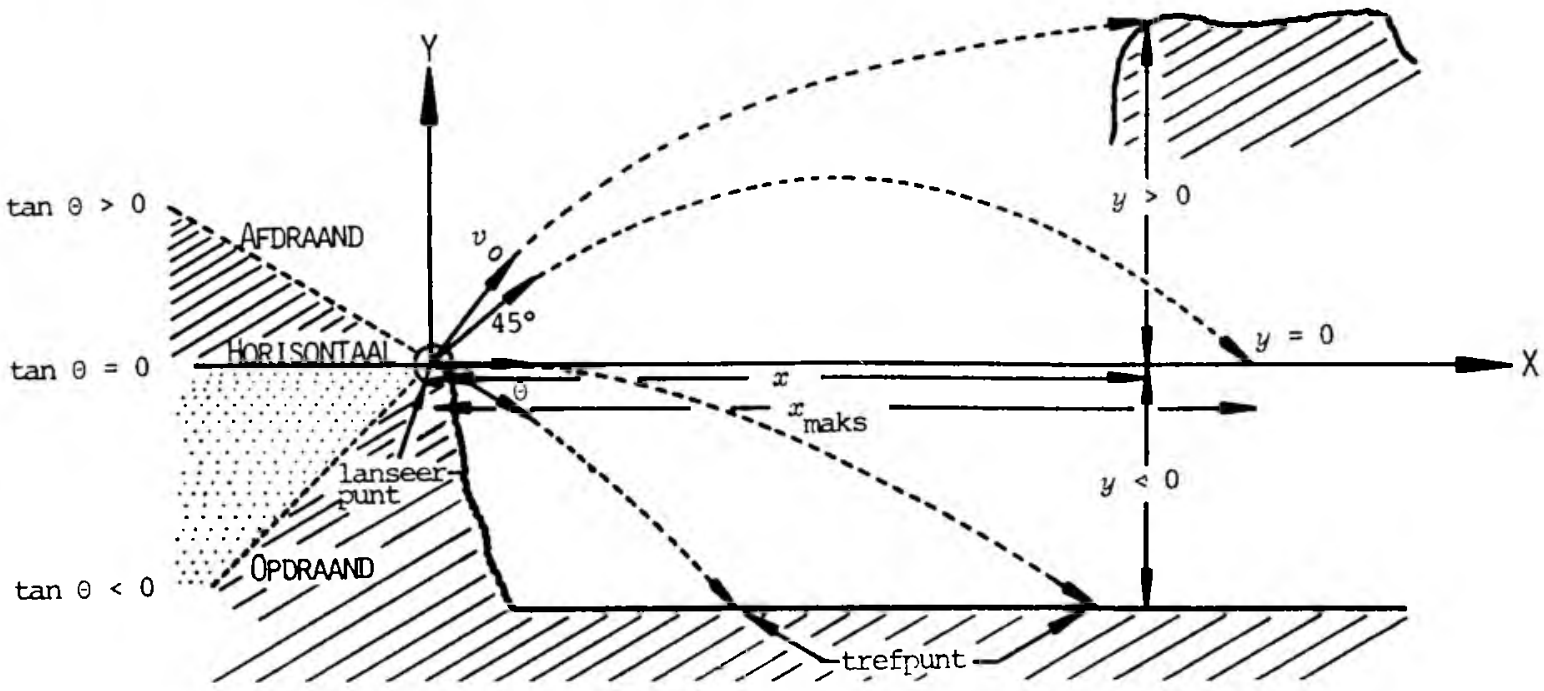

FIGUUR 9: Veranderlikes benodig vir die fisiese beskrywing van projektielbeweging.

Eliminasie van die tyd lewer die paraboliese baanvergelyking van die massamiddelpunt van die projektiel as

$$
y=(\tan \theta) x-\left(\frac{g}{2 v_{0}^{2} \cos ^{2} \theta}\right) x^{2},
$$

wat herrangskik kan word sodat die lanseerspoed,

$$
\begin{aligned}
v_{\mathrm{o}} & =\frac{x}{\cos \theta} \sqrt{\frac{g}{2(x \tan \theta-y)}} \\
\text { of } v_{\mathrm{s}} & \geq \frac{7,97 x}{\sqrt{x \tan \theta-y}} \mathrm{~km} / \mathrm{h}(\theta \text { klein }),
\end{aligned}
$$

na benadering van $\cos \theta \simeq 1$ vir klein $\theta$. Waardes hiervan vir horisontale lansering $(\theta=0=\tan \theta)$ word grafies as reguitlyne in figuur 10 voorgestel. So byvoorbeeld is 'n spoed van ongeveer $60 \mathrm{~km} / \mathrm{h}$ bepaalbaar uit gemete valafstande van $(x ; y)=(7,5 ; 1)$ of $(17 ; 5)$ of $(24 ; 10)$ of $(34 ; 20)$ $m$, ens. vir ' $n$ voertuig wat self deur die lug trek, of afvalstukke soos vrag, voorruitglas of onderdele wat tydens 'n botsing wat die voertuig tot stilstand bring, op die pad beland.

Wanneer 'n vinnigbewegende voertuig teen 'n starre hindernis soos die randsteen op 'n hoogte laer as sy massamiddelpunt bots, sal die slagimpuls 'n draaimoment om die kontakpunt uitoefen. Dit kan die voertuig stert-oor-kop of sydelings laat omkantel en omtol tydens sy projektielvlug, om dan dikwels op sy dak of sykant te lande te laat kom. Omdat die lanseerhoek, $\theta$, in so 'n geval moeilik bepaalbaar is, word dit op $45^{\circ}$ vir maksimum horisontale trefwydte en minimum lanseerspoed gestel, ${ }^{18}$ wat 'n goeie benadering vir 'n klein $\frac{x}{y}$ verhouding is, sodat (17) vereenvoudig tot

$$
v_{o}=\frac{11,3 x}{\sqrt{x-y}} \mathrm{~km} / \mathrm{h} \quad\left(\theta=45^{\circ}\right)
$$

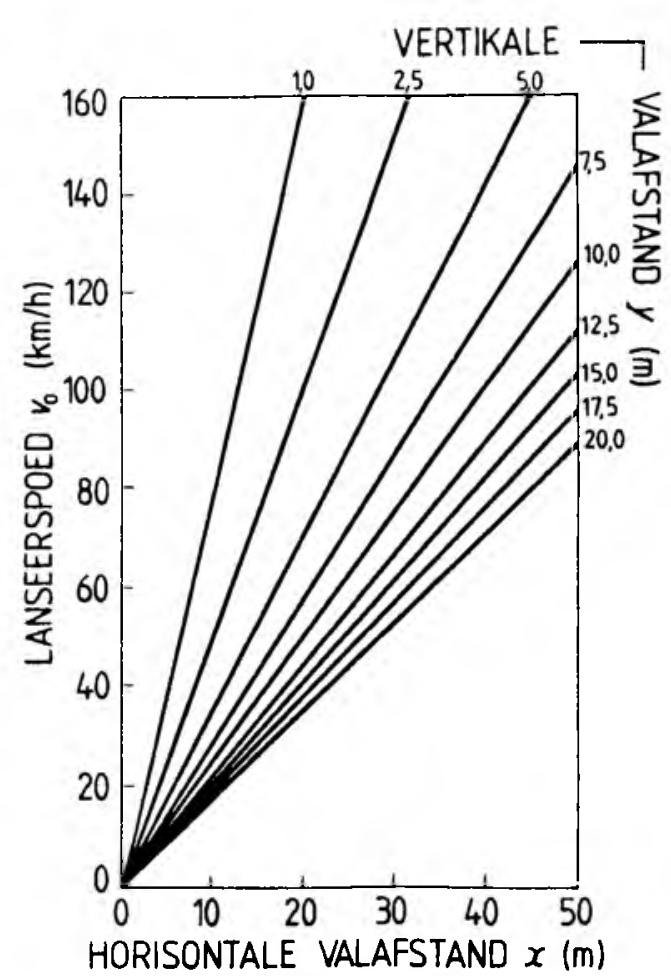

FIGUUR 10: Grafieke van die horisontale lanseerspoed, $v_{\text {,, }}$ as funksie van die horisontale en vertikale valafstande $(x, y)$ tydens projektielspronge deur die lug na horisontale lansering. 


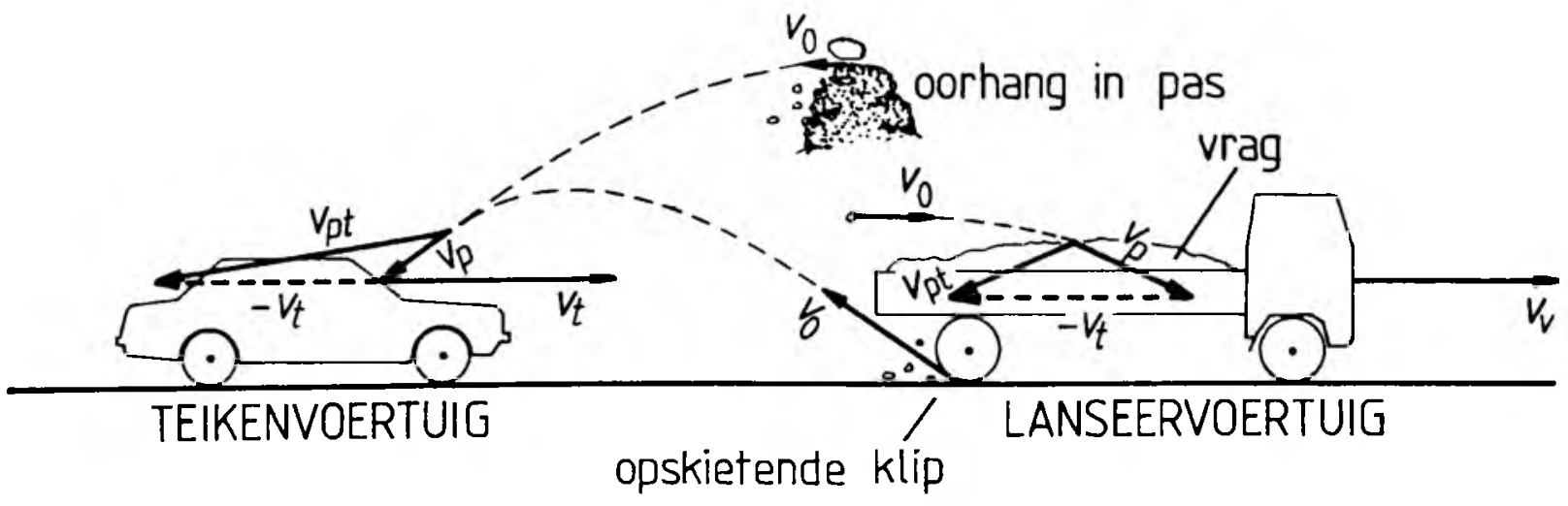

FIGUUR 11: Relevante snelheidvektore vir projektiele soos klippe wat bewegende voertuie op paaie tref.

'n Gevaarlike projektielverskynsel wat ook dikwels op paaie voorkom, is dié van vragstukke wat van bewegende vragvoertuie afval; klippe wat deur voertuigwiele opgeskiet of deur onrusmakers langs die pad gegooi word; en rotsstukke wat bokant die pad in bergpasse losbreek om deur die lug te trek en verbygaande verkeer te tref. Alhoewel die valafstande in sulke gevalle nie direk meetbaar is nie, geld bostaande fisiese vergelykings ook in beginsel. Formule (17) kan gebruik word om die lanseerspoed van die projektiel, $v_{0}$, te skat en daarmee dan die komponente van die eindsnelheid by die trefpunt in rus, $\vec{v}_{p}$, uit die projektieluitdrukkings

$$
v_{x}=v_{0} \cos \theta \text { en } v_{y}=v_{0} \sin \theta-g t
$$

te bereken. Die vektorverskil hiervan en die snelheid van die teikenvoertuig, $\vec{v}_{t}$, gee dan volgens afd. 2.1 die snelheid van die projektiel relatief tot die bewegende teiken

$$
\vec{v}_{p t}=\vec{v}_{p}-\vec{v}_{t}
$$

soos in figuur 11 geskets.

\section{VOERTUIGSTABILITEIT}

\subsection{Traagheid of inersie}

Alle liggame verset hulle inherent weens hulle materiële samestelling teen verandering in hul bewegingstoestand. Indien geen resulterende, eksterne krag op 'n liggaam uitgeoefen word nie, bly dit volgens Newton se eerste bewegingswet in 'n ewewigtoestand van rus of eenvormige beweging (reglynig teen konstante spoed). Hierdie traag- heidsbeginsel manifesteer as "luiheid" van 'n stilstaande voertuig en passasiers daarbinne om te begin beweeg; of indien dit alreeds beweeg, vinniger of stadiger te beweeg en van rigting te verander. Traagheid word kwantitatief in terme van die massa, $m$, uitgedruk. Die insittendes van 'n voertuig wat teen $a$ versnel, ondervind traagheidskragte, $F=m a$, wat met stippellyne in figuur 12 aangetoon word. Anders as gewone kragte soos gravitasie en wrywing, ontstaan traagheidskragte nie uit werklike fisiese wisselwerking tussen materiële liggame nie, maar weens die versnelling van die assestelsel (voertuig) ten opsigte waarvan hul beweging beskryf word, en is ook altyd teenoorgesteld tot die beweging gerig. ${ }^{23}$ Volgens Einstein se ekwivalensiebeginsel kan traagheidskragte ook nie van gravitasiekragte onderskei word nie en verskaf dit dus, tesame met die gewig, 'n kunsmatige swaartekragveld vir waarnemers wat saam met die assestelsel versnel word.

\subsection{Massasentrum of swaartepunt}

Vir die studie van stabiliteit om draaie en tydens botsings wanneer sydelingse kragte op 'n voertuig inwerk, is dit nodig en gerieflik om sy totale gewig, $W=m g$, by 'n enkele punt, $\mathrm{S}$ te laat aangryp. Die posisie daarvan is 'n geweegde gemiddelde van al die posisies van die $N$ puntdeeltjies waaruit die ruimtelik uitgebreide liggaam opgebou is:

$$
\vec{R}=\sum_{i=1}^{N} m_{i} \vec{r}_{i} / \sum_{i=1}^{N} m_{i} .
$$

Dit is rofweg op sy middellyn effens nader aan die vooras as agteras (in geval van voorenjinplasing) en effens laer as die middel van sy hoogte bokant die pad geleë, maar ver-

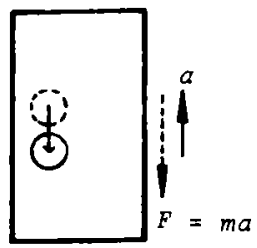

(a) Skielike wegtrek

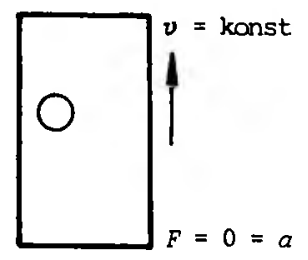

(b)

Eenvormige beweging

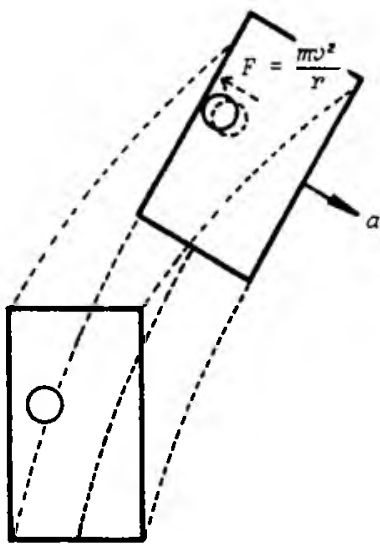

(c) Skielike rigtingverandering

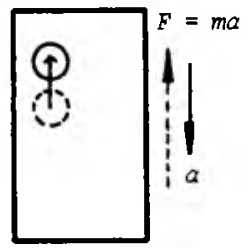

(d) Skielike reming

FIGUUR 12: Traagheidseffekte op 'n passasier in 'n bewegende voertuig. 


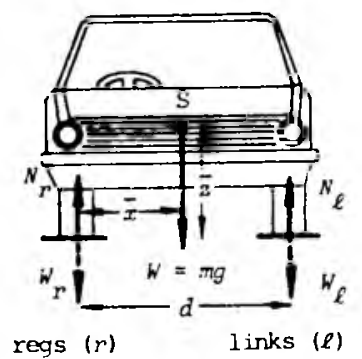

(a) Vooraassig

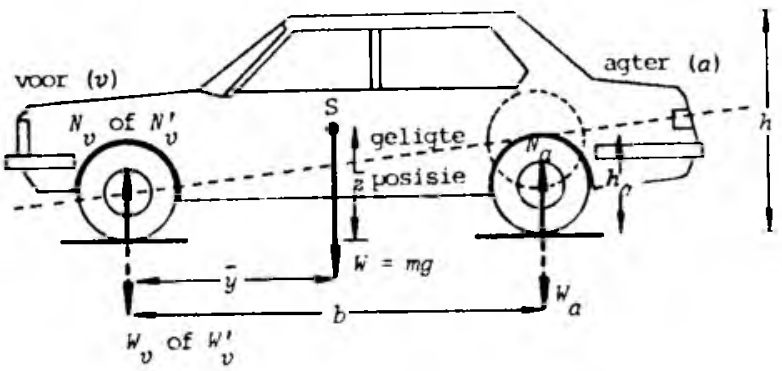

(b) Sy-aansig

FIGUUR 13: Posisie van die massasentrum. S, en kragte op die linker(l)-, regter(r)-, voor(v)-en agter(a)-wiele van 'in veertuig in rus op in gelyk pad of weegbrug.

skuif natuurlik volgens die verdeling van passasiers en v rag. Akkurate driedimensionele swaartepuntbepaling is noontlik volgens

$\bar{x}=\frac{W_{1}}{W} d_{v}-\frac{d}{2}: \bar{y}=\frac{W_{u}}{W} b \sim \frac{b}{2} ; z=\frac{W_{1}^{\prime} b-W(b-\bar{y})}{W \tan \left(\sin ^{-1} \frac{h_{a}}{b}\right)}-\frac{h}{2}$.

verkry deur toepassing ${ }^{21}$ van die wet van draaimomente respekticwelik om die regterwicle, vooras en geligde agteras van die stilstaande voertuig. Dit vereis meting van die gewig op die linkerwiele. $W_{l}$, agterwiele, $W_{u}$, en voorwiele, $W_{r}^{\prime}$ (met die agteras 'n hoogte, $h_{u}$. opgelig) op 'n weegbrug, asook die spoorwydte, $d$, wielbasis (asafstand), $b$, en hoogtes, $h_{a}$ of $h$, soos getoon in figuur 13. Dit lewer numeries byvoorbeeld $(0,72 ; 1,31 ; 0,70)$ meter vir 'n tipiese gesinsmotor ( $\mathrm{H}$-model, tabel 1, Saayman ${ }^{13}$ ).

\subsection{Dinamiese ewewigvoorwaardes}

'n Voertuig met traagheidsmassa, $m$, en spoed, $v$, vereis volgens Newton se tweede bewegingswet 'n sentripetale krag en versnelling van grootte

$$
F_{s}=m a_{1}=\frac{m v^{2}}{r}
$$

om dit van sy normale, reglynige beweging volgens Newton se eerste bewegingswet te laat afwyk en om 'n draai in die pad met krommingstaal, $r$, te laat beweeg. Die voertuig en insittendes ervaar dit as 'n sentrifugale traagheidskrag van dieselfde grootte, maar teenoorgestelde rigting. wat neig om hulle weg in plaas van na die krommingsmiddelpunt (d.w.s na die buitekant van die draai) te "gooi". Dit word met stippelpyle op figuur 14 en verderaan getoon,

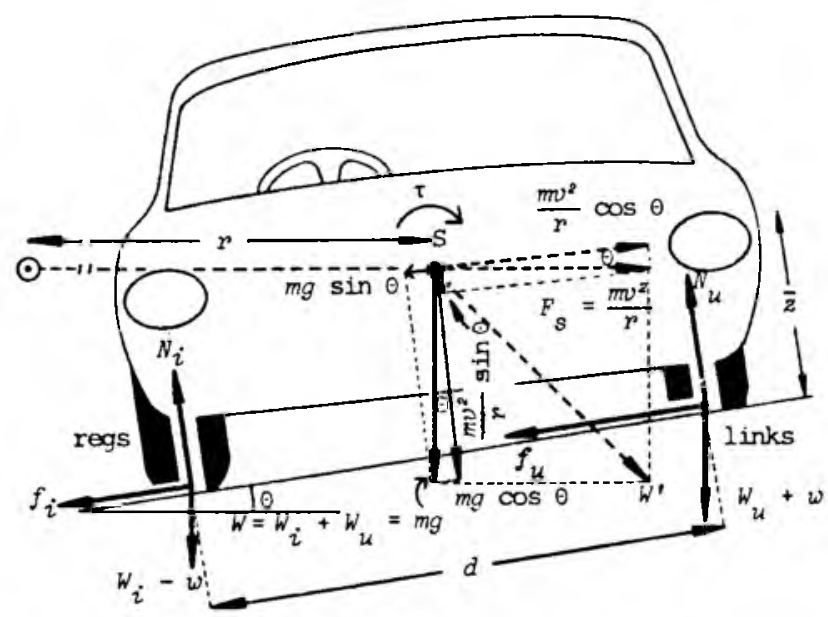

FIGUUR 14: Kragte en gewigsierplasing op 'n bewegende voertuig om 'n draai op 'n skuinsgebankte pad. waar die pad om veiligheidsredes (kyk na afd. 3.5) ook teen in hoek, $\theta$, dwarsgebank is.

Die volgende drie balansvergelykings, waarin onderskei word tussen kragte op die binnckantste $(i)$ en buitekantste (u) wiele. moet in hierdie geval bevredig word:

(a) Kragte ewewydig aan die pad:

$$
f_{i}+f_{u}+m g \sin \theta=\frac{m v^{2}}{r} \cos \theta \text { : }
$$

(b) Kragte loodreg op die pad:

$$
N_{i}+N_{u}-m g \cos \theta=\frac{m v^{2}}{r} \sin \theta \text {; }
$$

(c) Draaimomente, $\tau=F d$, as produkte van die krag, $F$, met die loodregte afstand, $d$, vanaf die werklyn om enige gekose draaipunt soos die swaartepunt, $S$ :

$$
\left(f_{i}+f_{u}\right) \bar{z}=\left(N_{u}-N_{i}\right) \bar{x},
$$

of die binnekantste (i) of buitekantste $(u)$ wiele:

$\left(\frac{m v^{2}}{r} \cos \theta-m g \sin \theta\right) \bar{z}=\left(\frac{m v^{2}}{r} \sin \theta+m g \cos \theta\right) \bar{x}$

\subsection{Gewigsverplasing}

(a) Om draaie: Vektorieel saangestel (figuur 14) met die werklike gewig, $W$, veroorsaak die sentrifugaalkrag. $F$, in skynbare gewigsverplasing

$$
W^{\prime}=\sqrt{W^{2}+F_{s}^{2}}=\sqrt{1+\left(\frac{v^{2}}{g r}\right)^{2}} W>W
$$

na die buitekant van die draai, wat die voertuig- en passasiersbalans versteur, die klouvermoë van die bande verminder en die voertuig sydelings kan laat uitgly (kyk na afd 3.5). Die manier waarop passasiers die sentrifugalalkrag op hulle (slegs $5-10 \%$ van dié op voertuig) ervaar, hang van hul sittende ruggraatoriëntasie af. Vir rygemak en minimum bewuswording van die draai, behoort dit altyd parallel aan die kragresultant, $\vec{W}^{\prime}$, te wees. Op 'n paddraai met gelyk oppervlak van goeie gehalte (geen los gruis of knikke nie), is sodanige oriëntasie moontlik vir 'n skynbare gewigsvermeerdering van minder as $2 \% .{ }^{17.22}$ Dit impliseer 'n sentrifugaalversnelling, $a_{s} \leq 0,2 \mathrm{~g}$, en waarde kleiner as $11^{\circ}$ vir die oorhelhoek

$$
\alpha=\tan ^{\prime} \frac{F_{s}}{W}=\tan ^{-1} \frac{\nu^{2}}{g r} .
$$

Dié voorwaarde kan ook bevredig word deur 'n draai korrek skuins te bank, $\theta=\alpha$. So nie leun die passasiers instinktief na die binnekant van die draai oor (soos duidelik sigbaar is by motorfietsryers), sodat die hersteldraaimoment van hul eie gewig die andersom draai- 


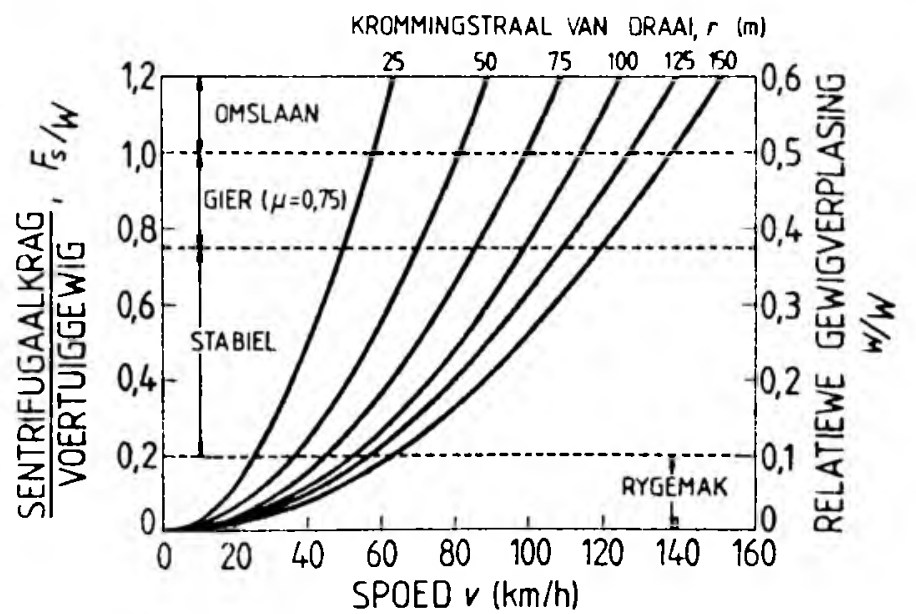

monient van die sentrifugaalkrag op hulle uitkanselleer.

Die sentrifugaalkrag, $F_{s}$, verander ook die aanvanklike egalige voertuiggewigsverspreiding op al vier wiele $\left(W_{i}=W_{u} \simeq \frac{W}{2}\right)$ en verskuif 'n hoeveelheid, $w$, van die totale voertuiggewig, $W$, vanaf die binnekantse wicle $\left(W_{1}-w^{\prime}\right)$ na die buitekantste wiele $\left(W_{u}+w^{\prime}\right)$. Uit samevoeging van die balansvergelykings (25), (26) en (27) volg dan dat

$$
\left(\frac{m v^{2}}{r} \cos \theta-m g \sin \theta\right) \bar{z}=2 n \bar{x} \cos \theta,
$$

sodat die relatiewe gewigsverplasing

$$
\frac{w}{W}=\left(\frac{\nu^{2}}{g r}-\tan \theta\right) \frac{\bar{z}}{2 \bar{x}} \simeq(\mu-\tan \theta) \frac{h}{2 d},
$$

waar (13) vir die wrywingskoëffisiënt gebruik is. Grafieke van die relatiewe sentrifugaalkrag, $\frac{F_{3}}{W}=$ $\frac{v^{2}}{g r}$, en gewigsverplasing, $\frac{w^{\prime}}{W}=\frac{v^{2} h}{2 g r d}$, met tipiese $\frac{h}{d}=1$ verhouding vir gesinsmotors, word as funksie van sowel die spoed, $v$, om die draai as die straal, $r$, van 'n ongebankte $(\theta=0)$ paddraai in figuur 15 aangebied. Die snypunte van die krommes met die boonste horisontale $F_{s} / W=1$ stippellyn toon die kritieke $(v, r)$ kombinasies (bv. $80 \mathrm{~km} / \mathrm{h}$ en $50 \mathrm{~m}$ ) waar die sentrifugaalkrag en gewig ewe groot is. Dit impliseer 'n $50 \%$ gewigsverskuiwing vanaf dic binnekantste na die buitekantste wiele, sodiat die voertuig wil omkantel (kyk ook na afd. 3.6). Teen 'n laer spoed, groter radius of op 'n gebankte $(\theta \neq 0)$ draai sal $F_{s}$ en $w$ afneem.

(b) Tydens skielike remming of versnelling: Wanneer 'n voertuig skielik op 'n reguit, skuins pad gerem word, oefen padwrywing op die voor- en agterwiele, $f=f_{v}$ $+f_{a}$, 'n terugwaartse vertragingskrag, $F_{a}=m a$, en
FIGUUR 15: Grafieke l'an die sentrifugallkrag per voertaiggewig, $F, W$, en relatiewe gewigsverplasing vir 'n tipiese gesinsmotor $h / d$ - l as fimksie van die spoed, v, om 'ndraai en straal, $r$, van 'n drati op 'n ongebankte pad.

linksom draaimoment om die swaartepunt uit. Dit verplaas 'n hoeveelheid, $w$, van dic totale gewig vanaf die agterwicle $\left(W_{c}\right)$ na die voorwiele $\left(W_{v}\right)$, soos waarneembaar is (figuur 16a) uit die neus van die voertuig wat sak en die stert wat lig. Die pad reageer met 'n regsom hersteldraaimoment sodat momentebalans soortgelyk soos in (32) hier bo, die relaticwe gewigsverplasing

$$
\frac{w}{W}=\left(\frac{a}{g} \pm \tan \theta\right) \frac{\bar{z}}{2 \bar{y}} \simeq(\mu \pm \tan \theta) \frac{h}{2 b}
$$

lewer, waar die + teken vir 'n opdraand en die - teken vir'n afdraand geld soos in afd 2.4. Dieselfde uitdrukking, maar omgekecrde gewigsverplasing, geld vir 'n voertuig wat skielik wegtrek of versnel (figuur $16 \mathrm{~b}$ ). Vir 'n gemiddelde $75 \%$-doeltreffendheid wanneer al vier wiele op 'n gelyk pad $(\theta=0)$ rem, sodat die vertragingskrag driekwart van die voertuiggewig beloop (kyk afd 2.2), lewer (33) 'n 20\%-gewigsverplasing van agter na voor vir 'n tipiese gesinsmotor $(\overline{\bar{z}} \overline{\overline{2}}=0.26)$

Die gewigsverplasing van voor na agter tydens skielike versnelling is ongeveer die helfte hiervan, omdat slegs die agter- óf voorwiele normaalweg aangedryf word.

\subsection{Sydelingse gierbeweging}

Uit (25) en (26) blyk dat op 'n gelyk $(\theta=0)$ paddraai slegs wrywing, $f$, tussen die pad en bande die sentripetaalkrag, $F_{s}$, verskaf, wat die voertuig op die draai hou. In geval van 'n te hoë spoed, om skerp draaie of swak padtoestande (los gruis, gladde of nat teer) kan die wrywing onvoldoende wees, sodat die voertuig na buite uitgly of gier. Ten einde die rol van wrywing te beperk, word draaie op snelweë

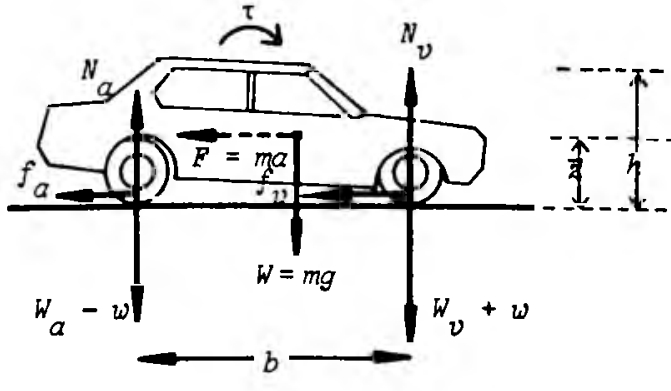

(a) Skielike reming

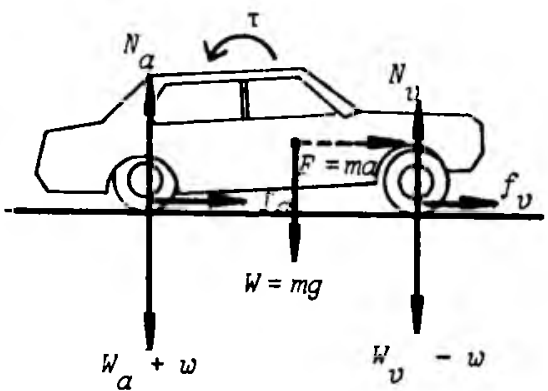

(b) Skielike versnelling

FIGUUR 16: Kragte en gewigsverplasing op 'n voertuig tydens skielike remming of versnelling op 'n gelyk, reguit pad. 
skuins teen 'n dwarshellingshoek, $\theta$, gebank, sodat die voertuiggewigskomponente, $m g \sin \theta$ en $m g \cos \theta$, en die stutkrag, $N$, van die pad grotendeels tot $F_{s}$ bydra. Deur gebruik van die empiriese verband, $f=\mu N$, uit (13), lewer gelyktydige oplossing van (25) en (26) die kritieke spoed waarbo, of kritieke hoek waaronder die voertuig uit dic draai sal begin gly weens onvoldoende sentripetaalkrag of

$v_{k g}=\sqrt{g r\left(\frac{\mu+\tan \theta}{1-\mu \tan \theta}\right)} ; \theta_{k g}=\tan ^{-1}\left(\frac{\frac{v_{k g}^{2}}{g^{r}} \mu}{1+\frac{\mu v_{k g}^{2}}{g r}}\right)$

Die eerste uitdrukking kan gebruik word om die kritieke spoed vir 'n bepaalde paddraai, asook die minimum spoed van 'n voertuig wat uit die draai gegly en giermerke nagelaat het, te bereken en is soos die spoedbepalings van afds. 2.4 en 2.5 onafhanklik van die voertuigmassa. Die dwarshellingshoek, $\theta$, en wrywingskoëffisiënt, $\mu$, word gemeet soos beskryf in afd 2.4. Die krommingstraal, $r$, word bereken volgens die geometriese formule

$$
r=\frac{k^{2}}{8 h}+\frac{h}{2} \text {. }
$$

Dit vereis eerstens meting van die koordlengte, $k$, tussen punte $A$ en $C$, op die verdelingslyn van die pad aan weerskante van die draai waar die pad begin reguit loop (figuur 17). As alternatiewe waarde vir $k$ kan 'n derde van die gemete giermerklengte van slegs die buitenste wiele, of die gemiddelde van ál die glyende wiele geneem word. Tweedens moet die niddelordinaat, $h, \mathrm{n}$. die maksimale loodregte hoogte vanaf die koordmiddelpunt $D$ na die buitekant $B$ van die draai ook bepaal word. In die spesiale geval van 'n ongebankte draai $(\theta=0)$ vereenvoudig (34) tot

$$
v_{k g}=\sqrt{\mu g r}=11,3 \sqrt{\mu r} \mathrm{~km} / \mathrm{h} \quad(\theta=0),
$$

en met die algehele uitskakeling van wrywing $(\mu=0)$ tot

$$
\begin{gathered}
v_{k g}=\sqrt{g r \tan \theta}=11,3 \sqrt{r \tan \theta} \mathrm{km} / \mathrm{h} ; \\
\theta_{k g}=\tan 1 \frac{v_{k g}^{2}}{g r}(\mu=0),
\end{gathered}
$$

waarvan uitgewerkte waardes getabuleer ${ }^{20-22}$ en in figuur 18 grafies voorgestel word. So byvoorbeeld sal 'n voertuig op 'n draai met $r=50 \mathrm{~m}$ en $\mu=0,75$ teen 'n spoed bokant $69 \mathrm{~km} / \mathrm{h}$ begin uitgly indien die pad ongebank is, maar eers bokant $82 \mathrm{~km} / \mathrm{h}$ indien $\theta=10^{\circ}$ in (34), terwyl 'n dwarshelling van $36,9^{\circ}$ vereis word om wrywing heeltemal uit te skakel by eersgenoemde kritieke spoed.

\subsection{Omslaan om 'n draai}

Teen 'n hoog genoeg spoed op 'n bepaalde paddraai verskuif ál die gewig van die voertuig na sy buitekantste wiele $\left(\frac{w}{W}=50 \%\right.$ in (32) en $N_{i}=W_{i}=f_{i}=0$ in figuur 14).

Dit sal dan sywaarts begin kantel en selfs omslaan indien die regsom draaimoment groter as die linksom draaimoment word en die swaartepunt $S$ verby die steunpunt van die buitekantste wiele op die pad skuif. Die kritieke spoed waarbo 'n voertuig op 'n draai sal omslaan, volg uit die kombinasie van balansvergelykings (25), (26) en (27) of direk uit momentebalans (28) as

$v_{h u}=\sqrt{\frac{g r(x+\bar{z} \tan \theta)}{\bar{z}-\bar{x} \tan \theta}} \simeq \sqrt{\frac{g r(d+h \tan \theta)}{h-d \tan \theta}}$

Waardes daarvan kan uit die snypunte van die boonste stippellyn met die krommes op figuur 15 vir 'n tipiese gesins-

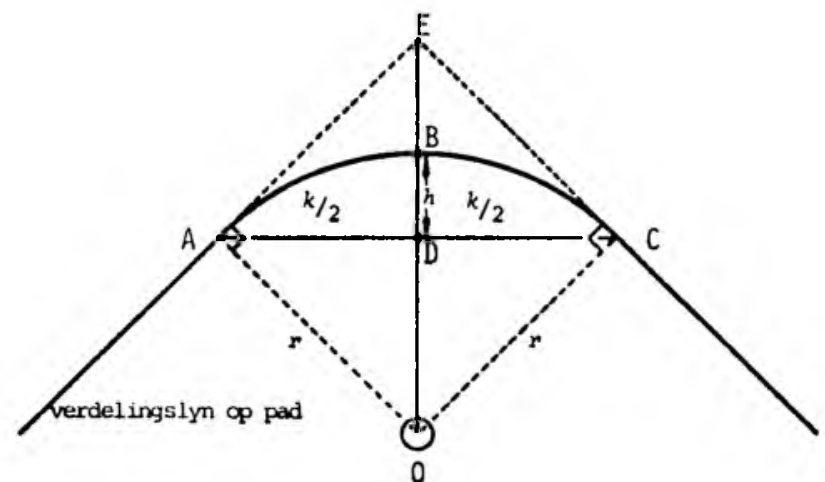

FIGUUR 17: Geometriese bepaling van die krommingstraal van 'n draai in die pad.

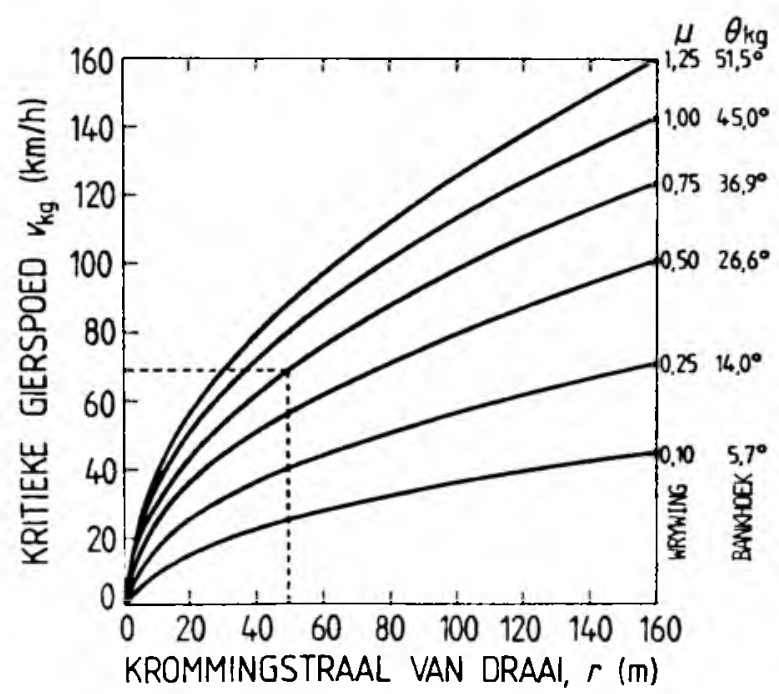

FIGUUR 18: Grafieke van kritieke gierspoed, vig, op 'n draai in die pad as funksie van die krommingstraal, $r$, en wrywingskö̈ffisiënt, $\mu$, of ekwivalente dwarshellingshoek, $0_{k g}\left(=\tan ^{-1} \mu\right)$.

motor $\left(\frac{d}{h} \sim 1\right)$ op 'n ongebankte $(\theta=0)$ paddraai afgelees word, bv. $80 \mathrm{~km} / \mathrm{h}$ vir $r=50 \mathrm{~m}$. Vergelyking met die kritieke glyspoed, $v_{k g}$, volgens (34) toon dat indien die geometriese verhouding, $\frac{d}{h}>\mu$, die wrywingskoëffisiënt, die voertuig slegs sal uitgly, maar nie omslaan nie. Voertuigontwerp vir verhoogde stabiliteit veral on draaie impliseer dus 'n groter spoorwydte, $d$, en/of laer swaartepunt $\bar{z}$, soos by renmotors duidelik die geval is.

\subsection{Vragverskuiwing}

Tydens skielike versnelling, remming, om-n-draai-beweging of botsing van 'n voertuig, ondervind passasiers en vrag traagheidskragte wat hulle dinamiese ewewig relatief tot die bewegende voertuig versteur, sodat hulle uit posisie skuif of gly, heen en weer slinger, omkantel en selfs uitof afval, tensy hulle vasgegord of -gebind is. Gestel soos in figuur 19 'n voertuig met vrag van massa, $m$, en eenvormige horisontale en vertikale afmetings, $d$ en $h$, het ' $n$ versnelling, $a$, na links met betrekking tot die gelyk, reguit pad. As gevolg van sy traagheid ondervind die vrag 'n inersiaalkrag, $F=m a$, in die teenoorgestelde rigting na regs relatief tot die vragmotor. Indien $a$ nie te groot is nie, is $F$ in stabiele ewewig met die fisiese kragte, nl. die vraggewig, $W=m g$, en die reaksiekrag van die voertuigvloer, 


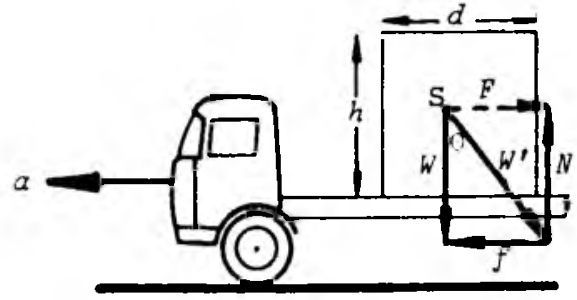

(a) Stabiele vrag

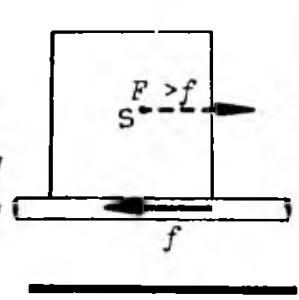

(b) Vrag gly agteruit

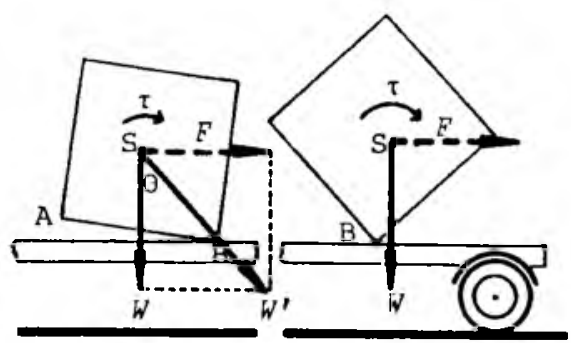

(c) Vrag begin roteer (d) Vrag kantel om

FIGUUR 19: Vragverskuiwing op 'n versnellende voertuig.

wat uit twee komponente - die wrywing $f$ en normale stutkrag $N$ - bestaan. Hulle vorm 'n geslote kragreghock en hul werklyne sny deur die swaartepunt $S$ (kyk figuur 19(a)). Soos die versnelling toeneem, vergroot die traagheidskrag en raak die wrywing onvoldoende om dit op te hef. Dan geld die voorwaarde vir translasie $(\mathrm{t})$

$$
F_{t} \geq f \text { en } a_{t} \geq \mu_{1} g,
$$

sodat die vrag agteruit begin gly en moontlik kan afval (figuur 19(b)). Die netto versnelling van die vrag ten opsigte van die pad ( $p$ ) word verkry deur vektoriële samestelling van $a$, by $a$ van die voertuig self:

$$
a_{t p} \geq\left(\mu_{p}-\mu_{1}\right) g \text {, }
$$

waar onderskei word tussen die wrywingskoëffisiënte van die bande op die pad, $\mu_{p}$, en van die vrag op die voertuigvloer, $\mu_{1}$. Soos a toeneem, verskuif die skynbare swaartelyn van $\vec{W}=\vec{W}+\vec{F}$ al hoe meer na agter vanaf A na B op die kontakbasis. Wanneer dit in figuur 19(c) deur die agterpunt B sny, begin die voorpunt $A$ lig en die vrag om $B$ te roteer. Die linksom hersteldraaimoment van die gewig, $W \frac{d}{2}$, verminder weens die momentarm wat kleiner as $\frac{d}{2}$ word tydens rotasie wanneer die werklike swaartelyn al nader aan B beweeg, en raak onvoldoende om die regsom draaimoment, $F \frac{h}{2}$, te balanseer. Hierdie onstabiliteitvoorwaarde vir rotasie (r) vereis dat

$$
F_{r} \frac{h}{2}>W \frac{d}{2} \text { of } F_{r}>\frac{m g d}{h} \text { en } \mathbf{a}_{r}>\frac{g d}{h} \text {. }
$$

Die vrag hou dus aan roteer en kantel om met verlaging in swaartepunt sodra $S$ vertikaal verby die steunpunt $B$ beweeg (figuur 19(d)).

Voorwaardes (39) en (41) geld ook vir skielike remming of botsing (keer slegs die rigtings van $F$ en $f$ op figuur 19 om) en lewer weer kritieke spoede (36) en (38) vir beweging om 'n draai wanneer die sentrifugaalkrag, $F_{r}=\frac{m v^{2}}{r}$, as traagheidskrag optree.
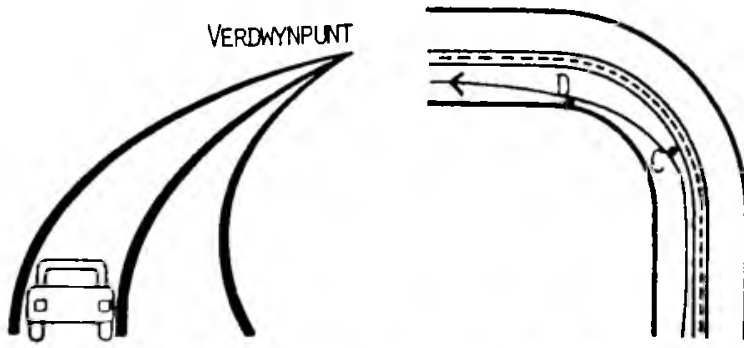

(a) Naderende draai

(b) Draai na links

\subsection{Veilige beweging om 'n draai}

Die bestuurder is hoofsaaklik te blameer wanneer 'n voertuig op 'n draai buite beheer raak weens versuim om doeltreffend spoed te verminder, oorstuuraksie, te kwaai remming en versnelling wat die sentrifugaalkrag (24) vergroot en die balans versteur. 'n Voertuig met voorenjinplasing $\left(W_{v}>W_{a}\right)$ en/of te lac voorbanddruk neig om te onderstuur, nl. te wyd om 'n draai te beweeg, terwyl agterenjinplasing $\left(W_{a}>W_{v}\right)$, te lae agterbanddruk en/of radiale voorbande gekombineer met kruislaagagterbande dit weer laat oorstuur, nl. 'n draai te skerp sny. ${ }^{24}$ Renjacrs maksimiseer hulle spoed per beskikbare drylkrag om 'n draai deur so wyd moontlik daarom te ry en 'n konstante groot radius, $r$, te handhaaf (figuur 20). Om veiligheidsredes word aanbevee $\left.\right|^{2+26}$ dat gewone motoriste daarenteen die draaibeweging teen 'n skerper hoek uitvoer, ten einde hulle uitsig "deur" die draai te verbeter en hulle spoed by die kromming $(1 / r)$ van die betrokke draai aan te pas (figuur 21). Die skerpheid van 'n naderende draai word gepeil deur te kyk of die verdwynpunt van die pad op die draai (figuur 21(a)) beweeg ("oopmaak") of stilstaan. Laasgenoemde geval vereis 'n spoedvermindering deur versigtig te rem of af te rat voor die aanvang van die draai. Om dic uitsig "deur" die draai te verbeter, moet na dic buitekant (punt C) van die draai gestuur word sonder om die padverdelingslyn oor te steek. Sodra "deur" die draai gesien kan word,

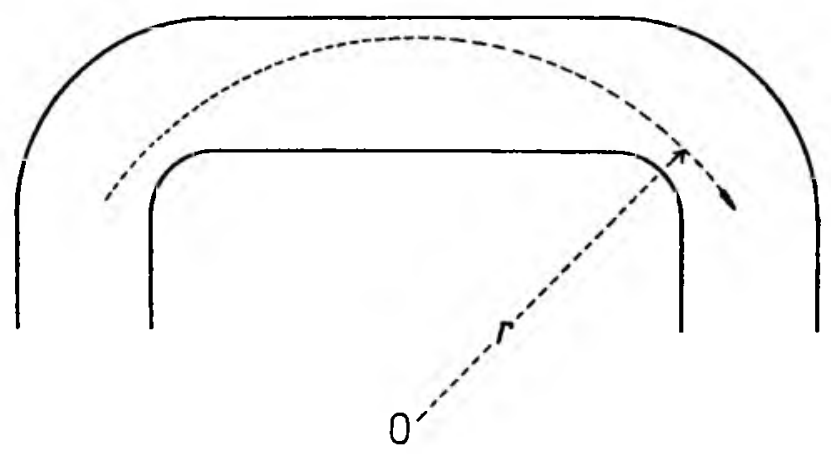

FIGUUR 20: Beweging om 'n draai op 'n renbaan.

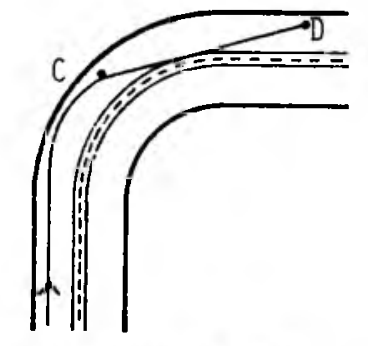

(c) Draai na regs
FIGUUR 21: Aanbevole beweging om in draai op 'n gewome pad. ${ }^{26}$ 
moet so reguit moontlik (lyn $\mathrm{CD}$ ) daardeur gestuur word (figure 21(b) en (c)) om die sentrifugaalkrag op die voertuig tot ' $n$ minimum te beperk, waarna progressief versnel kan word. Alle rem-, stuur- en versnelaksies behoort versigtig en gladweg uitgevoer te word. Ten einde stuurkontrole te behou, moet die voorwiele aanhou rol met behoud van draaimomentum en is dit gevaarlik om skerp rem te trap wanneer ' $n$ voertuig op 'n draai begin uitgly.

\section{DINAMIESE BEHOUDWETTE TYDFNS BOTSING}

Die fisika van botsings word dikwels met die voorbeeld van dié tussen elastiese, sferiese snoekerballe bespreek (figuur 22). ${ }^{17}$ Motorvoertuie as ruimtelike uitgebreide liggame wat vervormbaar en slegs gedeeltelik elasties is, verskil egter hiervan.

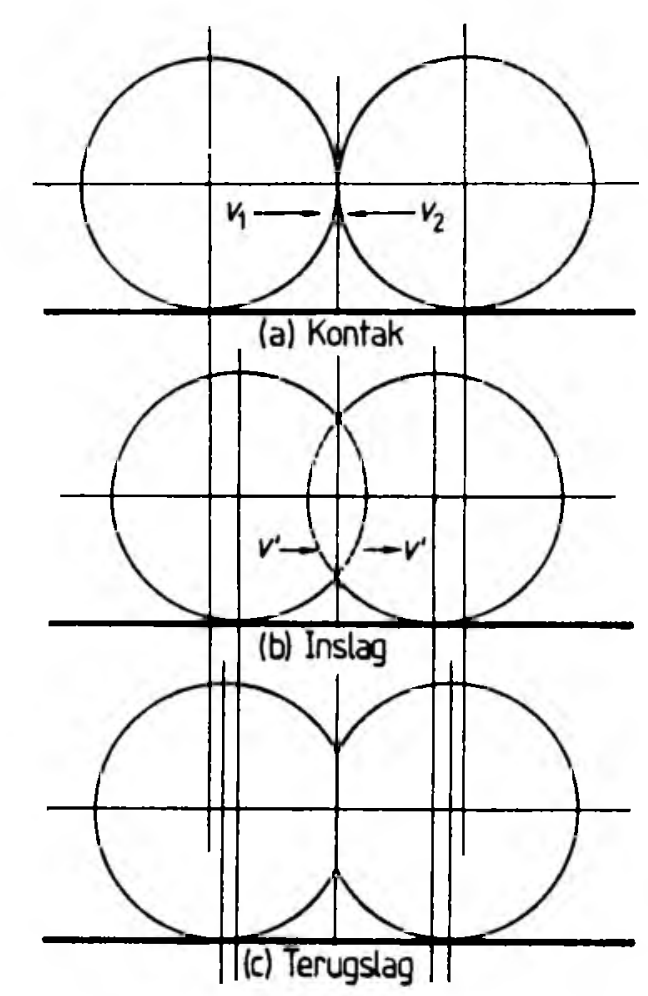

FIGUUR 22: Modelvoorstelling van die drie onderskeibare fases van ' $n$ kop teen kop voertuigbotsing. ${ }^{17}$

\subsection{Momentum en bewegingsenergie}

Die produk van die massa, $m$, en snelheid, $v$, van 'n bewegende voertuig definieer die lineêre momentum daarvan

$$
\vec{p}=m \vec{v}
$$

wat soos die snelheid 'n vektorhoeveelheid met grootte en rigting is. Volgens Newton se tweede bewegingswet kan die krag wat op die voertuig uitgeoefen word, gelyk aan die tempo waarteen sy momentum verander, gestel word. Anders uitgedruk, is die kragimpuls, nl. produk van die krag en tydsduur waaroor dit uitgeoefen word, gelyk aan die momentumverandering van die voertuig:

$$
\vec{F}=\frac{\mathrm{d} \vec{p}}{\mathrm{~d} t} \text { of } \int_{t_{1}}^{t_{2}} \vec{F} \mathrm{~d} t=\Delta \vec{p}
$$

Sulke impulsiewe momentumveranderinge vind tydens skielike versnelling of remming van 'n voertuig of tydens botsing met ' $n$ ander voertuig of voorwerp plaas. Die bot- singskrag wat twee voertuie (sê 1 en 2 ) as 'n geïsoleerde sisteem by die botsingspunt op mekaar uitocfen, is volgens Newton se derde wet van wisselwerking gelyk in grootte. maar teenoorgesteld in rigting:

$$
\vec{F}_{21}=-\vec{F}_{12} \text {. }
$$

Aangesien dic tyd van kontak oftewel botsingstyd, $\Delta t=$ $t_{2}-t_{1}$, dieselfde vir albei voertuie is, volg uit (43) en (44) dat die toename of wins in momentum van die een voertuig (1) gelyk is aan die afname of verlies in momentum van die ander (2):

$$
\Delta \vec{p}_{1}=-\Delta \vec{p}_{2} \text { of } \Delta\left(\vec{p}_{1}+\vec{p}_{2}\right)=0
$$

sodat hulle totale momentum behoue bly, dit wil sê voor en na die botsing dieselfde sal wees:

$\vec{p}_{1}+\vec{p}_{2}=\vec{p}_{1}^{\prime}+\vec{p}_{2}^{\prime}$ of $m_{1} \vec{v}_{1}+m_{2} \vec{v}_{2}=m_{1} \vec{v}_{1}^{\prime}+m_{2} \vec{v}_{2}^{\prime}$.

Hierdie momentumbehoudswet kan gebruik word om die snelhede voor of na (onderskei met aksenttekens) botsing te bereken, indien een stel reeds bekend is, bv. na bepaling uit remsleepmerke (afd. 2.4). Dit vereis geen besonderhede oor die wisselwerking, sons die variasie van die kontakkrag met die botsingstyd, en die aard van die permanente vervorming nie. In die afwesigheid van 'n impulsiewe krag bly die momentum van elke voertuig afsonderlik konstant en beweeg dit teen 'n konstante spoed in 'n reguit lyn, in ooreenstemming met Newton se eerste bewegingswet.

Die kinetiese of bewegingsenergie van ' $n$ bewegende voertuig varieer regeweredig met die massa en kwadraties met die spoed daarvan volgens

$$
E_{k}=\frac{1}{2} m v^{2}=\frac{p^{2}}{2 m} .
$$

In teenstelling met momentumbehoud wat vir alle botsings in die afwesigheid van eksterne kragte geld, bly die totale kinetiese energie van die twee voertuie nie behoue nie, maar verminder weens negatiewe werk om hulle permanent te vervorm:

$$
\begin{gathered}
W=\Delta E_{k}=E_{k}^{\prime}-E_{k}<0 \\
\text { of } \\
\frac{1}{2} m_{1} v_{1}^{2}+\frac{1}{2} m_{2} v_{2}^{2}>\frac{1}{2} m_{1} v_{1}^{\prime 2}+\frac{1}{2} m_{2} v_{2}^{\prime 2} .
\end{gathered}
$$

\subsection{Sentriese botsings met slegs translasie}

Dit is gevalle soos in figuur 23, wanneer twee vocrtuie met hulle swaartepunte $S_{1}$ en $S_{2}$ in lyn met die een of albei se bewegingsrigting bots, sodat hulle nie roteer nie en gou langs die oorspronklike bewegingslyn tot rus kom.
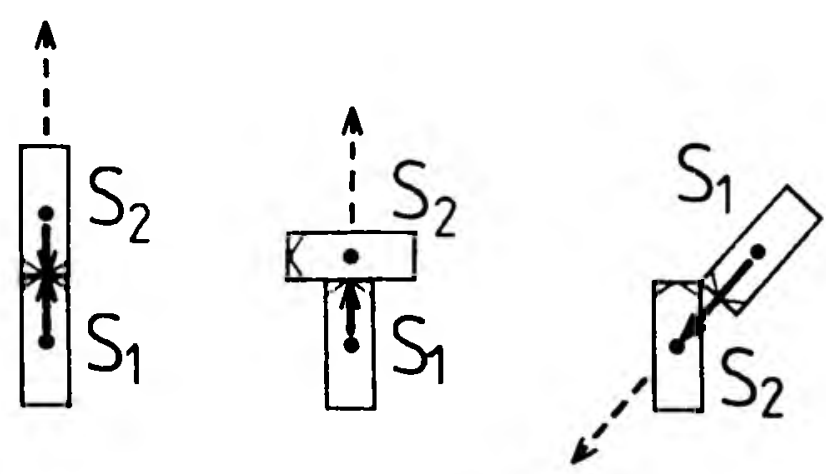

FIGUUR 23: Sentriese botsing van voertuie met swaartepunt in lyn met die bewegingsrigting (geen draaiing). ${ }^{2 l}$ 
(a) Reglynige botsings: Dit is gevalle waar die twee voertuie voor en na botsing langs dieselfde reguitlyn deur hul massamiddelpunte beweeg. Die momentumbehoudswet (46) vereenvoudig dan tot die algebraise eendimeasionele beskrywing

$$
m_{1} v_{1} \pm m_{2} v_{2}=m_{1} v_{1}+m_{2} v_{2}^{\prime} .
$$

waar onderskei word tussen 'n kop teen stert (boonste + teken) en kop teen kop (onderste - teken) botsing. Hieruit volg dat die snelhede van die voertuic omgekeerd eweredig met hulle massas verander:

$$
\frac{\Delta v_{1}}{\Delta v_{2}}=\frac{v_{1}^{\prime}-v_{1}}{v_{2}^{\prime}-v_{2}}=\neq \frac{m_{2}}{m_{1}}\left(\theta=0^{\circ} \text { en } 180^{\circ}\right),(
$$

sodat die voertuig met groter massa 'n kleiner snelheidsverandering ondervind. Dic bewegingsrigting van die een met kleiner massa keer om tydens 'n kop teen kop botsing indien huile voor botsing ongeveer dieselfde spoed $\left(v_{1} \approx v_{2}\right)$ gehad het. Wanneer sulke voertuie $\left(m_{1} \neq m_{2}\right)$ oombliklik na 'n kop teen kop botsing tot rus kom $\left(v_{1}^{\prime}=0=v_{2}^{\prime}\right)$, sal hul aanvanklike momenta mekaar moet uitwis:

$$
m_{1} v_{1}=m_{2} v_{2} \text { of } \frac{v_{2}}{v_{1}}=\frac{m_{1}}{m_{2}} \text {. }
$$

wat gebruik kan word om die een se aanvanklike spoed in terme van die ander s'n (indien bekend) te bereken. So byvoorbeeld vir twee voertuic met massas 1050 en $1500 \mathrm{~kg}$, is hierdie verhouding 0,7 sodat die spoed van die swalarder voertuig voor botsing $70 \mathrm{~km} / \mathrm{h}$ was indien dié van die ligter voertuig $100 \mathrm{~km} / \mathrm{h}$ was

Dit is gerieflik ${ }^{17} \mathrm{om}$ die kontak tydens botsing in twee fases te verdeel. Dic voorwaartse impak of inslag geskied vanaf die tydstip wanneer die twee voertuic mekaar tref en met indringing langs hulle oorspronklike pad bly beweeg, totdat hulle spoed tot $\nu^{\prime}$ gelykgemaak is en die botsingskrag inet toename in kontakoppervlak tot 'n piekwaarde gegroei het. Dit word gevolg

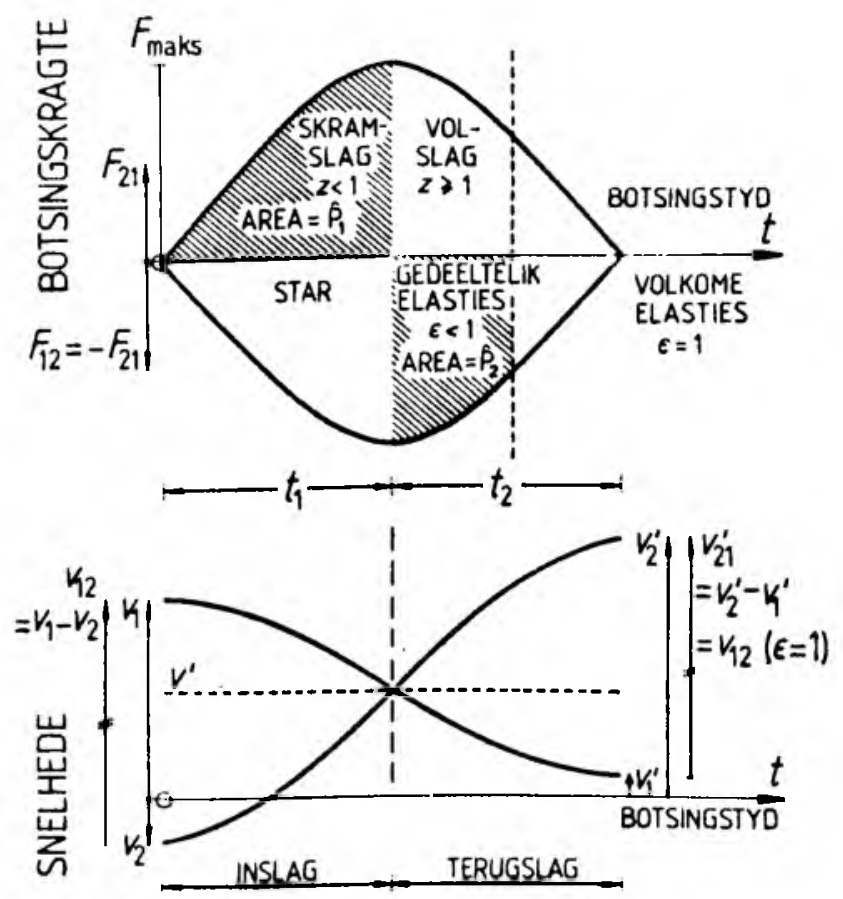

FIGUUR 24: Verandering van botsingskragte en snelhede tydens 'n kop teen kop botsing. ${ }^{17}$ deur die terugbons of terugslag in die geval van nievolkome, starre liggame, wanneer die reaksiekrag die liggame skei, sodat die een se spoed hoër en die ander s'n laer as $\iota^{\prime}$ word. Hierdic verandering in die botsingskragte en voertuigsnelhede word grafies as lunksies van die botsingstyd in figuur 24 voorgestel. Die area onder die $F-t$ grafiek verteenwoordig die impulsiewe momentumverandering (43). Die momentumbehoudwet (49) kan uitgebrei word tot

$m_{1}\left(v_{1}-v^{\prime}\right) \pm m_{2}\left(v^{\prime}-v_{2}\right)=m_{1}\left(v_{1}-v\right)+m_{2}\left(v_{2}-v^{*}\right)$

om die voorwaartse (links) $\hat{P}_{1}$ - en terugwaartse (regs)

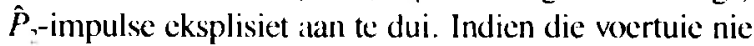
atan mekaar bly kleef gedurende die volle eerste fase nie en dus nie hulle gemeenskaplike spoed " bereik nie, soos dikwels die geval vir skrams botsings by kruisings of met fietsryers, is dit 'n gedeeltelike slag of impak wat $k$ wantitatief uitdrukbaar is in terme van die verhoudingsgetal

$$
z_{1}=\frac{v_{1}}{v^{N}} \text { of } z_{2}=\frac{v_{2}}{v^{*}} \text {. }
$$

Die elastisiteitsgraad van die tweede fase word weer kwantitaticf beskryf in terme van die restitusiekoëffisiënt of botsingsgetal, wat gedefinieer word as dic verhouding van die terugwaartse tot voorwaartse slagimpulse uit (52), of die relatiewe snelhede na en voor botsing:

$$
\varepsilon=-\frac{v_{12}^{\prime}}{v_{12}}=\frac{v_{2}^{\prime}-v_{1}^{\prime}}{v_{1} \neq v_{2}} .
$$

Waardes hiervan wissel tussen $\varepsilon=1$ vir 'n volkome elastiese botsing waar daar geen permanente vervorming of bewegingsenergieverlies is nic $\left(E_{k}=E_{\nu}\right)$; en $\varepsilon=0$ tydens 'n volkome onelastiese botsing waartydens permanente vervorming ten koste van 'n verlies in kinetiese energie $\left(E_{k}<E_{k}\right)$ plaasvind en die botsingvoorwerpe tot 'n eenheid $\left(v_{l}^{\prime}=v_{2}^{\prime}=v^{\prime}\right)$ na botsing koppel. Beraamde waardes uit gekontroleerde motorbotsings verkry, is 0,84 by $16 \mathrm{~km} / \mathrm{h} ; 0,47$ by $32 \mathrm{~km} / \mathrm{h}$ en 0 by 40 $\mathrm{km} / \mathrm{h}$ en hoër. ${ }^{27}$

In die geval van "n reglynige, onelastiese botsing kan die gemeenskaplike snelheid net na botsing bereken word uit momentumbehoud (49) volgens.

$$
v=\frac{m_{1} v_{1} \pm m_{2} v_{2}}{m_{1}+m_{2}} \quad(\varepsilon=0)
$$

mits die snelhede voor botsing (bv. uit wielsleepmerke volgens afd 2.4 bepaal) en voertuigmassas bekend is. Indien laasgenoemde gegewens konstant gehou word, sal $v$ groter wees in 'n kop teen stert as in 'n kop teen kop botsing. Die rigting van $"$ " in laasgenoemde geval word deur die oorheersende momentum van voertuig 1 of 2 bepaal. So byvoorbeeld vir ' $n$ vragmotor met $m_{1}$ $=10000 \mathrm{~kg}$ en $v_{1}=50 \mathrm{~km} / \mathrm{h}$ wat teen 'n motor met $m_{2}=1500 \mathrm{~kg}$ en $v_{2}=100 \mathrm{~km} / \mathrm{h}$ bots, lewer $(55) v^{\prime}$ $=57 \mathrm{~km} / \mathrm{h}$ en $30 \mathrm{~km} / \mathrm{h}$ in die vragmotor se rigting, en (48) die relatiewe bewegingsenergieverkwisting, $\frac{\Delta E_{k}}{E_{k}}=8$ en $73 \%$, respektiewelik vir 'n kop teen stert en kop teen kop botsing.

(b) Skuinshoekige botsing: Gestel soos in figuur 25 dat die twee voertuie teen 'n hoek $\theta$ tussen hulle oorspronklike bewegingsrigtings bots en uiteindelik by eindposisies met hoekoriëntasies $\theta_{1}^{\prime}$ en $\theta_{2}^{\prime}$ respektiewelik tot rus kom. Weens hulle vektoraard word die snelhede en 


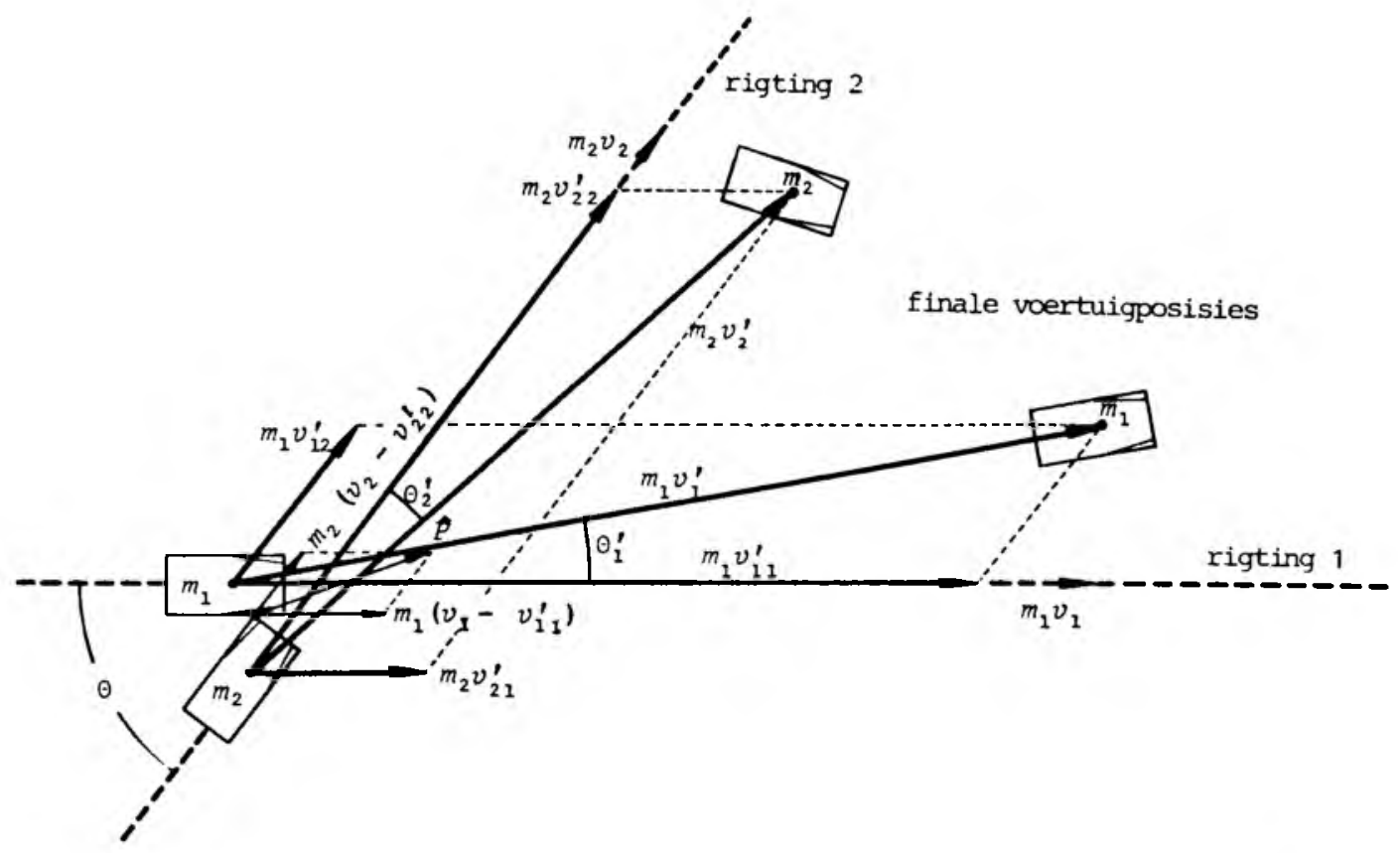

FIGUUR 25: Momentumvektor- en kragimpulsdiagram vir 'n skuinshoekige botsing. ${ }^{17}$

momenta na botsing in twee komponente langs die twee oorspronklike bewegingsrigtings ontbind. Elke voertuig probeer om sy bewegingsrigting aan die ander een af te dwing, bv. voertuig 1 versnel 2 tot spoed $v_{21}^{\prime}=v_{2}^{\prime} \sin \theta_{2}^{\prime}$ in sy oorspronklike rigting, terwyl sy eie spoed van $v_{1}$ tot $v_{11}=v_{1}^{\prime} \cos \theta_{1}^{\prime}$ verminder. Momentumbehoud word afsonderlik in die twee oorspronklike rigtings bevredig volgens

$$
\begin{aligned}
& m_{1}\left(v_{1}-v_{11}^{\prime}\right)=m_{2} v_{21}^{\prime}-m_{2}\left(v_{2}-v_{22}^{\prime}\right) \cos \theta \\
& m_{2}\left(v_{2}-v_{22}^{\prime}\right)=m_{1} v_{12}^{\prime}-m_{1}\left(v_{1}-v_{11}^{\prime}\right) \cos \theta .
\end{aligned}
$$

Kombinasie en herrangskikking hiervan lewer die groottes van die botsingsnelhede as funksies van bepaalbare voertuigmassas, spoede na botsing (uit wielsleepmerke) en hoeke:

$$
\begin{aligned}
v_{1} & =v_{11}^{\prime}+\frac{m_{2} v_{21}^{\prime}-m_{1} v_{12}^{\prime} \cos \theta}{m_{1}\left(1-\cos ^{2} \theta\right)} \\
& =v_{1}^{\prime} \cos \theta_{1}^{\prime}+\frac{m_{2} v_{2}^{\prime} \sin \theta_{2}^{\prime}-m_{1} v_{1}^{\prime} \sin \theta_{1}^{\prime} \cos \theta}{m_{1}\left(1-\cos ^{2} \theta\right)} \\
v_{2} & =v_{22}^{\prime}+\frac{m_{1} v_{12}^{\prime}-m_{2} v_{21}^{\prime} \cos \theta}{m_{2}\left(1-\cos ^{2} \theta\right)} \\
& =v_{2}^{\prime} \cos \theta_{2}^{\prime}+\frac{m_{1} v_{1}^{\prime} \sin \theta_{1}^{\prime}-m_{2} v_{2}^{\prime} \sin \theta_{2}^{\prime} \cos \theta}{m_{2}\left(1-\cos ^{2} \theta\right) .}
\end{aligned}
$$

Die linkerkante van (56) defimieer die kragimpulse wat elke voertuig in sy bewegingsrigting op die ander een tydens botsing uitoefen en wat in momenta omgeskakel word. Vektorsommasie daarvan (figuur 25) lewer die resulterende botsingsimpuls uitgeoefen by die botsingspunt, met grootte

$$
\hat{\boldsymbol{P}}=F t=\sqrt{m_{1}^{2}\left(v_{1}-v_{11}^{\prime}\right)^{2}+m_{2}^{2}\left(v_{2}-v_{22}^{\prime}\right)^{2}} .
$$

Die botsingshoek, $\theta$, kan enige waarde tussen $0^{\circ}$ en $180^{\circ}$ (ekstreme reglynige gevalle, afd $4.2(\mathrm{a})$ ) aanneem. In geval van 'n skerphoekige botsing $\left(0<\theta<90^{\circ}\right.$, $\cos \theta>0$, figuur 25) word elke voertuig se botsingsimpuls deur 'n komponent van die ander voertuig s'n versterk, maar in dié geval van 'n stomphoekige bot sing $\left(90^{\circ}<\theta<180^{\circ}, \cos \theta<0\right)$ vind verswakking weer plaas. In die geval van 'n reghoekige botsing ( $\theta$ $=90^{\circ}, \cos \theta=0$ ) wat algemeen by straatkruisings voorkom, vereenvoudig (57) en (58) respektiewelik tot

$$
\begin{aligned}
& v_{1}=v_{\mathrm{II}}^{\prime}+\frac{m_{2} v_{21}^{\prime}}{m_{1}}=v_{1}^{\prime} \cos \theta_{1}^{\prime}+\frac{m_{2}}{m_{1}} v_{2}^{\prime} \sin \theta_{2}^{\prime} \\
& \quad\left(\theta=90^{\circ}\right) \\
& v_{2}=v_{22}^{\prime}+\frac{m_{1} v_{12}^{\prime}}{m_{2}}=v_{2}^{\prime} \cos \theta_{2}^{\prime}+\frac{m_{1}}{m_{2}} v_{1}^{\prime} \sin \theta_{1}^{\prime}
\end{aligned}
$$

en

$$
\hat{P}=\sqrt{m_{1}^{2} v_{12}^{\prime 2}+m_{2}^{2} v_{21}^{\prime}} \quad\left(\theta=90^{\circ}\right) .
$$

Beskou as voorbeeld ' $\mathrm{n}$ reghoekige botsing met $m_{1}=$ $1000 \mathrm{~kg}$ en $m_{2}=1500 \mathrm{~kg}$, waarna die voertuie glytot-rus-merke van lengtes $s_{1}=8,44 \mathrm{~m}$ en $s_{2}=4,75$ $\mathrm{m}$ teen hoeke $\theta_{1}^{\prime}=30^{\circ}$ en $\theta_{2}^{\prime}=20^{\circ}$ op 'n gelyk pad met wrywingskoëffisiënt $\mu=0,75$ agterlaat. Die spoede net na botsing volg uit glyformule (14) as $v_{1}^{i}=40$ $\mathrm{km} / \mathrm{h}$ en $v_{2}^{\prime}=30 \mathrm{~km} / \mathrm{h}$; die spoede net voor botsing uit (59) as $v_{1}=50 \mathrm{~km} / \mathrm{h}$ en $v_{2}=41,5 \mathrm{~km} / \mathrm{h}$; die resulterende botsingsimpuls uit (60) as $\hat{P}=9,1 \mathrm{kN} \mathrm{s}$; en die vervormingswerk uit (48) as $W=\Delta E_{k}=82,5$ $\mathrm{kJ}$ weens 'n $42 \%$-afname in kinetiese energie.

Bogenoemde uitdrukkings geld vir alle grade van impak: vol of skrams en star of elasties. In die geval van 'n starre volslag het die snelhede van die voertuie na botsing dieselfde grootte, $v_{1}^{\prime}=v_{2}^{\prime}$ (asook $v_{21}^{\prime}=v_{11}^{\prime}$ en $v_{12}^{\prime}=v_{22}^{\prime}$ ) en is parallel, dit wil sê die twee voertuie kom in naasliggende posisies tot rus, soos die maklikste bewys kan word vir die reghoekige geval (59)

$$
\frac{v_{1}}{v_{2}}=\frac{m_{2}}{m_{1}} \frac{v_{11}^{\prime}}{v_{22}^{\prime}}\left(\theta=90^{\circ}, z \geq 1\right) \text {. }
$$

In 'n skrams botsing bereik elke voertuig nie die ander een se eindspoed nie

$$
v_{21}^{\prime}<v_{11}^{\prime} \text { en } v_{12}^{\prime}<v_{22}^{\prime}(z<1)
$$


en kom ook nie in naasliggende posisies tot rus nie, maar elkeen nader aan sy eie oorspronklike bewegingsrigting as aan dié van die ander een waarteen dit gebots het. In die seldsame geval van 'n volkome elastiese voltrefslag sal weer

$$
v_{21}^{\prime}>v_{11}^{\prime \prime} \text { en } v_{12}^{\prime}>v_{22}^{\prime}(\varepsilon=0, z \geq 1)
$$

4.3 Eksentriese botsings met draaibeweging of spin Voertuie wat met hulle massamiddelpunte $S_{1}$ en $S_{2}$ uit lyn bots, ondervind eksentriese kragte wat hulle daaromheen laat draai na botsing soos in figuur 26. Die draairigting hang af van die posisic waar dic eksentriese krag relaticf tot die massamiddelpunt uitgeoefen word: as die botsingskontak byvoorbecld op die linkerkant is, sal die vrye regterkant aanhou beweeg en die draaisin bepaal. Die verset van 'n voertuig teen draaiing word in terme van sy polare traagheidsmoment uitgedruk, nl. die produk van sy massa (veronderstel eweredig oor die wiele versprei) met die $k$ wadraat van die radiale afstand vanaf die swaartepunt $S$ :

$$
I_{s}=m r^{2}=m\left(\frac{b^{2}+d^{2}}{4}\right) .
$$

Met tipiese waardes (kyk na tabel 1, Saayman ${ }^{13}$ ) vir die massa, $m$, asafistand, $b$, en spoorwydte, $d$, ingestel, lewer (64) $I_{s}=2900-7000 \mathrm{~kg} \mathrm{~m}^{2}$ vir 'n klein tot groot passasiersmotor, wat 2,5 keer soveel as vir 'n soliede sfeer (snoekerbal) van dieselfde radius is.

Beskou nou 'n eenvoudige geval in figuur 27 waar voertuig 1 met snelheid, $v_{1}$, eksentries teen stilstaande voertuig 2 bots sodat dit 'n gekombineerde beweging uitvoer, nl. translasie van sy massamiddelpunt langs die pad,
$S_{2}-S_{2}^{\prime}-S_{2}^{\prime \prime}$, en rotasic deur 'n hoek, $\theta\left(=90^{\circ}\right.$ getoon), om 'n as deur sy massamiddelpunt. Die draaimoment weens die botsingskrag, $F$, wat by die kontakpunt oor 'n radiale afstand, $r$, vanaf $S_{2}$ werk

$$
\tau=F r,
$$

sal verander soos $F$ (kyk figuur 24) en moontlik ook $r$ (weens vervorming) tydens kontak verander. Dit veroorsaak volgens Newton se rolasiewet

$$
\tau=\frac{\mathrm{d} L}{\mathrm{~d} t}=l \alpha \text { of } \int_{t_{1}}^{t_{2}} \tau \mathrm{d} t=\Delta L
$$

'n hoekversnelling, $\alpha=\frac{\mathrm{d} \omega}{\mathrm{d} t}=\frac{\mathrm{d}^{2} \theta}{\mathrm{d} t^{2}}$, of hockimpuls,

$\int_{t_{1}}^{2} \tau \mathrm{d} t$, wat die voertuig laat draai met ' $n$ wins in hoekmomentun

$$
L=I \omega=\left(m r^{2}\right)\left(\frac{v}{r}\right)=m v \bar{r} .
$$

waar 'n gemiddelde hefboomarm, $\bar{r}$, gebruik word vir gevalle van vervorming. Die momentumbehoudswet tydens botsings kan uitgebrei word om vir sowel translasie as rotasie voorsiening te maak:

$$
\begin{array}{r}
m_{1}\left(v_{1}-v_{1}\right)=m_{2} v_{2}^{\mu} \text { (translasie) }+\frac{I_{2} \omega_{2}}{\bar{r}_{2}} \text { (rotasie) } \\
=m_{2}\left(v_{2}^{\mu}+\frac{r^{2} \omega^{2}}{\bar{r}}\right)=m_{2} v_{2} .
\end{array}
$$

Die "virtuele eindspoed" van voertuig 2

$$
v_{2}=v_{2}^{\prime \prime}+\frac{r^{2} \omega^{2}}{\bar{r}}
$$

kan bepaal word deur die wrywingswerk tydens die swaaiglybeweging van die wiele aan die residuele bewegingsener-
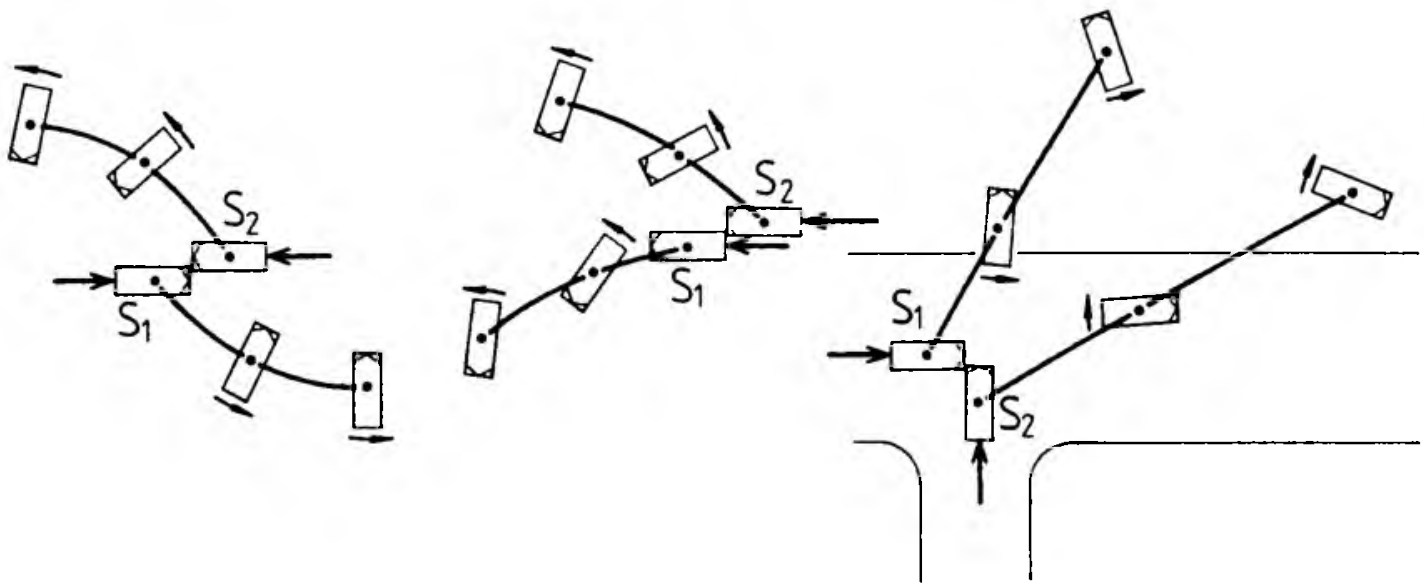

FIGUUR 26: Skrams botsings van voertuie wat eksentriese kragte skep, met gevolglike draaiing om hulle swaartepunte.

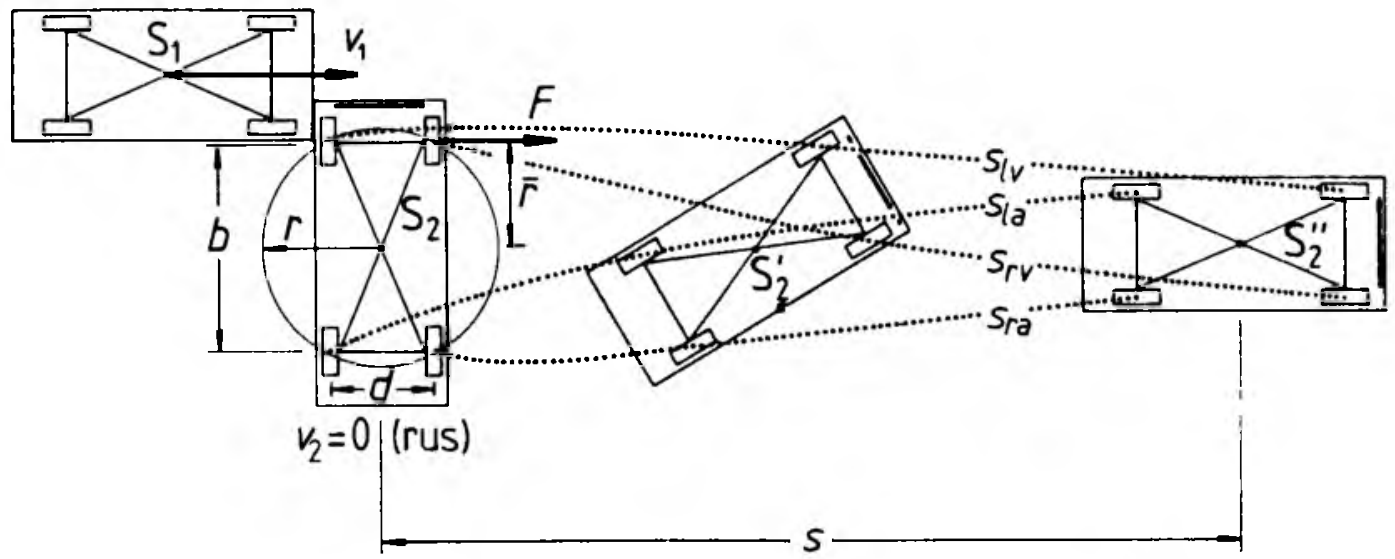

FIGUUR 27: Direkte eksentriese botsing met tol deur $90^{\circ} .17$ 
gie gelyk te stel:

$$
W=f \bar{s}=\mu m_{2} g \vec{s}=\frac{1}{2} m_{2} v_{2}^{2}
$$

sodat

$$
v_{2}=\sqrt{2 \mu g \bar{s}} .
$$

Die gemiddelde geboë glymerklengte

$$
\bar{s}=\frac{s_{n}+s_{r a}+s_{k}+s_{t u}}{4}
$$

kan direk deur meting bepaal word, of andersins geometries as funksie van die draaihoek benader word as

$$
\bar{s}(\theta)=\sqrt{s^{2}+\left(\frac{\theta}{90^{\circ}}\right)^{2} r^{2}},
$$

waar die reglynige translasieafstand $s<\bar{s}$ van swaartepunt $\mathrm{S}_{2}$ ook direk in glyformule (14) gebruik kan word om die translasiespoed $v_{2}^{\prime \prime}$ te bepaal.

Die bewegingsenergie kan ook in twee komponente weens translasie en rotasie verdeel word volgens

$\frac{1}{2} m_{2} v_{2}^{2}=\frac{1}{2} m_{2} v_{2}^{\mu 2}$ (translasie) $+\frac{1}{2} l_{2} \omega_{2}^{2}$ (rotasie),

waaruit die hoeksnelheid berekenbaar is as

$$
\omega_{2}=\sqrt{\frac{m_{2}}{I_{2}}\left(\nu_{2}^{\prime 2}-v_{2}^{\prime \prime 2}\right)}=\sqrt{\frac{v_{2}^{\prime 2}-v_{2}^{\prime 2}}{r^{2}}} .
$$

Die residuele spoed $v_{1}$ van voertuig 1 kan op soortgelyke wyse uit sy geboë glymerke bepaal word (nie aangetoon op figuur 27 nie) sodat die botsingspoed $v_{1}$ uit die ekwivalent van behoudswet (68) bepaalbaar is.

\subsection{Botsingstye en -versnellings}

Wanneer twee voertuie (hipoteties sferies voorgestel ${ }^{17}$ ) kop teen kop soos in figuur 28 bots, ondergaan hulle vervorming by die botsingspunt sodat hul massamiddelpunte oor afstande $s_{1}^{\prime}$ en $s_{2}^{\prime}$ verplaas word, afhangende van hoe sag en onbuigsaam (soos plastiek) of hard en buigsaam (soos metaal) hul materiaal is. Hoe harder en onbuigsamer die materiaal, hoe korter is hierdie primêre inslagverplasing en hoe groter is die botsingskrag. Hoe meer elasties die botsing is, hoe groter is die sekondêre terugslag sodat die botsingspad verkort word met die terugslagafstande $s_{1}^{4}$ en $s_{2}^{\prime \prime}$ om die resulterende botsingspaaie

$$
s_{1}=s_{1}^{\prime}-s_{1}^{\prime \prime} \text { en } s_{2}=s_{2}^{\prime}-s_{2}^{\prime \prime}
$$

te lewer. Dit moet onderskei word van die vervormingspaaie

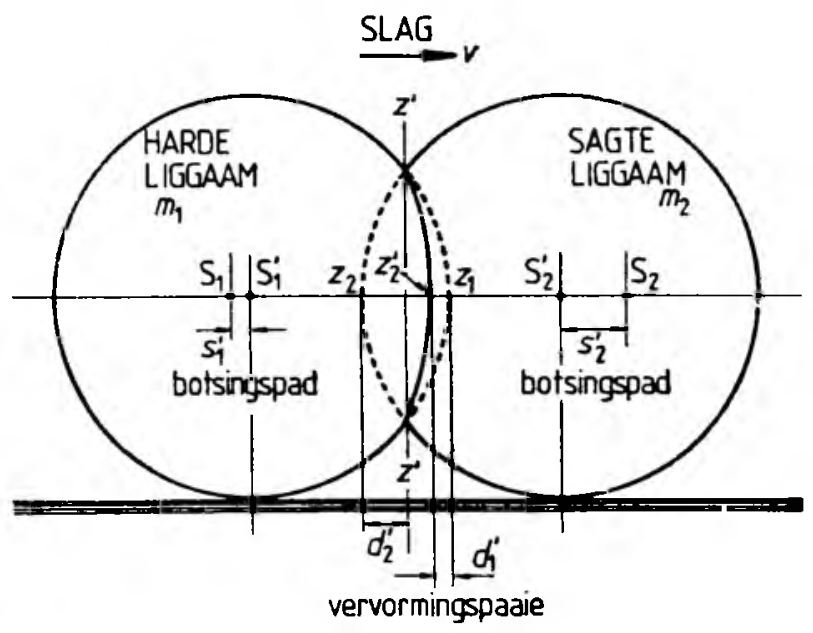

FIGUUR 28: Verband tussen die botsings- en vervormingspaaie tydens 'n kop teen kop botsing. ${ }^{17}$

$$
d_{1}^{\prime}=z_{1}-z_{2}^{\prime} \text { en } d_{2}^{\prime}=z_{2}-z_{2}^{\prime} .
$$

bv. klein $d_{1}^{\prime}$ vir 'n harde liggaam soos 'n swaardiensvragmotor en groot $d_{2}^{\prime}$ vir 'n sagter liggaam soos 'n passasiersmotor (soos geskets in figuur 28). Hulle verwantskap is

$$
s_{1}^{\prime}+s_{2}^{\prime}=d_{1}^{\prime}+d_{2}^{\prime} \text { waar } s_{1}^{\prime} \neq d_{1}^{\prime} \text { en } s_{2}^{\prime} \neq d_{2}^{\prime}(78)
$$

Uit figuur 22(a) en (b) volg dat verplasings $s_{1}^{\prime}$ en $s_{2}^{\prime}$ respektiewelik teen gemiddelde spoede

$$
\bar{v}_{1}=\frac{v_{1}+v^{\prime}}{2} \text { en } \bar{v}_{2}=\frac{v_{2}+v^{\prime}}{2}
$$

afgelê word, sodat die eerste botsingstyd tydens volle inslag

$$
t_{1}=\frac{s}{\bar{v}}=\frac{s_{1}+s_{2}}{\bar{v}_{1} \mp \bar{v}_{2}}=\frac{2\left(d_{1}+d_{2}\right)}{v_{1} \mp v_{2}},
$$

waar die dubbelteken in die noemer vir 'n kop teen stert $(\rightarrow)$ en kop teen kop botsing $(+)$ voorsiening maak. Die tweede botsingstyd tydens elastiese terugslag met permanente vervorming, $d=d_{1}+d_{2}$, is

$$
t_{2}=\frac{2(s-d)}{v_{1}^{\prime}+v_{2}^{\prime}},
$$

wat relatief tot die eerste tyd uitgedruk word as

$$
\frac{t_{2}}{t_{1}}=\left(\frac{s-d}{s}\right) \frac{v_{1} \mp v_{2}}{v_{1}^{\prime}+v_{2}^{\prime}}=\varepsilon \frac{v_{1} \mp v_{2}}{v_{1}^{\prime}+v_{2}^{\prime}}=\frac{v_{2}^{\prime}-v_{1}^{\prime}}{v_{1}^{\prime}+v_{2}^{\prime}},
$$

na gebruik van die botsingsgetal (54). Die totale botsingstyd vir 'n elastiese impak is dan

$$
t=t_{1}+t_{2}=\frac{2 v_{2}^{\prime}}{v_{1}^{\prime}+v_{2}^{\prime}} t_{1}
$$

en die vertraging (negatiewe versnelling) as gevolg van die botsing is

$$
a=\frac{v^{\prime}-v}{t} .
$$

Vir twee voertuie wat byvoorbeeld teen $30 \mathrm{~km} / \mathrm{h}$ nie-elasties kop teen kop bots, wedersyds mekaar $d_{1}+d_{2}^{\prime}=0,40 \mathrm{~m}$ indring en tot rus kom, lewer ${ }^{17}$ dit $t=t_{1}=0,05 \mathrm{~s}$ en $a$ $167 \mathrm{~m} / \mathrm{s}^{2}=17 \mathrm{~g}$, wat binne die omvang van empiriese vertragings van $5-55 g$ is, in vergelyking met $0,75 g$ vir noodremming op 'n droë, growwe teerpad.

\subsection{Botsingswerk}

Die kragte wat tydens botsing ontstaan, word langs die botsingspad uitgeoefen en verrig werk tydens vervorming wat gelyk is aan die verandering in bewegingsenergie tydens spoedafname:

$$
W=F s=\Delta E_{k} .
$$

Dit is in twee komponente verdeelbaar, nl. eerstens negatiewe werk tydens inslag totdat die gemeenskaplike spoed, $v^{\prime}$, bereik is

$$
W_{1}=\frac{1}{2}\left[m_{1} v_{2}^{2}+m_{2} v_{2}^{2}-\left(m_{1}+m_{2}\right) v^{2}\right]=\frac{1}{2} \mu v_{12}^{2}<0,
$$

en tweedens positiewe werk tydens terugslag wanneer die kinetiese energie gedeeltelik herwin word

$W_{2}=\frac{1}{2}\left[m_{1} v_{1}^{\prime 2}+m_{2} v_{2}^{2}-\left(m_{1}+m_{2}\right) v^{12}\right]=\frac{1}{2} \mu v_{12}^{\prime 2}>0$.

Die effektiewe botsingwerk volgens die Carnot-vergelyking

$$
\begin{aligned}
W=W_{1}-W_{2} & =\frac{1}{2} m_{1}\left(v_{1}^{2}-v_{1}^{2_{2}}\right)+\frac{1}{2} m_{2}\left(v_{2}^{2}-v_{2}^{12}\right) \\
& =\frac{1}{2} \mu v_{12}^{2}\left(1-\varepsilon^{2}\right),
\end{aligned}
$$


warin die gereduseerde massa van die twee voertuic asof hulle as 'n eenheid beweeg, gedefinieer word as

$$
\mu=\frac{m_{1} m_{2}}{m_{1}+m_{2}},
$$

en die relatiewe snelheid, $v_{12}=v_{1} \mp v_{2}$, soos voorheen. Uit (88) blyk dat dit toeneem soos die elastisiteit afneem en 'n maksimum vir 'n volkome onelastiese botsing $(\varepsilon=$ 0 ) bereik. Hierdie verlies aan bewegingsenergic word omgesit na wrywing, hitte, elektrisiteit, vibrasies (in alle tipes botsings) en permanente vervorming (in gedecltelike elastiese botsings). Indien die botsing skuins met hoek $\alpha$ tussen die kragwerklyn en voertuigas plaasvind, word die vervormingsenergic met 'n faktor $\left(1+\tan ^{2} \alpha\right)$ versterk weens skuurwrywing tussen die voertuie. ${ }^{28}$

\section{FISIESE HERKONSTRUERING EN ANALISE VAN 'N TIPIESE BOTSING}

Die voorafgaande teorie word nou in 'n botsingswoorbeeld toegepas wat ook die nuttige rol van 'n fisikus in geregtelike ondersoeke illustreer. Wetenskaplike getuienis soos hier uiteengesit, word sedert 1989 op versoek van die staatsatanklaer in die plaaslike landdroshof aangevoer. Soortgelyke voorbeelde wat onder andere ook voetgangers, wat gedurende $198947 \%$ van die sterftesyfer van 10877 op die RSA paaic uitgemaak het, betrek, word elders in oorsese botsingsondersoekhandleidings ${ }^{17,20-22.29}$ bespreek.

\subsection{Situasie}

'n Passasiersmotor A wat van suid na noord op 'n gelyk dubbelpad ry, bots reghoekig by 'n kruising teen 'n afleweringsvoertuig B wat van oos na wes op 'n gelyk enkelbaan ry. Beide voertuie rem teen $75 \%$ doeltreffendheid en gly voor en na botsing.

\subsection{Teenstrydige verklarings deur die bestuurders aan die ondersoekbeampte}

A: "Ek het teen omtrent $60 \mathrm{~km} / \mathrm{h}$ gery toe die afleweringsvoertuig skielik van regs verskyn en teen my vasry. Dit het nie voor die kruising gestop nie. Ek het hard gerem, maar kon nie betyds stilhou nie."

B: "Ek het voor die kruising gestop, gekyk en toc stadig verder gery. Skielik het die passasiersmotor teen 'n hoë spoed van links op my afgepeil en teen my gebots."

\subsection{Metings op ongelukstoneel deur ondersoekbeampte} Lengte van wielsleepmerke:

voor botsing: $\quad s_{\mathrm{A}}=9.5 \mathrm{~m} ; \quad s_{\mathrm{B}}=8,0 \mathrm{~m}$ na botsing: $\quad s_{\mathrm{A}}^{\prime}=7,0 \mathrm{~m} ; \quad s_{\mathrm{H}}^{\mathrm{H}}=4,5 \mathrm{~m}$

Finale posisies van voertuie (massamiddelpunt) relatief tot die oos-wes-botsingsposisielyn:

$$
\begin{aligned}
\theta_{\mathrm{A}}^{\prime} & =40^{\circ} ; \quad \theta_{\mathrm{B}}^{\prime}=30^{\circ} \\
\text { Voertuigmassas: } & m_{\mathrm{A}}=1500 \mathrm{~kg} ; m_{\mathrm{B}}=2000 \mathrm{~kg}
\end{aligned}
$$

Wrywingskoëffisiënt tussen bande en teerpad (uit treksleetoets, afd 2.4): $\mu=0,75$

\subsection{Minimum spoedberekeninge deur fisikus}

(a) Net na botsing: uit gly-tot-stop-formule (14) volg

$$
v_{\mathrm{A}}^{\prime} \geq 36,4 \mathrm{~km} / \mathrm{h} \text { en } v_{\mathrm{B}}^{\prime} \geq 29,2 \mathrm{~km} / \mathrm{h}
$$

(b) Net voor botsing: uit momentumbehoud (59) volg
$v_{\mathrm{A}}=v_{\mathrm{A}}^{\prime} \cos \theta_{\mathrm{A}}^{\prime}+\frac{m_{\mathrm{B}}}{m_{\mathrm{A}}} v_{\mathrm{B}}^{\prime} \cos \theta_{\mathrm{B}}^{\prime} \geq 61,6 \mathrm{~km} / \mathrm{h}=17,1 \mathrm{~m} / \mathrm{s}$

$\nu_{\mathrm{B}}=v_{\mathrm{B}} \sin \theta_{\mathrm{B}}^{\prime}+\frac{m_{\mathrm{A}}}{m_{\mathrm{B}}} v_{\mathrm{A}}^{\prime} \sin \theta_{\mathrm{A}}^{\prime} \geq 32,2 \mathrm{~km} / \mathrm{h}=8,9 \mathrm{~m} / \mathrm{s}$

(c) Net voor remming: uit spoedkombinasie (II) met $\theta=$ 0 en $v$ uit (b) ingestel, $\mathrm{nl}$.

$u \geq \sqrt{2 \mu g s+v^{2}}, \operatorname{volg} u_{\mathrm{A}} \geq 74,8 \mathrm{~km} / \mathrm{h}=20,8 \mathrm{~m} / \mathrm{s}$

$$
\text { en } u_{\mathrm{B}} \geq 50.6 \mathrm{~km} / \mathrm{h}=14.1 \mathrm{~m} / \mathrm{s}
$$

\subsection{Herkonstruksie op skaalplan (figuur 29)}

(a) Beginnende by die botsingspunt (B) as "oorsprong" word in ruimte en tyd langs die aantogpaaie van die twee vocrtuie teruggewerk om die gebeure aanleidend tot die botsing te herkonstrueer.

(b) Die handelingspumt $(\mathrm{H})$ is waar vermydingsoptrede soos remming begin, $\mathrm{nl}$. henaderd by die aanvang van die wielsleepmerke voor die botsing by posisies $s_{\mathrm{A}}=$ $9,5 \mathrm{~m}$ en $s_{\mathrm{B}}=8,0 \mathrm{~m}$ en op tydstippe bereken uit $t=\frac{v-u}{a}=\frac{v-u}{-0,75 g}$, nl. $t_{\mathrm{A}}=0,5 \mathrm{~s}$ en $t_{\mathrm{B}}=0,71 \mathrm{~s}$.

(c) Die punt van werklike waarneming (W) is waar en wanneer die bestuurders bewus geword het van die botsingsgevaar, en word deur die reaksietyd, $t_{r}$, en afstand, $s_{r}=u t_{r}$, van die handelingspunt geskei. Indien albei bestuurders 'n vinnige reaksietyd van 0.75 $\mathrm{s}$ het, volg na bytelling by die waardes in (b) dat $t_{\mathrm{A}}=$ $1,25 \mathrm{~s} ; s_{\mathrm{A}}=25,1 \mathrm{~m}$ en $t_{\mathrm{B}}=1,46 \mathrm{~s} ; s_{\mathrm{B}}=18,6 \mathrm{~m}$.

(d) Die vermydingspunr (V) is die posisie en tydstip waarna die botsing weens die fisiese bewegingswette nie meer verhoed kon geword het nie en wat voor of na punt $W$ geleë kan wees. Dit is uit die som van die reaksie- en rem-tot-stilhou-afstande en -tye, vgls. (4) en (5) bepaalbaar, nl. $s_{\mathrm{A}}=45,0 \mathrm{~m} ; t_{\mathrm{A}}=3,58 \mathrm{~s}$ en $s_{\mathrm{B}}$ $=24,1 \mathrm{~m} ; t_{\mathrm{B}}=2.67 \mathrm{~s}$.

(e) Die punt van moontlike waameming (MW) is die verste posisie en vroegste tydstip waar 'n normale persoon van die komende gevaar bewus kon geword het. Dit word deur 'n probeer-en-tref-metode op die skaalplan bepaal deur die langste gesiglyn (sonder enige versperring) tussen opeenvolgende voertuigposisies te trek. Die verskil tussen hierdie punt en dié van werklike waarneming word die waarnemingsvertraging genoem, wat veroorsaak word deur die onwaaksaamheid en afgedwaalde aandag van die bestuurder.

5.6 Analise

Vanaf die skaalplan kan die volgende gevolgtrekkings gemaak word:

(a) Bestuurder $\mathrm{A}$ het, teenstrydig met haar verklaring, die $60 \mathrm{~km} / \mathrm{h}$-spoedgrens aansienlik (amper met $15 \mathrm{~km} / \mathrm{h}$ ) oorskry. Haar aandag het so afgedwaal weens kinders wat voor die skoolgebou gespeel het, dat sy eers 'n afstand, $M W-W=26,1 \mathrm{~m}$, nadat sy al die naderende voertuig $B$ kon gesien het, dit waargeneem het. Toe was sy al 'n afstand, $V-W=19,9 \mathrm{~m}$, verby die punt vanwaar sy kon gerem het om betyds te kon stilhou by die kruising en die ongeluk te kon vermy het.

(b) Bestuurder B het wel binne die spoedgrens gery, maar het die naderende voertuig A eers kort duskant die stilhoulyn gewaar en was dus nie van plan om by dic kruising stil te hou, soos hy beweer het dat hy wel gedoen het nie. Albei bestuurders het dus hier skuld aan die botsing. 


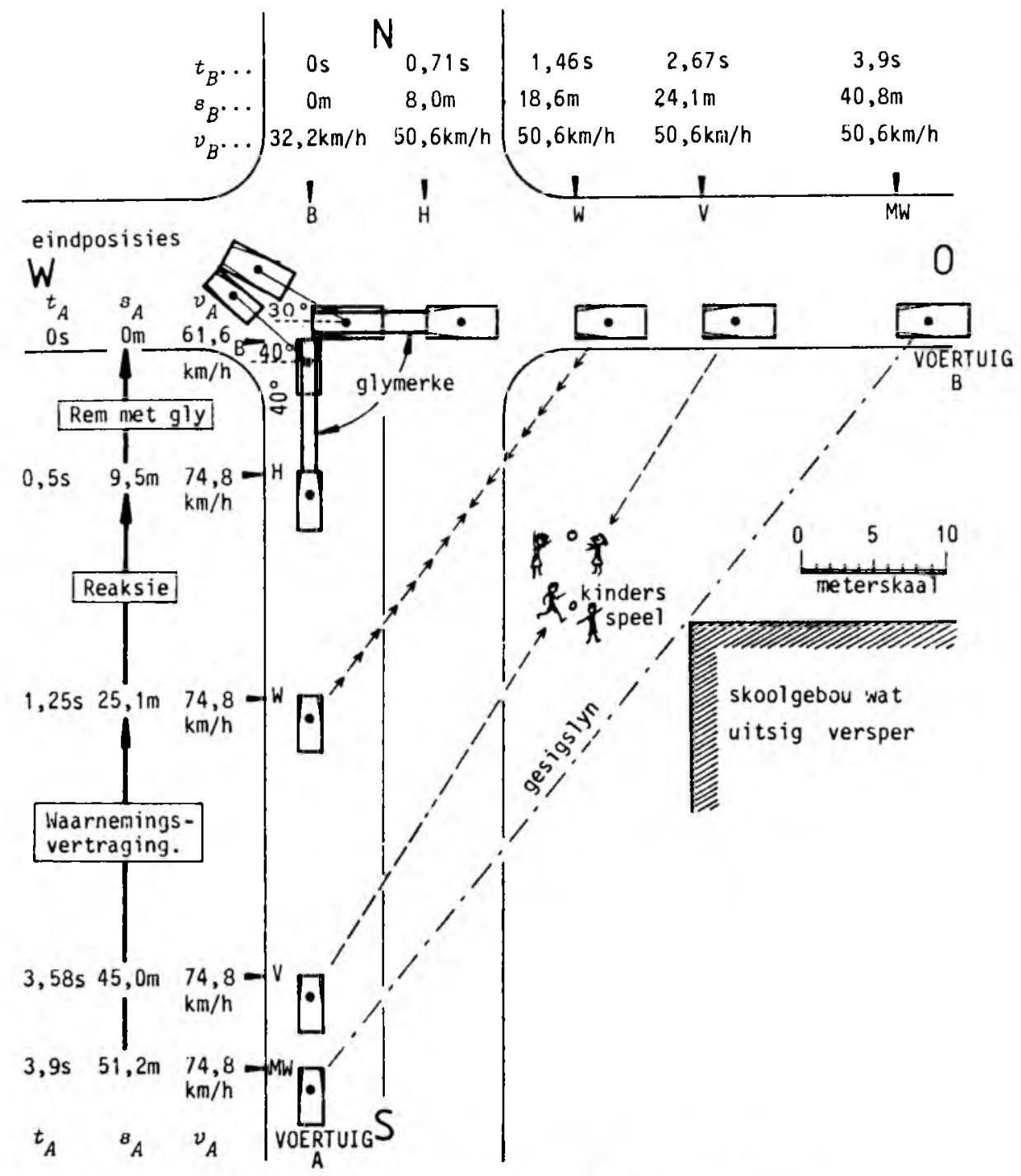

FIGUUR 29: Analise van 'n reghoekige botsing.

\section{VERVORMING: VOERTUIGSKADE EN PASSA- SIERSBESERINGS}

Ten einde motorontwerp te verbeter ten opsigte van minder botsingskade en groter passasiersveiligheid voer motorvervaardigers soos Volkswagen, ${ }^{30}$ Opel en Ford, en navorsinginstansies soos die Suid-Afrikaanse Buro vir Standaarde (vir kontrole oor sitplekgordels), National Road Research Laboratory (NRRL) ${ }^{31}$ in die VK en Calspan Corporation ${ }^{32}$ in die VSA gekontroleerde botsingsimulasies uit. Motors met mensagtige poppe of kadawers as insittendes word met afstandbeheer in betonversperrings vasgejaag, terwyl videokameras die posisieveranderings fotografeer en verskeie elektroniese sensors die spoed, versnelling en spanning op die voertuig en insittendes as funksie van die botsingstyd meet. Van hierdie data word in figure 30 en 31 getoon. Wiskundige modelle word gebou en met behulp van rekenaars ontleed om die invloed van faktore soos spoed, rompversterkings, lugkussings, veiligheidsgordels, ens. op die gedrag van die botsingsisteem te bepaal.

\subsection{Botsingskrag en permanente vervorming}

Wanneer die skade aan 'n voertuig as gevolg van 'n botsing ondersoek word, asook maniere hoe om die insittendes teen beserings te beskerm, is dit belangrik om kennis op te doen oor die kragte wat die bewegende liggame tot rus bring. Die botsingskragte, asook hul aangrypingspunte en paaie, verskil van botsing tot botsing en varieer tydens elke botsing volgens die materiaal, vorm en struktuur van die betrokke voertuie, die wyse en posisie van impak, ens. Hierdie temporale kragverandering is baie kompleks soos die piekvormige figure 30(a) en 31(a) aantoon. Eers maak sagter dele soos die buffers, ligte, wande en deure kontak, wat later gevolg word deur dic harder onderdele soos die raamwerk, asse, vere, hulsels, ens. 'n Groot verskeidenheid van materiale, wat wissel van elasties tot plasties en hard tot bros, tree op sodat die impak nie by 'n enkele nie, maar by verskeie punte en areas gelyktydig begin. 'n Reeks van veranderende en heterogene kragimpulse en gepaardgaande momentumveranderings moet bymekaar getel word volgens die impulsmomentumbeginsel:

$m_{1} v_{1} \pm m_{2} v_{2}=\int_{0}^{1} F \mathrm{~d} t=m_{1} v_{1} \pm m_{2} v_{2}^{\prime}\left(\theta=0\right.$ of $\left.180^{\circ}\right)$,

was wiskundig moontlik is deur die area tussen die $F-t$ grafiek en tydas te bepaal. Deur deling met die botsingstyd, $t=t_{1}+t_{2}$, kan ' $n$ teoretiese gemiddelde botsingskrag, $\bar{F}=\frac{\int_{0}^{1} F \mathrm{~d} t}{t}$, dan bepaal word. Kragimpulse van dieselfde grootte kan vinnig of stadig wees, soos onderskei word deur 'n harde en sagte botsing in figuur 32 . Tydens ' $n$ harde botsing soos van 'n voertuig trompop teen 


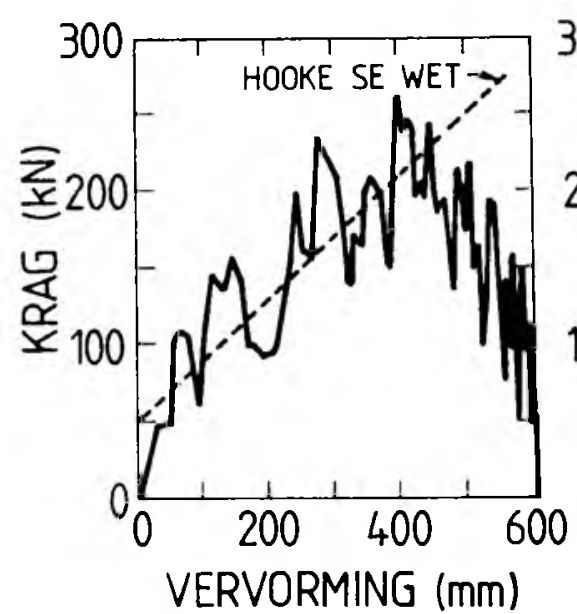

(a) Horisontale botsing van n motor teen $n$ sol iede versperring ${ }^{30}$ )

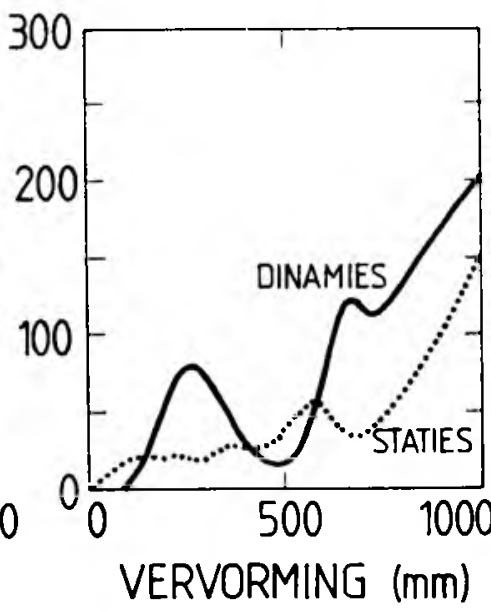

(b) Vertikale botsing van motor teen in soliede versperring ${ }^{23}$ )

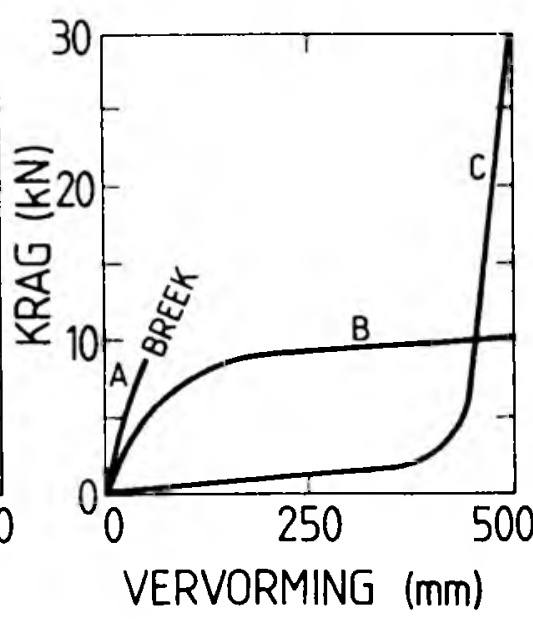

(c) Sitplekgordels ${ }^{3}$ )

FIGUUR 30: Krag-vervormingskenkrommes tydens trompop botsings.
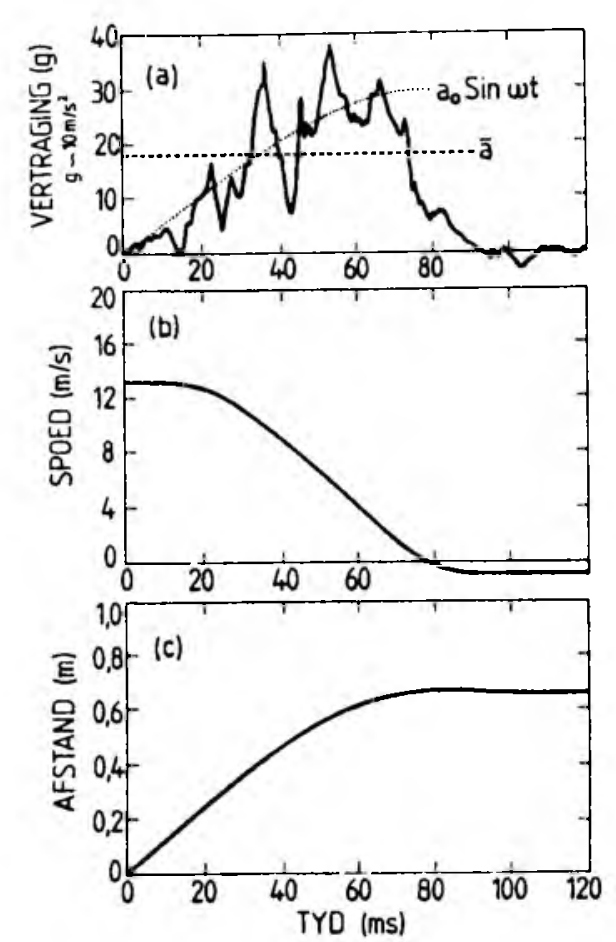

FIGUUR 31: Bewegingsgrafieke vir 'n direkte botsing van 'n VW Golf motor teen 'n soliede versperring. ${ }^{30}$

'n soliede muur word 'n groot maksimum $\mathrm{krag} \sim 10^{5} \mathrm{~N}$ oor 'n baie kort tydsduur van 0,1 s uitgeoefen, met gevolglike groot skade, terwyl 'n sagte botsing met plantegroei langs die pad die botsingskrag oor 'n langer tyd sal uitsprei, met minder nadelige gevolge.

Die grootte van die botsingskrag varieer via die werkenergie-beginsel $(85)$ regeweredig met die voertuigmassa en die kwadraat van sy spoed, en omgekeerd eweredig met die afstand waarbinne die voertuig tot stilstand kom. Die omvang daarvan kan aanskoulik voorgestel word deur die "uitwissing" van die bewegingsenergie tydens 'n horisontale botsing teen spoed, $v$, met 'n stilstaande soliede versperring, gelyk te stel aan die "verlies" in gravitasionalc potensiële energie wanneer dieselfde voertuig uit rus vanaf 'n gebou met hoogte, $h$, val en vertikaal met die grond bots:

$$
\Delta E_{k}=\Delta E_{p} \text { of } i m v^{2}=m g h \text { sodat } h=\frac{v^{2}}{2 g} \text {. }
$$

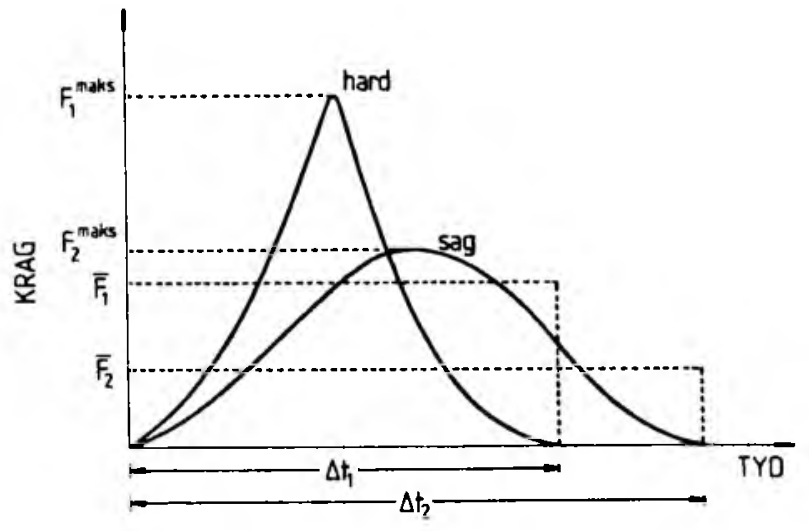

FIGUUR 32: Onderskeid tussen die krag-tyd-grafieke vir 'n harde en sagte botsing.

So byvoorbeeld kan die trefkrag teen 'n spoed, $v=48$ $\mathrm{km} / \mathrm{h}$, vergelyk word met dié wanneer $h=9 \mathrm{~m}$, oftewel 'n voertuig wat vanaf die derde verdieping die grond tref. By 'n drie maal hoër spoed, $\mathrm{nl}$. $144 \mathrm{~km} / \mathrm{h}$, is die vergelykbare hoogte $3^{2}=9$ maal hoër, wat gelykstaande sal wees aan 'n vrye val vanaf die 27 ste verdieping! Mediafotos bevestig dat in 'n trompop konfrontasic tussen 'n swaargelaaide vragmotor en 'n ligte passasiersmotor, laasgenoemde altyd die slegste daarvan afkom, omdat hierdic "sagte liggaam" sowel sy eie as die meeste van die vragmotor se kinetiese energie moet absorbeer (kyk na die vervormingspaaie $d_{2}^{\prime}>d_{1}^{\prime}$ in figuur 28), alhoewel hulle ewe veel momentumverandering ondergaan.

Die ernstigheid van 'n botsing hang egter nie bloot van die trefkraggrootte, $F$, af nie, maar ook van die (loodregte) oppervlakte, $A$, waaroor dit uitgeoefen word, oftewel hulle verhouding, wat die lokale drukspanning, $p=\frac{F}{A}$, genoem word. Hoe groter die drukspanning, hoe groter is die vervorming, $\mathrm{nl}$. dic relatiewe verandering in afmetings van dic voorwerp wat getref word en die skade wat dus aangerig word. Die materiaaleienskappe speel ook 'n belangrike rol, spesifiek die verhouding van die spanning tot die vervorming, wat die elastisiteitsmodulus daarvan definieer. 'n Materiaal kan "sterk" wees in die sin dat dit 'n groot spanning vereis vir ' $n$ bepaalde vervorming of vanweë ' $n$ groot elastisiteitsperk, nl. die maksimum spanning waarna dit permanent vervorm. Die vervorming tydens ' $n$ voertuig- 
botsing is nie 'n eenvoudige magsfunksie van die spanning wanneer die voertuigmateriaal getrek, gedruk, gebuig, gewring, gestamp en versplinter word nie. Dit volg dus nie Hooke se wet op 'n eenvoudige wyse nie, soos uit figuur 30 blyk. Die volgende fenomenologiese eienskappe is egter wel uit botsingsondersoeke afleibaar: ${ }^{17}$

(1) Twee botsingliggame neig om die botsingsproses binne die kortste moontlike tyd, $t_{\min }$, en grootste moontlike $\mathrm{krag}, F_{\text {maks }}$, uit te voer, terwyl elkeen voortdurend sy bewegingsrigting aan die ander een probeer opdwing.

(2) Hoe harder en meer star die botsingsmateriaal, hoe groter is die botsingskrag, $F$, en kleiner is die botsingstyd, $t$, en botsingspad, $s$.

(3) Hoe groter die kontakarea, hoe groter is die resulterende botsingskrag vir dieselfde starheid van materiaal.

(4) Hoe sagter en meer plasties die materiaal is, hoe groter word die kontakarea tydens botsing, maar die krag sal slegs toeneem indien die voertuie solied bly of word.

\subsection{Passasiersbeweging tydens 'n trompop botsing}

Wanneer 'n bewegende motor reg van voor teen 'n spoed van $50 \mathrm{~km} / \mathrm{h}$ met 'n soliede versperring soos 'n betonmuur bots, beweeg dit daarna nog 'n kort afstand van ongeveer een meter relatief tot die versperring vorentoe, terwyl die voorkant tussen die buffer en voorruit ( $\sim 30 \%$ van die motorlengte) ineengedruk word of opfrommel, om in minder as 'n tiende van 'n sekonde tot rus te kom. Soos figuur 33 toon, asook die dramatiese SABS-video, bly 'n passasier sonder sitplekgordel weens sy of haar traagheid aan die vorentoe beweeg oor 'n afstand van ongeveer ' $n$ halwe meter relatief tot die voertuig, totdat die liggaam die instrumentepaneel of voorruit tref. Hierdie sogenaamde "tweede botsing" kan ernstige beserings veroorsaak.

Soos figuur 31(a) toon, fluktueer die vertraging, d.w.s. negatiewe versnelling, om 'n gemiddelde $\bar{a}=\frac{\Delta v}{\Delta t} \sim \frac{14}{0.08}$ $=175 \mathrm{~m} / \mathrm{s}^{2}$ of $18 \mathrm{~g}$, wat volgens Newton se tweede be-

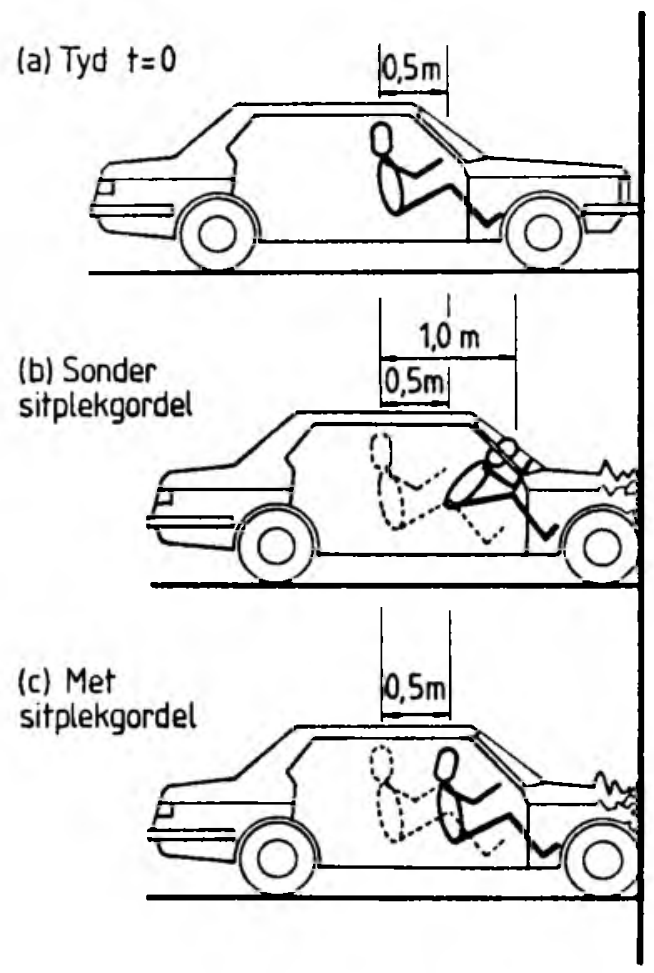

FIGUUR 33: Passasiersbeweging ( $p$ ) in 'n motor tydens trompop botsing teen ' $n$ soliede versperring $(v) .^{33}$ wegingswet 'n gemiddelde vertragingskrag $\bar{F}=m \bar{a} \sim 2$ $x 10^{5} \mathrm{~N}$ impliseer. Indien hierdie fluktuasies glad gemaak word, kan die versnellingskromme wiskundig benader word ${ }^{31}$ deur ' $n$ kwartsinusvormige golf

$$
a(t)=-a_{0} \sin \omega t .
$$

ierin is $a_{\mathrm{o}}$ die maksimum waarde of amplitude ( $\sim 30 \mathrm{~g}$ in voorbeeld) en

$$
\omega=2 \pi f=\frac{2 \pi}{T}
$$

die hoekfrekwensie ( $~ 20 / \mathrm{s}$ in voorbeeld), bepaalbaar uit die periode wat vier keer so lank as die totale botsingstyd is. Deur grafies die area onder die $a-t$ grafiek kumulatief oor agtereenvolgende tydintervalle te bepaal of direk deur integraalrekene, volg die spoed tydens 'n botsing as 'n funksie van die tyd:

$$
v(t)=\int a \mathrm{~d} t=\frac{a_{0}}{\omega} \cos \omega t,
$$

met 'n grafiese voorbeeld in figuur 31(b) getoon. Op soortgelyke wyse vanaf die $v-t$ grafiek volg ook die afstand as 'n funksie van die tyd

$$
s(t)=\int v \mathrm{~d} t=\frac{a_{0}}{\omega^{2}} \sin \omega t,
$$

met 'n grafiese voorbeeld in figuur 31(c) getoon. Uit (92) en (95) volg dat die versnelling regeweredig met die verplasing, maar in die teenoorgestelde rigting (minusteken) volgens

$$
a=-\omega^{2} s
$$

varieer. Volgens Newton se tweede bewegingswet is die krag

$$
F=m a=-m \omega^{2} s=-k x,
$$

met kragkonstante, $k=m \omega^{2}\left(\sim 4 \times 10^{5} \mathrm{~N} / \mathrm{m}\right.$ in voorbeeld), tiperend van 'n eenvoudige harmoniese ossillator soos 'n puntmassa aan 'n vibrerende elastiese veer. Die krag op die ineenstortende metaalromp is dus nie konstant nie, maar neem baie benaderd regeweredig met die hoeveelheid vervorming toe, soos grafies in figuur 30 aangedui. In geval (b) word onderskei tussen 'n dinamiese geval van 'n voertuig wat 'n hoogte $h$ gelykstaande aan 'n bepaalde botsingspoed $v$ volgens (91) bokant die grond opgehys en te pletter laat val word, en 'n statiese geval van hidrouliese saampersing van 'n motorwrak tot metaalafval op 'n skrootwerf. Sowel figuur 30(a) as (b) vertoon impulsiewe momentumfluktuasies, $\Delta p=F \Delta t$, te wyte aan die "sterk" massiewe onderdele soos die enjin en transmissie, wat nie opfrommel nie en aansienlik met die botsingspoed varieer. Aangesien, soos reeds in afd. 6.2 genoem, die kragwet nie eenvoudig volgens Hooke s'n (97) daar uitsien nie, verteenwoordig bogenoemde teoretiese model slegs 'n gerieflike maar growwe benadering van 'n trompop botsing met 'n soliede versperring. Weens die permanente vervorming wat plaasvind, is die algemene ossillatoriese aard in elk geval baie kortstondig.

\subsection{Verband tussen voertuigskade en passasiersbesering: sitplekgordels}

Figuur 34(a) toon dat die meeste skade vroeg tydens die botsingsproses plaasvind, terwyl die voorwaartse beweging van die passasiers baie stadig ontwikkel. Na ongeveer die helfte van die botsingstyd het die passasierskajuit reeds $80 \%$, maar die insittendes self slegs $20 \%$, van hulle totale voorwaartse beweging voltooi. Dit impliseer dat 'n insittende sonder sitplekgordel die voorkant van die kajuit teen 'n hoë spoed tref, soos afleibaar is uit die gradiënt van die 

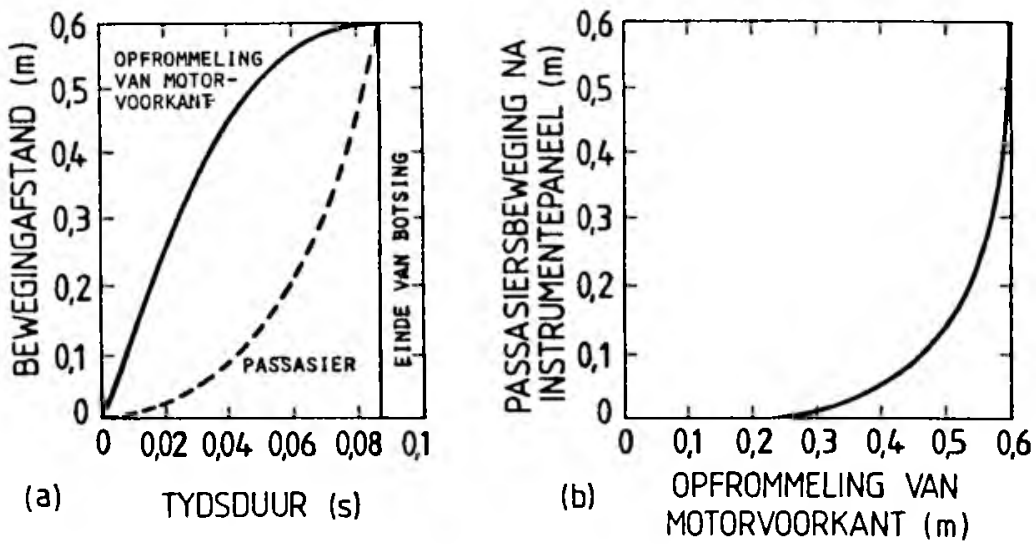

FIGUUR 34: Die beweging van die passasierskajuit en insittendes as funksie van (a) die tydsduur, en (b) mekaar, tydens 'n trompop botsing teen $50 \mathrm{~km} / \mathrm{h}$ met ' $\mathrm{n}$ soliede versperring. ${ }^{3 l}$

TABEL 4

Botsingsafstande en -vertragings vir verskillende voorwerpe in die passasierskajuit tydens vervorming as gevolg van 'n trompop botsing van $50 \mathrm{~km} / \mathrm{h}$ teen 'n soliede versperring ${ }^{3 \mathrm{l}}$

\begin{tabular}{|l|c|c|c|c|c|}
\hline Botsingsvoorwerp & $\begin{array}{c}\text { Oorspronklike } \\
\text { passasiers- } \\
\text { afstand } \\
(\mathrm{m})\end{array}$ & $\begin{array}{c}\text { Voorwerp- } \\
\text { vervorming }\end{array}$ & $\begin{array}{c}\text { Verdere } \\
\text { kajuit- } \\
\text { verplasing } \\
(\mathrm{m})\end{array}$ & $\begin{array}{c}\text { Totale } \\
\text { stopafstand } \\
\text { vir passasier } \\
(\mathrm{m})\end{array}$ & $\begin{array}{c}\text { Relatiewe } \\
\text { passasiers- } \\
\text { vertraging } \\
\left(\frac{a}{g}\right)\end{array}$ \\
\hline Voorruit & 0,4 & 0,025 & 0,005 & 0,030 & 333 \\
Instrumentepaneel & 0,4 & 0,15 & 0,005 & 0,155 & 65 \\
Stuurwiel & 0,25 & 0,25 & 0,03 & 0,28 & 36 \\
Sitplekgordel & 0,025 & $\begin{array}{c}0,30 \\
\text { (speling) }\end{array}$ & 0,28 & 0,58 & 17 \\
\hline
\end{tabular}

relevante kromme, bv. $15 \mathrm{~m} / \mathrm{s}$ of $54 \mathrm{~km} / \mathrm{h}$ teen die voorruit op 'n afsand van $0,40 \mathrm{~m}$. Die gevolge van hierdie "tweede botsing" vir die passasier, hang af van die botsingspoed, die massa van die passasier en die tipe voorwerp wat in die kajuit getref word, bv. die voorruit, instrumentepaneel, stuurwiel of sitplekgordel. Die afstand waaroor die vertragingskrag uitgeoefen word, bestaan uit twee gedeeltes, $\mathrm{nl}$. die vervorming van die voorwerp wat getref word en die verdere verplasing van die passasierskajuit (= verdere opfrommeling van die voertuig). Waardes hiervoor asook vir die gemiddelde vertraging bereken volgens $\bar{a}=\frac{v^{2}}{2 \mathrm{~s}}$ vir die betrokke botsingspoed, word in tabel 4 vir bogenoemde teikenvoorwerpe aangedui. Van bo na onder volg daaruit dat hoe groter die vervorming van die teikenvoorwerp en hoe langer die totale stopafstand van die insittende tydens 'n botsing is, hoe kleiner is die gemiddelde vertraging en dus die destruktiewe krag wat die passasier ondervind. Die veiligheidsvoordeel van sitplekgordels blyk duidelik aan die onderkant van hierdie tabel.

Alhoewel dieselfde hoeveelheid voertuigmomentum uitgewis moet word, ongeag of die instrumentepaneel of sitplekgordel tydens botsing die kragimpuls aan die insittende oordra, word die destruktiewe krag afgeskaal deur dit oor 'n langer tyd te laat werk tydens elastiese vervorming van 'n sitplekgordel. 'n Vasgegorde passasier kom tot rus terwyl die voorkant van die botsingsvoertuig opfrommel, maar 'n ongegorde passasier beweeg eers na die opfrommeling vorentoe en het dus ' $n$ baie korter stoptyd. Voorts word beserings nie deur die krag as sodanig bepaal nie, maar deur die krag per eenheidsarea uitgeoefen, oftewel die drukspan- ning, $p=\frac{F}{A}$. Laasgenoemde is groot wanneer'n skedel die skerp rand van die instrumentepaneel tref, maar klein vir die geval van gordelbande om die maag en oor die skouer. Figuur 30(c) toon voorbeelde van spanning-vervormingskrommes vir sitplekgordels. Afgesien van die versagting van die "tweede botsing" hou sitplekgordels ook die passasiers in posisie, as 'n vaste komponent van die voertuig tydens skielike versnellings, teen afdraande, om draaie, ens. Dit maak die reis dus minder liggaanssvermociend en verhoed ook dat die insittendes tydens botsings met ernstige gevolge uit hulle voertuie geslinger word. Die effektiwiteit van 'n sitplekgordel, nl. die relatiewe afname in sterftes indien diegene wat dit nie gebruik nie, dit wel sou doen, is uit empiriese gegewens in die VSA bereken ${ }^{34}$ as $42 \%$ vir bestuurders en $39 \%$ vir die voorste passasiers. In die VK het die sterftesyfer met $17 \%$ gekrimp vanaf 1982 tot 1983 toe die gebruik verpligtend geword het. ${ }^{35}$ Nieteenstaande hierdie wetenskaplik bewese voordele gordel slegs sowat $61 \%$ van motoriste in die RSA ter aanvang van 'n rit vas. ${ }^{36}$

6.4 Fisiologiese effek van kortstondige, hoë versnellings Tabel 5 vergelyk versnellings wat in bewegende motorvoertuie ondervind word, met dié van ritte in ' $n$ hysbak of vliegtuig. Passasiersbesering is die kumulatiewe effek van 'n reeks aparte beserings aan verskillende liggaamsdele (oppervlak, skelet, inwendige organe en brein) wanneer beskadigde voertuigdele die liggaam bereik, of die liggaam daarteen geslinger word. Die graad van besering word deur die massa en grootte van die liggaamsdele en voertuigkom- 
ponente, die weerstand wat laasgenoemde bied, asook hul relatiewe spoed hepaal. Die toleransiegrens tussen ligte en ernstige beserings, veral van die kop, oor die volle $0,1 \mathrm{~s}$ tydsduur van 'n trompop botsing, kan konserwatief op $45 \mathrm{~g}$ gestel word. Groter versnellings van korter duur is egter ook oorleefbaar soos figuur 35 toon. Sodanige limietversnelling impliseer volgens Newton se tweede bewegingswet, $F=m a$, dat 'n insittende met 'n massa van $50-75 \mathrm{~kg}$ aan 'n gemiddelde krag van 22-33 kN onderwerp word. Hoe kleiner die area waaroor die krag uitgeoefen word, hoe gevaarliker is dit. Die drukspanningstoleransie beloop $3,5 \times 10^{5} \mathrm{~Pa}$ of benaderd 3,5 atmosfere, bv. 'n krag van 7 $\mathrm{kN}$ wat oor ' $\mathrm{n}$ area van $0,02 \mathrm{~m}^{2}$ uitgeoefen word in die geval van 'n effektiewe sitplekgordel.

TABEL 5

Grootte en tydsduur van kortstondige versnellings waaraan die mens onderwerp word ${ }^{37}$

\begin{tabular}{|c|c|c|}
\hline Tipe versnelling & $\begin{array}{c}\text { Grootte relatief tot } \\
\text { gravitasie }\left(\frac{a}{g}\right)\end{array}$ & $\begin{array}{c}\text { Tydsduur } \\
\text { (s) }\end{array}$ \\
\hline $\begin{array}{l}\text { Hysbak } \\
\text { Motorvoertuie: }\end{array}$ & $0,1-2,5$ & $1-5$ \\
\hline Gemaklike stilhou & 0,25 & $5-8$ \\
\hline Ongemaklike stilhou & 0,45 & $3-5$ \\
\hline Noodremming & 0,75 & 3 \\
\hline $\begin{array}{l}\text { Botsing } \\
\text { (moontlike oorlewing) }\end{array}$ & $20-100$ & $\leq 0,1$ \\
\hline Vliegtuie: & & \\
\hline Normale opstyg & 0,5 & $10-20$ \\
\hline $\begin{array}{l}\text { Pendeltuigopstyg } \\
\text { (met aanjaagvuurpyle) }\end{array}$ & 1,25 & 120 \\
\hline Katapultopstyg & $2,5-6$ & 1,5 \\
\hline Uitskietstoel & $10-15$ & 0,25 \\
\hline Valskerm: oopgaan & $8-33$ & $0,2-0,5$ \\
\hline Valskerm: landing & $3-4$ & $0,1-0,2$ \\
\hline $\begin{array}{l}\text { Botsing: landing } \\
\text { (moontlike oorlewing) }\end{array}$ & $20-100$ & \\
\hline
\end{tabular}

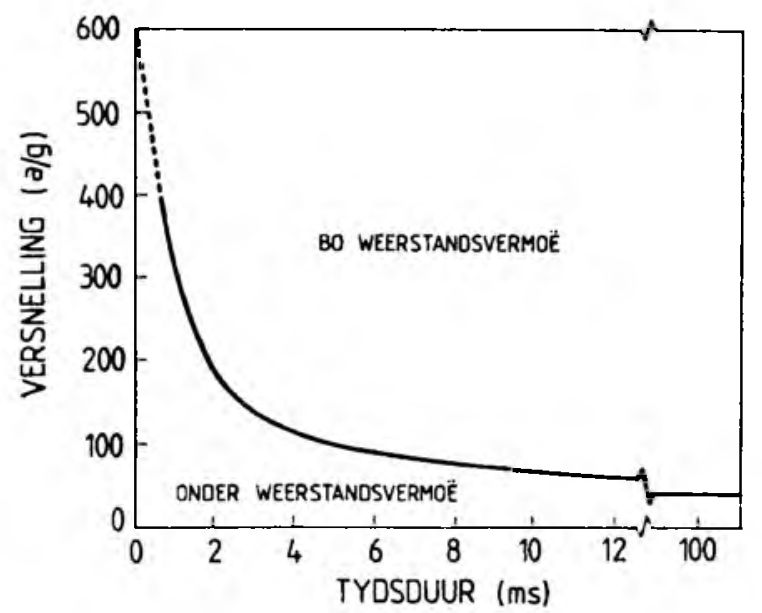

FIGUUR 35: Harsingskudding-toleransiekromme van die Wayne Staatsuniversiteit, wat die weerstandsvermoë aandui van die menslike brein tydens botsing van die voorkop teen 'n starre, plat oppervlak. ${ }^{28}$

\section{VEILIGHEIDSONTWERP}

Dic moderne tegnologie word al hoe meer aangewend om die koppeling tussen voertuig, pad en bestuurder hegter en veiliger te maak.

\subsection{Voertuig}

Basies vereis die fisika dat ' $\mathrm{n}$ bepaalde hoeveclheid momentum (van dic orde $10^{4} \mathrm{~kg} \mathrm{~m} / \mathrm{s}$ ) en bewegingsenergie $\left(10^{4-}\right.$ $10^{6} \mathrm{~J}$ ) tydens 'n botsing geabsorbeer moet word volgens die twee beginsels:

verandering in momentum $=$ krag x stoptyd; en verandering in bewegingsenergie $=\mathrm{krag} x$ stopafstand.

Die groot, skadelike botsingskrag kan dus verswak word deur die stopafstand en -tyd te verleng. Voorts is dit belangrik om die krag oor so 'n groot moontlike oppervlak te versprei en dus die drukspanning te verminder, terwyl vervaardiging uit "sterker" materiaal met groter elastisiteit ook nodig is. Konstruksie van 'n "veilige" voertuig behels basies voor- en agtergedeeltes wat maklik tydens botsing ineenstort, nl. sogenaamde opfrommelgebiede. Die sentrale passasierskajuit moet versterk wees om ongeskonde behoue te bly en stadiger vertraag te word tydens ' $n$ botsing. Kruisstutte aan die voorkant, heuningkoekpanele op die sye en in die dak en skuins afskermingsplate van aluminium en glasvesel tussen die enjin en passasierskajuit word reeds aangebring sonder om die voertuigmassa drasties te vermeerder. Verbeterings om die botsingskrag wyer te versprei sodat gesigs- en kopbeserings drasties beperk word, behels die vermindering van uitstaande projeksies soos handvatsels en knoppe binne en buite die stuurkajuit, vermeerdering van die stoffeerwerk op die paneelbord, 'n saggekussingde stuurwiel (soos dié van British TRRL en Sheller maatskappy), ${ }^{39}$ driepuntsitplekgordels en kopstutte (om die retrofleksiewe swiepslag te beperk). 'n Nuwe toevoeging is die lugsak wat uit die stuurkolom skiet en opblaas, om as 'n buffer tussen die bestuurder en voorruit te dien. ${ }^{40}$

Veral teen 'n lae botsingspoed $(<20 \mathrm{~km} / \mathrm{h}) \mathrm{kan}$ die elastisiteitsperk gerek word om motorskade heeltemal uit te skakel deur die gebruik van groter en dikker buffers, of buffers voorsien van vloeistofgevulde slagdempers ("dashpots"), soos in figuur $36 .^{32}$ In laasgenoemde geval forseer die botsingskrag die vloeistof deur klein gaatjies om die bewegingsenergie geleidelik te absorbeer. Twee sulke slagdempers met byvoorbeeld 'n lengte van $150 \mathrm{~mm}$ en 'n deursnee van $75 \mathrm{~mm}$ elk sal 'n druk wat 'n faktor $\frac{A_{1}}{A_{2}}=16$ keer hoër is as dié van 'n paar atmosfere, oor die hele buffer met tipiese $100 \mathrm{~mm}$ x 1,4 m-afmetings, moet kan weerstaan. Die temperatuur van die vloeistof self sal baie effens styg, naamlik minder as 'n graad Celsius in die geval van water. 'n Plaaslike ontwikkeling ${ }^{41}$ is die Underrun Protection System, wat bestaan uit sterk bufferstaafarms onder die bakwerk van swaar vragvoertuie met 'n hoë agterkant. Dit verhoed dat kleiner voertuie wat van agter daarteen bots, onder die staalbak injaag sodat hulle dakke afgestroop en die insittendes onthoof word.

Metodes wat tans ontwikkel word om die ry- en bestuursvermoë van voertuie te verbeter, sluit in vierwielaandrywing, vierwielstuurvermoë, aktiewe vering, teenglyremen sporingskontrolestelsels. Die ABS/TCS-stelsel van die Duitse Teves-maatskappy gebruik mikro-elektroniese prosesseerders om die hidrouliese remvloeistofdruk op elke 
wiel te monitor en te verstel, sodat dic voertuig tydens 'n noodstop in 'n reguitlyn bly voortbeweeg, selfs onder uiterste padtoestande. ${ }^{42}$

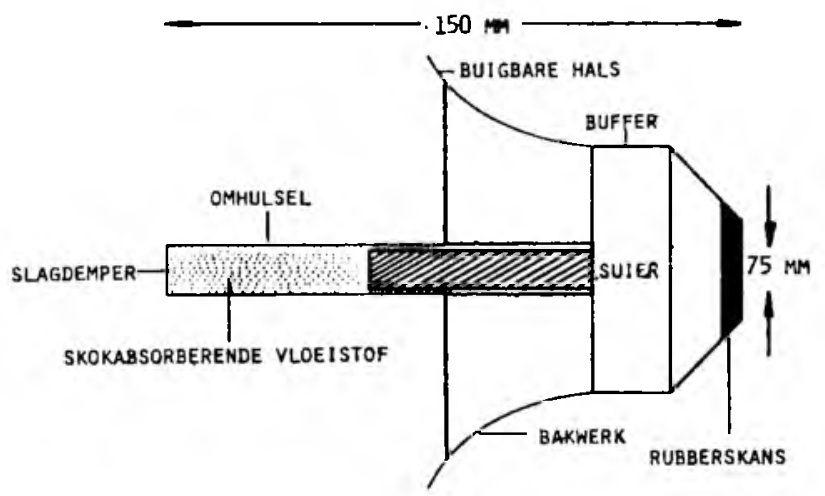

FIGUUR 36: Voertuighuffer met slagdemper vir groter veiligheid tydens botsing. ${ }^{32}$

\subsection{Die pad en verkeersowerhede}

Miljoene rande word jaarliks bestee om die $182677 \mathrm{~km}$ nasionale en provinsiale RSA-paaie asook munisipale strate te verbeter en te beveilig. Deurpaaie met multibane in dieselfde rigting vir veiliger verbysteek, asook op- en afritte wat regsdraai by T-aansluitings heeltemal uitskakel, word by digbevolkte stedelike gebiede voorsien. Munisipale en sentrale databanke word opgebou om gevaarpunte op stedelike en plattelandse roetes te identifiseer. Voor gevaarlike T-aansluitings word geraasstroke in die padoppervlak aangebring, terwyl skerp draaie deur botswerings ${ }^{31}$ van sterk gegolfde staalstroke voorsien word. Sommige oorsese hoofweë beskik oor oorhoofse veseloptiese stelsels met inligting oor pad-, weer- en verkeerstoestande wat verderaan heers. Verkeersligte kan outomaties gefaseer en gesinchroniseer word, om verkeer gladder te laat vloei en tyd en brandstof te bespaar. Verkeersowerhede rig slagspreuke, pleidooie, advertensieveldtogte, ens. tot die publiek en gebruik patrollies, blokkades, helikopters ("eye in the sky") en versteekte kameras om die padgebruiker meer veiligheidsbewus te maak.

\subsection{Die menslike faktor}

Die motorvoertuig is ' $n$ hoogs tegnologiese bewegingsmasjien, wat korrekte en vroegtydige gebruik van sy stelsels van kontroles onder ' $n$ verskeidenheid van padtoestande en verkeersituasies vereis. Die menslike skakel in die voertuigbestuursproses word in tabel 6 uiteengesit. Dit vereis tot soveel as 14 handelinge vir 'n enkele prosedure soos om regs te draai by 'n straatkruising (kyk na tabel 7). In die hande van 'n onervare, feilbare mens ontaard die motor dikwels in 'n gevaarlike monster.

Elementêre riglyne vir bestuurders verg die volgende: gereelde instandhouding van 'n voertuig in 'n padwaardige toestand; nie te bestuur onder die invloed van alkohol of verdowingsmiddels nie; vas te gordel; voortdurende bedagsaamheid veral ten opsigte van gevaarlike hindernisse op die pad, verkeersaansluitings, rigtingveranderings en die padtoestand; gehoorsaamheid aan verkeersreëls en padtekens; aanpassing van die spoed by veranderende omstandighede; handhawing van korrekte volgafstande (die 2 sckonde reël); links te hou en regs verby te steck; ens. Dic botsingsrisiko kan ook verlaag word deur indien noontlik minder te ry en die reistyd te kies sodat dit nie binne spitsverkeer val nie.

TABEL 6

Skematiese uiteensetting van menslike betrokkenheid by voertuigbestuur
Bestuursfunksie

Waarneming van vorms en beweging

Verwerking van inligting
$\downarrow$
Skatting van grootte,
afstand, rigting en spoed
van voorwerpe
$\downarrow$
Besluit hoe on op te tree

$\downarrow$

Handeling: stuur, rem of versnel
Menslike organe betrokke Oë en ore

Bewustelike verstand (brein)

Hande en voete
TABEL 7

Voorbeeld van opeenvolgende bestuurderaksies wanneer by 'n straatkruising regs gedraai word"

1. Gaan truspieëls en blindekolle regs na.

2. Sein die voorneme om regs te draai.

3. Gehoorsaam die verkeerstekens, -seine en -merke.

4. Stuur na, en posisioneer die voertuig in die toepaslike baan, indien nodig.

5. Verminder spoed, indien nodig.

6. Rem, indien nodig.

7. Gee toe aan naderende verkeer en/of voetgangers.

8. Stop indien nodig (verseker dat die wicle indien moontlik of waar toepaslik reguit is).

9. Skakel rat, indien nodig.

10. Trek weg of ry aan.

11. Gaan die truspieëls of blindekolle regs na.

12. Stuur na die toepaslike baan en gehoorsaam verkeerstekens, -seine en -merke.

13. Versnel soos nodig.

14. Kanselleer die sein.

Huidige ontwikkeling maak van mikro-clektronika, telekommunikasie en informasietegnologie gebruik om die ontoereikende sintuiglike waarneming en verstandelike sintese van die menslike bestuurder aan te vul, en selfs oor te neem, indien nodig. ' $n$ Kunsmatige intelligensiesisteem getiteld Programme for a European Traffic with Higher Efficiency and Unprecedented Safery (PROMETHEUS) ${ }^{43}$ word tans in Europa uit rekenaars in motors, patrollichelikopters en sensors op straathoeke opgebou. Dit kan bestuurders 'n lewensbelangrike halwe sekonde vroeër waarsku wanneer ander voertuie om 'n blinde draai, by 'n kruising, in donkerte of mis, of buite die gesigveld na hulle op pad is. As 'n tweede fase kan 'n outomatiese noodak- 
siesisteem ook toegevoeg word, om die vermydingsaksie (rem en stuur) by 'n feilbare bestuurder in 'n botsingsituasie oor te neem. 'n Prototipe radarkontrole- en waarskuwingstelsel oor volgafstande tussen motors is ook reeds ontwikkel. Stemuittree-intree-kontroles, oudiowaarskuwingseine, skynvertonings agterin of bokant die instrumentepaneel, nagbestuur- en navigasiehulpmiddels word reeds uitgetoets. Dit sal die bestuurder se laterale rigting van en longitudinale kontrole oor die voertuig vergemaklik, sonder om die aandag te veel van die voorwaartse visie af te trek en die hande van die stuurwiel af te haal. ${ }^{44}$

\section{SLOTSOM}

Bogenoemde wetenskaplike kennis kan hopelik help dat die jeugdige, onervare bestuurder (18-24-jarige ouderdomsgroep) sy potensieel gevaarlike masjien met groter ontsag sal beheer, maar is nie voldoende nie. Voornemende bestuurders behoort van kleins af opgevoed te word tot die korrekte ingesteldheid as padgebruikers, nl. dat dit 'n voorreg en nie 'n reg is nie, wat met medebestuurders gedeel moet word..$^{45} 46$ Elke landsburger se persoonlike betrokkenheid by verkeersveiligheid word verwoord in die NVVR se slagspreuk: "Kyk. Dink. En bly Leef?"

\section{LITERATUURVERWYSINGS}

1. NRSC (1987). Speed - What is the solution? Robot, 4, 4-5.

2. NRSC (1988). Highways and the traffic engineer, Robot, 4, 25-26.

3. NRSC (1988). Motor vehicle collisions - a leading cause of death in USA, Robot, 6, 28.

4. Pienaar, I. \& Upton, A.H. (1986). Nasionale ongeluksteekproefstelsel (NOSS): Finale verslag NVVR/16, NIVP, WNNR.

5. NRSC (1988). Traffic collisions: Human failure the main cause, Robot, 3, 26.

6. NVVR (1987). 'n Nuwe benadering tot verkeersveiligheid: Sê "Botsing", nie "Ongeluk" nie!, Robot, 3, 14.

7. Quass, FW. (1988). Hoë spoed: Die moordenaar op ons paaie, Robot, $4,30-31$.

8. NRSC (1985). The two second rule, Robot, 2, 6-7.

9. NVVR (1987). Volgafstand - jou leefruimte, Robot, 3, 4-5.

10. NVVR (1988). Volgafstand vs stopafstand, Robot, 7, 13-15, 27.

11. NRSC (1990). The sad truth about rear-end collisions, Robot, 3, 3-4.

12. Raybestes-Belacco tabelle in KPA Verkeersordonnansie.

13. Saayman, R. (1988). Die motorkar as voertuig om basiese meganikakennis oor te dra, Deel 1, Spectrum, 26, 4, 18-24; Deel II, Spectrum $27,1,23-27$

14. Watts, J.F. (1981). To stop or not to stop - kinematics and the yellow light, The Physics Teacher, 2, 114-115.
15. Easton, D. (1987). The stoplight dilemma revisited, The Physics Teacher, 1, 36-37.

16. De Koker, E. \& Tomecki, A.B. (1986). Pretoria se verkeersreëlings, Robot, 1, 20-21.

17. Reizes, H. (1973). The Mechanics of Vehicle Collisions (Charles C. Thomas, Springfield, 1ll.).

18. Brake, Mary L. (1981). Physics in accident investigations, The Physics Teacher, 1, 26-29.

19. Tao, P.K. (1987). Traffic accident investigation: a suitable theme for teaching mechanics, Physics Education, 22, 284-291.

20. Baker, J.S. (1975). Traffic Accident Investigation Manual (Traffic Institute, Northwestern University).

21. Rivers, R.H. (1980). Traffic Accident Investigators' Handbook (Charles C. Thomas, Springfield, III.).

22. Byatt, R. \& Watts, R. $(1980,1981)$. Traffic Accident Investigation Manual, Vol. 1 and 2 (Pitman, London).

23. Saayman, R. (1983). Fisika in die pretpark, Spectrum, 21, 3, 25-30.

24. Dugmore, B. (1987). Recommendations for advanced driving, parts 5 and 6, Robot, 3, 20-21; 4, 20-21

25. Dugmore, B. (1988). Recommendations for advanced driving, parts 10 and 11, Robot, 2, 22-23; 3, 20-21.

26. NVVR (1985). Bestuurswenke: Draaie, Robot, 2, 18-19.

27. Collins, J.C. (1979). Accident Reconstruction (Charles C. Thomas, Springfield, III)

28. Damask, A.C. (1987). Forensic physics of vehicle accidents, Physics Today, 3, 36-80.

29. Knight, P. (1975). The physics of traffic accidents, Physics Education, 10, 30-35.

30. Richter, B. (1984). Entwicklung von PKW im Hinblick auf einen volkswirtschaflich optimalen Insassen Schutz (Volkswagen AG, Wolfsburg).

31. Kelly, D.T. (1974). Dynamics, Engineering Science Project of Schools Council/Loughborough University of Technology (MacMillan Education Lid, London)

32. Strassenburg. A.A. \& Impeduglia, G. (1974). Automobile Collisions, Physics of Technology Module on Energy and Momentum (The America Institute of Physics, SUNY, Binghamton).

33. Advanced Physics Project for Independent Learning (1978). Forces and Motion (John Murray, London).

34. Evans, L. (1988). The Science of Traffic Safety, The Physics Teacher, October, 426-431.

35. Neilson, I.D. (1986). Impact and injury in Car Accidents, Phys. Technol., 17, 62-68.

36. NVVR (1989). Net die wyses gespe vas, Robot, 4, 3-5.

37. Goldman, D.E. \& Von Gierke, H.E. (1961). In Shock and Vibration Handbook, Harris and Crede (eds.), Chapter 44 (McGraw-Hill, New York).

38. NVVR (1987). Nuwe bestuurderstoets spreek kernprobleme aan, Robot, 5, 18-19.

39. NRSC (1989). Toward the ultimate steering wheel, Robot, 1, 30-31.

40. NVVR (1990). Kussing tussen lewe en dood, Robot, 5, 9.

41. NRSC (1987). Death-trap for motorists averted, Robot, 5, 14-15.

42. NRSC (1987). Braking systems move into the electronic age, Robot. 3, 22-24.

43. NRSC (1987). Project Prometheus: Europe's high-tech road safety plan, Robot, 6, 20-21.

44. NRSC (1989). The human factor and technology, Robot, 4, 20-21; $5,20-21 ; 6,24-25$.

45. Smit, S.J. (1990). Ry veilig met 'n ander houding, Robot, 1, 28-29.

46. Maree, D.J.F. (1990). Die padgebruiker se ingesteldheid, Robot, 3, 18-19. 